\title{
Mycosphere notes 325-344 - Novel species and records of fungal taxa from around the world
}
Hyde $\mathrm{KD}^{1,2,3,4}$, Suwannarach $\mathrm{N}^{3,4 *}$, Jayawardena $\mathrm{RS}^{2,5}$, Manawasinghe $\mathbf{I S}^{\mathbf{1}}$, Liao $\mathrm{CF}^{1,2}$, Doilom $\mathrm{M}^{1}$, Cai $\mathbf{L}^{6}$, Zhao $\mathbf{P}^{6}$, Buyck $\mathrm{B}^{7}$, Phukhamsakda $\mathrm{C}^{8,9}$, Su WX ${ }^{8,9}$, Fu YP ${ }^{8,9}$, Li $Y^{8,9}$, Zhao $\mathrm{RL}^{6,11}$, He $\mathrm{MQ}^{6}$, Li JX ${ }^{6}$, Tibpromma $\mathrm{S}^{13,14}$, Lu $\mathrm{L}^{2,5,13,14}$, Tang $\mathrm{X}^{2,15}$, Kang $\mathrm{JC}^{15}$, Ren $\mathbf{G C}^{2,13}$, Gui $\mathbf{H}^{12}$, Hofstetter $\mathrm{V}^{16}$, Ryoo $\mathbf{R}^{17}$, Antonín $\mathbf{V}^{18}$, Hurdeal $\mathbf{V G}^{2,5}$, Gentekaki $\mathbf{E}^{2,5}$, Zhang $\mathrm{JY}^{2,19}$, Lu $\mathbf{Y Z}^{19}$, Senanayake IC ${ }^{1}$, Yu FM ${ }^{2,12}$, Zhao $Q^{12}$ and Bao $\mathrm{DF}^{2,10,20}$

\footnotetext{
${ }^{1}$ Innovative Institute for Plant Health, Zhongkai University of Agriculture and Engineering, Haizhu District, Guangzhou 510225, China

${ }^{2}$ Center of Excellence in Fungal Research, Mae Fah Luang University, Chiang Rai 57100, Thailand

${ }^{3}$ Research Center of Microbial Diversity and Sustainable Utilization, Faculty of Science, Chiang Mai University 50200, Chiang Mai, Thailand

${ }^{4}$ Department of Biology, Faculty of Science, Chiang Mai University, Chiang Mai 50200, Thailand

${ }^{5}$ School of Science, Mae Fah Luang University, Chiang Rai, 57100, Thailand

${ }^{6}$ State Key Laboratory of Mycology, Institute of Microbiology, Chinese Academy of Sciences, Beijing, 100101, China

${ }^{7}$ Institut de Systématique, Evolution, Biodiversité (ISYEB), Muséum national d'Histoire naturelle, CNRS, Sorbonne Université, EPHE, Université des Antilles, CP 39, 57 rue Cuvier, 75005 Paris, France

${ }^{8}$ Institute of Plant Protection, College of Agriculture, Jilin Agricultural University, Changchun 130118, China

${ }^{9}$ Engineering Research Center of Edible and Medicinal Fungi, Ministry of Education, Jilin Agricultural University, Changchun, Jilin, China

${ }^{10}$ Department of Entomology and Plant Pathology, Faculty of Agriculture, Chiang Mai University, Chiang Mai 50200, Thailand

${ }^{11}$ College of Life Science, University of Chinese Academy of Sciences, Beijing 100049, China

${ }^{12}$ Key Laboratory for Plant Diversity and Biogeography of East Asia, Kunming Institute of Botany, Chinese Academy of Sciences, Kunming 650201, Yunnan, China

${ }^{13}$ CIFOR-ICRAF China Country Program, World Agroforestry Centre, Kunming 650201, Yunnan, China

${ }^{14}$ Centre for Mountain Futures, Kunming Institute of Botany, Kunming 650201, Yunnan, China

${ }^{15}$ Engineering and Research Center for Southwest Biopharmaceutical Resource of National Education Ministry of China, Guizhou University, Guiyang 550025, Guizhou, China

${ }^{16}$ Département fédéral de l'économie, de la formation et de la recherche DEFR, Agroscope Domaine de recherche Protection des végétaux, Route de Duillier 60, CP 1012, 1260 Nyon 1, Switzerland

${ }^{17}$ Department of Forest Bioresources, National Institute of Forest Science, Suwon 16631, Republic of Korea

${ }^{18}$ Department of Botany, Moravian Museum, Zelný trh 6, CZ-659 37 Brno, Czech Republic

${ }^{19}$ School of Food and Pharmaceutical Engineering, Guizhou Institute of Technology, Guiyang 550003, China

${ }^{20}$ College of Agriculture and Biological Sciences, Dali University, Dali 671003, Yunnan, China
}

Hyde KD, Suwannarach N, Jayawardena RS, Manawasinghe IS, Liao CF, Doilom M, Cai L, Zhao P, Buyck B, Phukhamsakda C, Su WX, Fu YP, Li Y, Zhao RL, He MQ, Li JX, Tibpromma S, Lu L, Tang X, Kang JC, Ren GC, Gui H, Hofstetter V, Ryoo R, Antonín V, Hurdeal VG, Gentikaki E, Zhang JY, Lu YZ, Senanayake IC, Yu FM, Zhao Q, Bao DF 2021 - Mycosphere notes 325-344 - Novel species and records of fungal taxa from around the world. Mycosphere 12(1), 1101-1156, Doi 10.5943/mycosphere/12/1/14

\section{Abstract}

Fungi have a worldwide distribution, however, less than $10 \%$ of the estimated species have 
been described. This paper introduces Neolentithecia (Lentitheciaceae) as a new genus, 18 new species and one new host record based on morphological characteristics and phylogenetic analyses. The new species are Cantharellus hongneungensis (Hydnaceae), Cronartium armandii (Cronartiaceae), Dictyocephalos xinjiangensis (Phelloriniaceae), Distoseptispora chinensis, Distoseptispora guizhouensis (Distoseptisporaceae), Halobyssothecium thailandica, Neolentithecia changchunensis (Lentitheciaceae), Herpotrichia xiaokongense (Melanommataceae), Hymenopleella agaves, Synnemapestaloides shangrilaensis (Sporocadaceae), Hypsostroma thailandicum (Hypsostromataceae), Mucor phayaoensis, Mucor takensis (Mucoraceae), Neospadicoides bambusicola (Xenospadicoidaceae), Phellorinia longistriatica (Phelloriniaceae), Pseudocapulatispora fragrantis (Lophiostomataceae) and Tarzetta linzhiensis and Tarzetta confusa (Tarzettaceae). Additionally, a new host record is provided for Phragmocephala garethjonesii (Pleurotheciaceae). All taxa are described and illustrated. Trees are presented to show their phylogenetic placements.

Keywords - 19 new taxa - Agaricomycetes - Dothideomycetes - Mucoromycetes Pezizomycetes - Phylogeny - Pucciniomycetes - Sordariomycetes - Taxonomy

\section{Table of contents}

Ascomycota R.H. Whittaker

Dothideomycetes O.E. Erikss. \& Winka

Pleosporomycetidae C.L. Schoch, Spatafora, Crous \& Shoemaker

Pleosporales Luttrell ex M.E. Barr

Hypsostromataceae Huhndorf

Hypsostroma Huhndorf

325. Hypsostroma thailandicum J.Y Zhang, Y.Z. Lu \& K.D. Hyde, sp. nov.

Lentitheciaceae Y. Zhang ter, C.L. Schoch, J. Fourn., Crous \& K.D. Hyde

Halobyssothecium Dayar., E.B.G. Jones \& K.D. Hyde

326. Halobyssothecium thailandica D.F. Bao, Z.L. Luo, K.D. Hyde \& H.Y. Su, sp. nov.

327. Neolentithecia C. Phukhams., K.D. Hyde \& Y. Li, gen. nov.

328. Neolentithecia changchunensis C. Phukhams., K.D. Hyde, W.X. Su \& Y. Li, sp. nov.

Lophiostomataceae Luerss.

Pseudocapulatispora Mapook \& K.D. Hyde

329. Pseudocapulatispora fragrantis C.F. Liao \& Doilom, sp. nov.

Melanommataceae G. Winter

Herpotrichia Fuckel

330. Herpotrichia xiaokongense G.C. Ren \& K.D. Hyde, sp. nov.

Pleurotheciales Réblová \& Seifert

Pleurotheciaceae Réblová \& Seifert

Phragmocephala E.W. Mason \& S. Hughes

331. Phragmocephala garethjonesii H.Y. Su, Udayanga \& K.D. Hyde

Pezizomycetes O.E. Erikss. \& Winka

Pezizales J. Schröt.

Tarzettaceae Ekanayaka, K.D. Hyde, Q. Zhao \& E.B.G. Jones

Tarzetta Ekanayaka, K.D. Hyde, Q. Zhao \& E.B.G. Jones

332. Tarzetta confusa F.M. Yu, S. Wang, Q. Zhao \& K.D. Hyde, sp. nov.

333. Tarzetta linzhiensis F.M. Yu, S. Wang, Q. Zhao \& K.D. Hyde, sp. nov. 
Sordariomycetes O.E. Erikss. \& Winka

Diaporthomycetidae I.C. Senan., Maharachch. \& K.D. Hyde

Distoseptisporales Z.L. Luo, K.D. Hyde \& H.Y. Su

Distoseptisporaceae K.D. Hyde \& McKenzie

Distoseptispora K.D. Hyde, McKenzie \& Maharachch.

334. Distoseptispora chinensis X. Tang, Jayaward., J.C. Kang \& K.D. Hyde, sp. nov.

335. Distoseptispora guizhouensis X. Tang, Jayaward., J.C. Kang \& K.D. Hyde, sp. nov.

Xenospadicoidales Hern.-Restr., J. Mena \& Gené

Xenospadicoidaceae Hern.-Restr., J. Mena \& Gené

Neospadicoides Z.L. Luo, K.D. Hyde \& H.Y. Su

336. Neospadicoides bambusicola J.Y. Zhang, Y.Z. Lu \& K.D. Hyde, sp. nov.

Xylariomycetidae O.E. Erikss. \& Winka

Sporocadaceae Corda

Hymenopleella Munk

337. Hymenopleella agaves I.C. Senan. \& K.D. Hyde, sp. nov.

Synnemapestaloides T. Handa \& Y. Harada

338. Synnemapestaloides shangrilaensis L. Lu \& S. Tibpromma, sp. nov.

Basidiomycota R.T. Moore

Agaricomycetes Doweld

Agaricomycetidae Locq.

Agaricales Underw.

Phelloriniaceae Doweld

Dictyocephalos Underw. ex V.S. White

339. Dictyocephalos xinjiangensis R.L. Zhao, M.Q. He \& J.X. Li, sp. nov.

Phellorinia Berk.

340. Phellorinia longistriatica R.L. Zhao, M.Q. He \& J.X. Li, sp. nov.

Cantharellales Gäum.

Hydnaceae Chevall.

Cantharellus Adans. ex Fr.

341. Cantharellus hongneungensis B. Buyck, R. Ryoo, V. Hofst. \& V. Antonín, sp. nov.

Pucciniomycetes R. Bauer, Begerow, J.P. Samp., M. Weiss \& Oberw.

Pucciniales Caruel

Cronartiaceae Dietel

Cronartium Fr.

342. Cronartium armandii X. Qi, P. Zhao \& L. Cai, sp. nov.

Mucoromycota Doweld

Mucoromycetes Doweld

Mucorales Dumort.

Mucoraceae Fr.

Mucor Fresen.

343. Mucor phayaoensis V.G. Hurdeal, E. Gentekaki \& K.D. Hyde, sp. nov.

344. Mucor takensis V.G. Hurdeal, E. Gentekaki \& K.D. Hyde, sp. nov.

\section{Introduction}

Classification of the fungi has proven challenging due to the small number of known as compared to estimated species and a lack of sequence data for many extant taxa (Taylor et al. 2006, 
Mindell 2013, Hyde et al. 2020a). Fungi are eukaryotic microorganisms that play key ecological roles as decomposers, mutualists, or pathogens (Hyde et al. 2007, Griffith et al. 2010, Lange 2014, Willis 2018, Rashmi et al. 2019). Fungi have huge biotechnological potential in future bioeconomies, in agriculture (biocontrol agents, biofertilizers and pathogens), industry (biofuel, beverages, cosmeceuticals, food), the environment (mycoremediation, nutrient cycling and waste valorization) and medical and pharmaceutical products (Willis 2018, Hyde et al. 2019b, Yadav 2019, Meyer et al. 2020). Therefore, their discovery is important and may serve a resource for human technologies and biotechnological research (Hyde et al. 2019a).

Despite their importance, the discovery and classification of fungi has proven difficult. It was realized that fungi belong to a separate kingdom, which diverged around one billion years ago (Baldauf \& Palmer 1993, Parfrey et al. 2011, Taylor et al. 2014). Traditionally, fungi were classified into five phyla Ascomycota, Basidiomycota, Chytridiomycota Glomeromycota and Zygomycota based on morphology, physiology, biochemistry, chemical tests and their life modes (Alexopoulos et al. 1996, Webster \& Weber 2007). However, the current classification based on a combination of morphology, life modes, distribution and genomic data have placed fungi into 19 phyla (Hibbett et al. 2007, Tedersoo et al. 2018, Wijayawardene et al. 2018, 2020).

Over two decades ago, the global fungi species number was conservatively estimated at 1.5 million, a figure which has since been regularly cited in the scientific literature (Hawksworth 1991). This estimate was based on extrapolations from several sets of independent data. This included the number of fungi vs. native plants growing in a particular region, the number of species on a cross-section of native plants in Europe and America and the number of species discovered in a particular alpine community. However, this estimate lacked data from the important regions of the tropics (Hawksworth 2001). Due to an increase in mycological studies in Asia and South America, numerous novel fungi have been discovered and around 100,000 species are now thought to be extant (Kirk et al. 2008, Hyde et al. 2020a). The estimate of species has been revised and raised to 2.3-3 million due to the addition of molecular data (Hawksworth 2012, Hawksworth \& Lucking 2017). Studies on fungal diversity have increased with new molecular approaches and numerous fungal species, cryptic species and species complexes have been discovered (Petersen \& Hughes 2012, Ekanayaka et al. 2017, Hongsanan et al. 2017, Hyde et al. 2017, 2018, Tedersoo et al. 2018). Thus, previous fungal estimates have increased. In 2018, fungal species numbers were estimated between 2.2-3.8 million (Willis 2018). This majority of new fungal species were recorded from Asia, accounting for 35\%, followed by Europe (25\%), Oceania (14\%), South America (12\%), North America (9.5\%), and Africa (4\%). Novel taxa have usually been discovered in areas where most fungal taxonomists work with the rate of discovery of new species being more than 2,000 species per year, especially in Ascomycota and Basidiomycota (Blackwell 2011, Willis 2018). However, fungal diversity is immense with less than $10 \%$ of species extant and there is considerable work still to do (James \& Berbee 2012, Hawksworth \& Lucking 2017, Hyde et al. 2020a).

This paper is a continuation of Mycosphere Notes and introduces a new genus, 18 new species and one new host record. All taxa described herein are based on morphological characterization and phylogenetic analyses. This series complements other series such as Fungal Diversity Notes (Liu et al. 2015, Hyde et al. 2019b, 2020b, c) and Fungal Planet (Crous et al. 2006, 2018).

\section{Materials \& Methods}

\section{Collection and Isolation}

Fungal specimens were collected from China, the Republic of Korea, and Thailand. Specimens were incubated in a moist chamber for 3-7 days at $25^{\circ} \mathrm{C}$, to induce sporulation. Pure cultures were isolated by a modified single spore isolation method (Manamgoda et al. 2012, Chomnunti et al. 2014, Senanayake et al. 2020). Growth rate, colony characteristics and sexual/asexual morph morphology were determined from cultures grown on potato dextrose agar 
(PDA). Macro and Microscopic structures were observed with a stereo microscope (Motic SMZ168) and a Nikon ECLIPSE 80i compound microscope fitted with a Canon 750D digital camera. Measurements were made using Tarosoft (R) Image Frame Work. Photomicrographs were processed with Adobe Photoshop CS6 Extended version 10.0 (Adobe Systems, USA). Representative specimens are deposited in the herbarium of Mae Fah Luang University, Chiang Rai Province, Thailand (MFLU), Herbarium Mycologicum Academiae Sinicae (HMAS), Herbaria of Guizhou Academy of Agricultural Sciences (GZAAS), Jilin Agricultural University, Jilin Province, China (HMJAU), and Cryptogams Kunming Institute of Botany, Academia Sinica, Yunnan Province, China (HKAS). Representative cultures are deposited at Mae Fah Luang Culture Collection (MFLUCC), Jilin Agricultural University Culture Collection (JLAUCC) and Herbarium of Cryptogams, Kunming Institute of Botany, Academia Sinica (HKAS), Kunming Culture Collection (KUMCC). Faces of fungi numbers and Index Fungorum numbers were obtained as outlined in Jayasiri et al. (2015) and Index Fungorum (2021).

\section{DNA extraction, PCR amplification and sequencing}

DNA extraction followed the method of Thambugala et al. (2015). The PCR amplifications were performed in a total volume of $25 \mu \mathrm{L}$ of PCR mixture containing TaKaRa Ex-Taq DNA polymerase $0.3 \mu \mathrm{L}, 12.5 \mu \mathrm{L}$ of $2 \mathrm{X}$ PCR buffer, $2.5 \mu \mathrm{L}$ of dNTPs, $1 \mu \mathrm{L}$ of genomic DNA, $1 \mu \mathrm{L}$ of each primer and $12.2 \mu \mathrm{L}$ of deionized water. The internal transcribed spacer (ITS), small subunit ribosomal RNA (SSU), large subunit ribosomal RNA (LSU), RNA polymerase II second largest subunit ( $r p b 2)$, translation elongator factor alpha (tef-1) and beta-tubulin (tub2) gene regions were amplified using primer pairs ITS4/ITS5 (White et al. 1990), LR0R/LR5 (Vilgalys \& Hester 1990), NS1/NS4 (White et al. 1990), RPB2-5f2/RPB2-7cr (Liu et al. 1999, Sung et al. 2007), EF-1/EF-2 (O’Donnell et al. 1998) and T1/Bt2b (Glass \& Donaldson 1995, O’Donnell \& Cigelnik 1997), respectively. The conditions for amplification of each gene were followed an initial denaturation step of $5 \mathrm{~min}$ at $94^{\circ} \mathrm{C}$ followed by 35 cycles of $30 \mathrm{~s}$ at $94^{\circ} \mathrm{C}, 50 \mathrm{~s}$ at $52^{\circ} \mathrm{C}$ (ITS, LSU, SSU) or $55^{\circ} \mathrm{C}$ $(t e f-1, r p b 2, t u b 2)$ and $1 \mathrm{~min}$ at $72^{\circ} \mathrm{C}$, and a final extension step of $7 \mathrm{~min}$ at $72^{\circ} \mathrm{C}$. The PCR products were verified by staining with ethidium bromide after separation on $1 \%$ agarose electrophoresis gels and purified according to the manufacturer's instructions of a Qiangen purification kit (Qiagen, Hilden, Germany). DNA sequencing was done by Sunbiotech Company, Beijing, China. The DNA sequences generated in this study are deposited in GenBank.

\section{Sequence alignment and phylogenetic analysis}

Analysis of the sequences was conducted by submission to GenBank via BLAST tool (http://blast.ddbj.nig.ac.jp/top-e.html). The sequences from this study and reference sequences from previous studies were used in the phylogenetic analysis. Separate phylogenetic analyses were carried out to determine the placement of each fungal taxon based on selected combinations of ITS, LSU, SSU, rpb2, tef-1 and tub2 sequence data. SeqMan V.5.0 was used to obtain consensus sequences from sequences generated from forward and reverse primers. Sequences were aligned with Clustal X v.1.81 (Thompson et al. 1997) and were further aligned using default settings of MAFFT v.7 (Katoh \& Standley 2013, http://mafft.cbrc.jp/alignment/server/). Alignments were manually adjusted using BioEdit V.7.0.9.0 (Hall 2005) where necessary.

A phylogenetic tree was constructed for maximum likelihood (ML), maximum parsimony (MP), and Bayesian inference (BI) methods. The MP analysis was performed using PAUP v. $4.0 \mathrm{~b} 10$ (Swofford 2002) to obtain the most parsimonious trees. Gaps were treated as missing data and ambiguously aligned regions were excluded. Trees were inferred using the heuristic search option with Tree Bisection Reconnection (TBR) branch swapping and 1000 random sequence additions. Maxtrees were set up to 5,000 branches of zero length were collapsed and all multiple parsimonious trees were saved. Descriptive tree statistics for parsimony (tree length [TL], consistency index [CI], retention index [RI], rescaled consistency index [RC], and homoplasy index $[\mathrm{HI}])$ were calculated for trees generated under different optimality criteria. The robustness of the most parsimonious trees was evaluated by 1,000 bootstrap replications resulting from maximum 
parsimony analysis (Hillis \& Bull 1993). The ML analysis was carried out on RAxML v7.0.3 using the GTR+I+G model with 1000 bootstrap replications (Felsenstein 1985, Stamatakis 2014). The BI analysis was performed with MrBayes v3.2.6 (Ronquist et al. 2012). The best substitution models were estimated by Akaike Information Criterion (AIC) in jModeltest 2.1.10 (Darriba et al. 2012). For the BI analysis, six simultaneous Markov chains were run for 1000000 generations and trees were sampled every 100th generation. The 2000 trees representing the burn-in phase of the analyses were discarded and the remaining 8000 trees used for calculating posterior probabilities (PP) in the majority rule consensus tree. Trees were rooted with given outgroups in each analysis. MP/ML bootstrap supports (BS) (greater than or equal to 75\%) and PP (greater than or equal to 0.90) are shown below or above each branch. Phylograms were visualized with TreeView (Page 1996) and FigTree v1.4.0 program (Rambaut 2012) and reorganized in Microsoft power point (2010) and Adobe Illustrator CS5 (Version 15.0.0, Adobe, San Jose, CA).

\section{Results}

\section{Taxonomy}

325. Hypsostroma thailandicum J.Y Zhang, Y.Z. Lu \& K.D. Hyde, sp. nov.

Fig. 1

Index Fungorum number: IF558529, Faces of fungi number: FoF 09900

Etymology - 'thailandicum' reference to the location, Thailand, where the holotype was collected.

Holotype - MFLU 21-0086

Saprobic on decaying wood in terrestrial habitats. Sexual morph: Ascomata 340-460 $\mu \mathrm{m}$ high $\times 360-460 \mu \mathrm{m}$ diam, superficial, clustered, numerous, subglobose to globose, black. Setae / hyphal filaments 150-650 $\mu \mathrm{m}$ long, 4.5-7.5 $\mu \mathrm{m}$ wide, abundant, cylindrical, brown to dark brown, 3-10septate, straight or bent, apex rounded. Peridium 55-80 $\mu \mathrm{m}$ thick, composed of several layered cells of textura prismatica, with inner cells pale brown and outer cells dark brown. Pseudoparaphyses 1-2.5 $\mu \mathrm{m}$ wide, numerous, hyaline, septate, branched, filiform. Asci 180-440 $\times$ 8.5-14 $\mu \mathrm{m}(\overline{\mathrm{x}}=247 \times 11 \mu \mathrm{m}, \mathrm{n}=20)$, polysporous, unitunicate, elongate clavate, very long-stalked, thin walled, apically rounded. Ascospores 7-14.5 $\times 2.5-6 \mu \mathrm{m}(\overline{\mathrm{x}}=9.5 \times 4 \mu \mathrm{m}, \mathrm{n}=50)$, 2-seriate, olivaceous when young, brown to dark brown when mature, oblong, long triangular to cuneiform, with acute end cells, aseptate, straight to slightly curved, end cells slightly longer than central cells, guttulate. Asexual morph: Undetermined.

Culture characteristics - Ascospores germinated on PDA within 12 hours from single-spore isolation. Colonies diameter reaching 35-40 mm after 4 weeks at $26^{\circ} \mathrm{C}$ on PDA media. Mycelia superficial, irregular, filiform, umbonate, dark brown from above and below.

Material examined - Thailand, Chiang Rai Province, Mae Fah Luang University, on dead wood, 1 November 2019, N.G Liu, N1 (MFLU 21-0086, holotype), ex-type living culture, MFLUCC 21-0057. GenBank accession numbers (LSU) MZ435867 and (ITS) MZ435865.

Notes - Hypsostroma thailandicum shares the same morphology with other species of Hypsostroma in having clustered, superficial ascomata, abundant pseudoparaphyses, numerous elongate clavate, very long-stalked asci and oblong ascospores (Huhndorf 1992). Hypsostroma caimitalensis is the closest species based on a BLAST search of the LSU region with 94.7\% similarity. A multi-loci phylogenetic analyses showed that $H$. thailandicum is a distinct species and sister to the type species, $H$. caimitalensis with $89 \%$ MP, 1.00 PP support (Fig. 2). Our collection differs from $H$. caimitalensis in the absence of an ostiolar neck, abundant, long setae, smaller ascomata (340-460 $\mu \mathrm{m}$ high $\times 360-460 \mu \mathrm{m}$ diameter vs 650-900 $\mu \mathrm{m}$ diameter, $1500-1800 \mu \mathrm{m}$ high) and smaller ascospores $(7-14.5 \times 2.5-6 \mu \mathrm{m}$ vs 40-4 $7 \times 5.5-6.5 \mu \mathrm{m})$ (Huhndorf 1992). Therefore, we introduce $H$. thailandicum as a new species. Only two species are accepted in Hypsostroma; $H$. caimitalensis and $H$. saxicola, and both only have LSU sequence data. Therefore, sequence data and new collections are needed for this genus. 

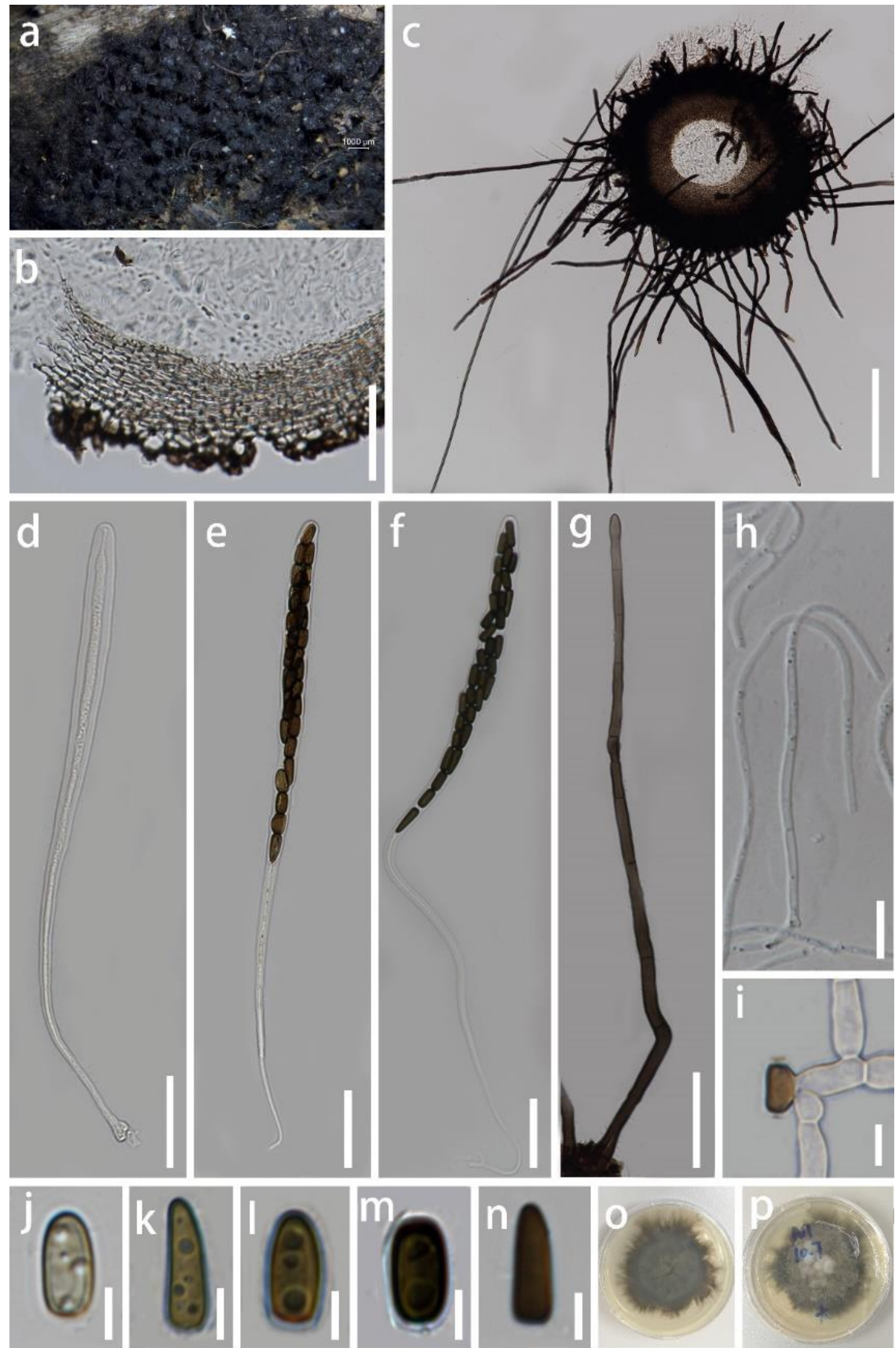

Figure 1 - Hypsostroma thailandicum (MFLU 21-0086, holotype). a Superficial ascomata on substrate, note ascomata surrounded by black setae. b Peridium. c Section of ascoma. $\mathrm{d}-\mathrm{f}$ Asci. g Seta. h Pseudoparaphyses. i Germinating ascospores. $\mathrm{j}-\mathrm{n}$ Ascospores. o, $\mathrm{p}$ Colonies on PDA. Scale bars: $b, g=50 \mu \mathrm{m}, \mathrm{c}=200 \mu \mathrm{m}, \mathrm{d}-\mathrm{f}=20 \mu \mathrm{m}, \mathrm{h}, \mathrm{i}=10 \mu \mathrm{m}, \mathrm{j}-\mathrm{n}=5 \mu \mathrm{m}$. 


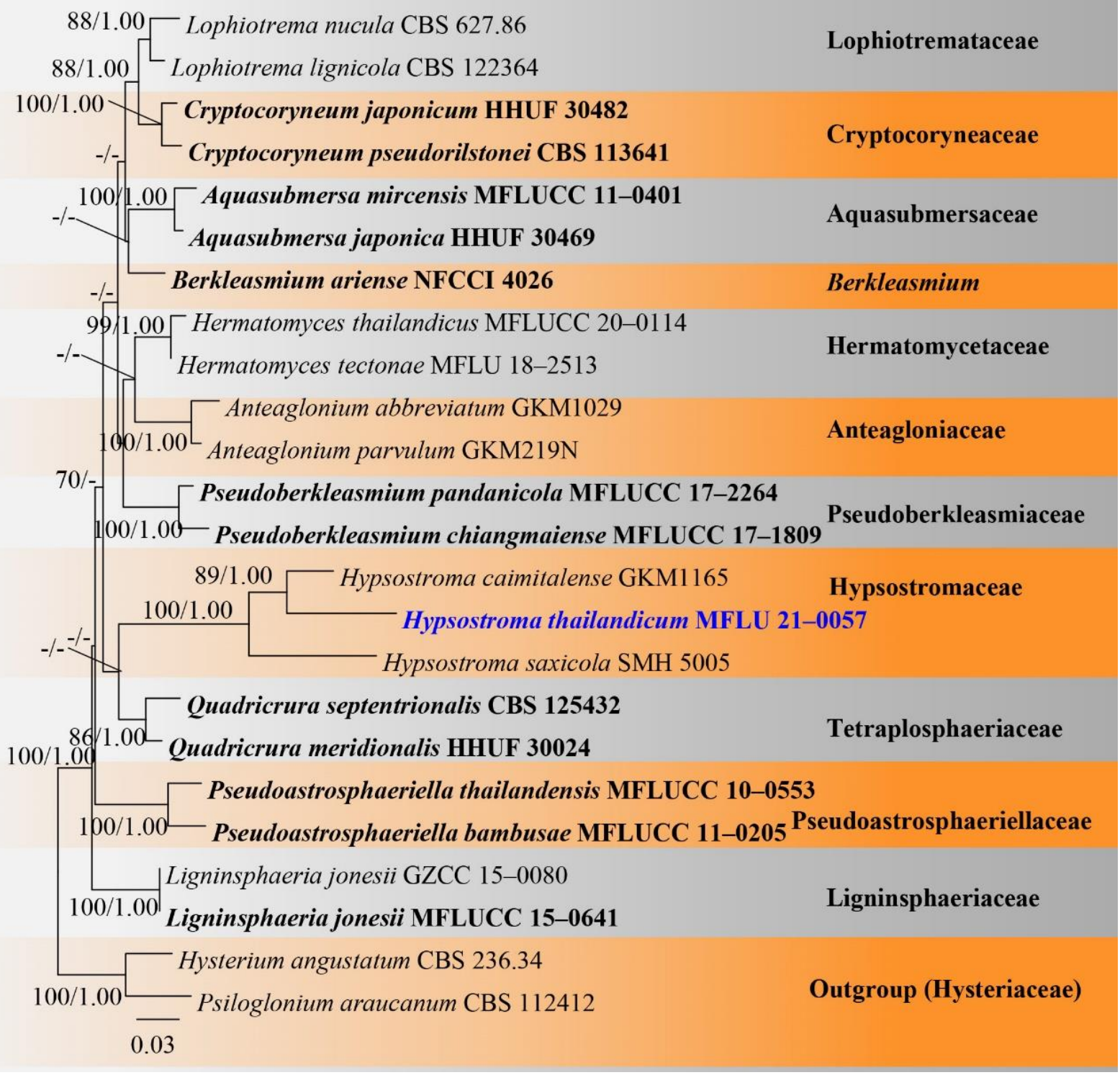

Figure 2 - Phylogenetic tree derived from maximum likelihood analysis of a combined LSU, ITS, SSU and tef- 1 genes of 24 sequences and the aligned dataset was comprised of 3231 characters including gaps (LSU: 1-816 bp, ITS: 817-1326 bp, SSU: 1327-2247 bp and tef-1: 2248-3231 bp). The average standard deviation of the split frequencies of the BI analysis was 0.007236 . A best scoring RAxML tree was established with a final ML optimization likelihood value of 11350.313661. The matrix had 716 distinct alignment patterns with $38.84 \%$ undetermined characters or gaps. Estimated base frequencies were found to be: $\mathrm{A}=0.239526, \mathrm{C}=0.249241, \mathrm{G}=$ $0.277904, \mathrm{~T}=0.233329$; substitution rates $\mathrm{AC}=1.425843, \mathrm{AG}=2.696690, \mathrm{AT}=1.253078, \mathrm{CG}=$ $0.822248, \mathrm{CT}=10.258257, \mathrm{GT}=1.000000$; proportion of invariable sites $=0.790467$ and gamma distribution $=0.152852$. Hysterium angustatum CBS 236.34 and Psiloglonium araucanum CBS 112412 were used as outgroup taxa. Numbers above branches are the bootstrap statistics percentages (left) and Bayesian posterior probabilities (right). Branches with bootstrap values $\geq 70 \%$ are shown at each branch and the bar represents 0.03 substitutions per nucleotide position. Hyphen (-) represents support values $\leq 70 \% / 0.95$. Ex-type strains are in black bold, newly generated sequence is indicated in blue and bold for new taxa.

326. Halobyssothecium thailandica D.F. Bao, Z.L. Luo, K.D. Hyde \& H.Y. Su, sp. nov. Fig. 3 Index Fungorum number: IF 558523; Facesoffungi number: FoF 09922 Etymology - 'thailandica' referring to the species was collected from Thailand. 

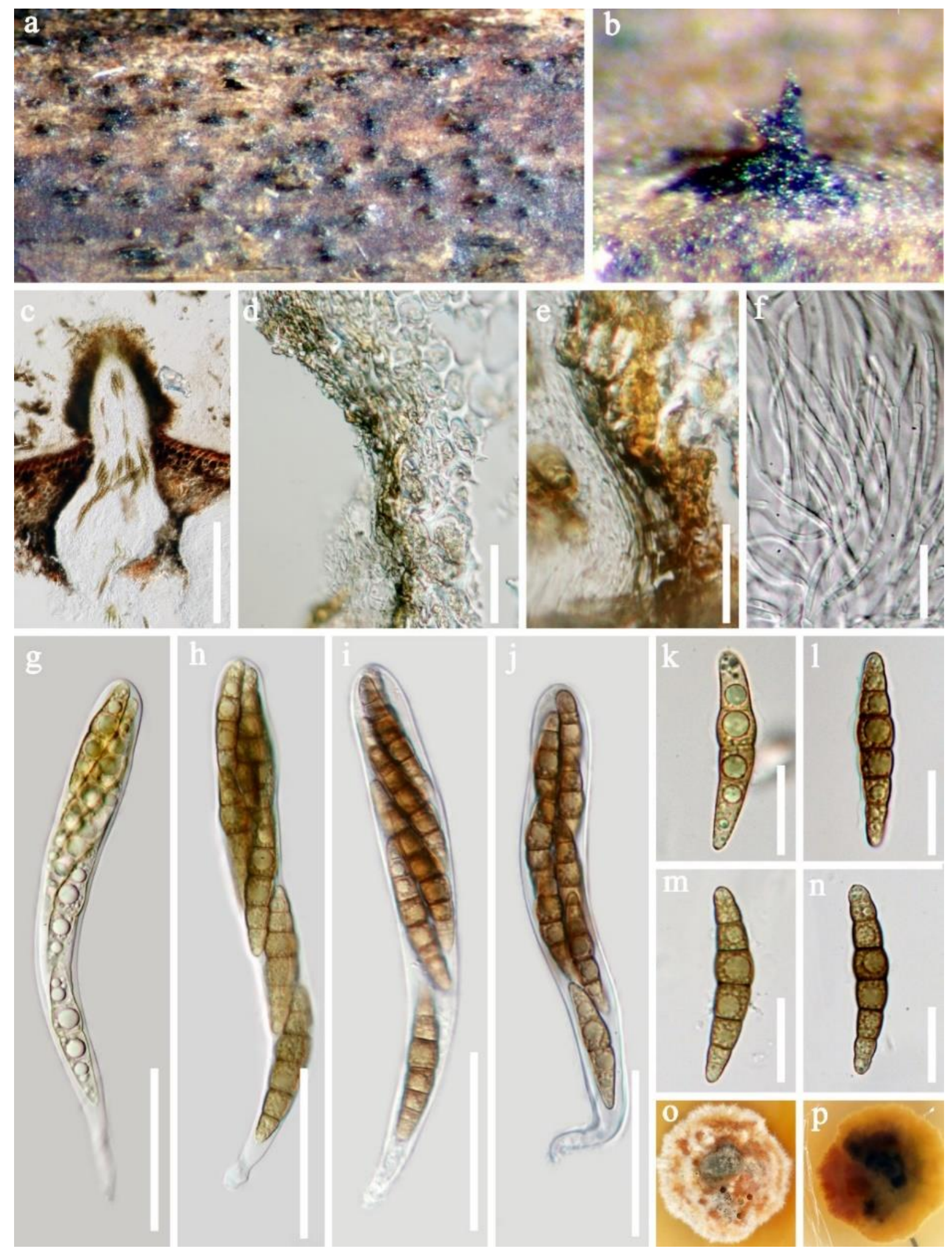

Figure 3 - Halobyssothecium thailandica (MFLU 21-0077, holotype). a, b Appearance of ascomata on the host. c Sections of ascomata. d, e Section of peridium. f Pseudoparaphyses. $\mathrm{g}-\mathrm{j}$ Asci. $\mathrm{k}-\mathrm{n}$ Ascospores. $\mathrm{o}, \mathrm{p}$ Colony on MEA. Scale bars: $\mathrm{c}=200 \mu \mathrm{m}, \mathrm{d}=30 \mu \mathrm{m}, \mathrm{e}-\mathrm{f}, \mathrm{k}-\mathrm{n}=20$ $\mu \mathrm{m}, \mathrm{g}-\mathrm{j}=50 \mu \mathrm{m}$.

Saprobic on submerged decaying wood. Sexual morph: Ascomata 340-490 × 215-345 $\mu \mathrm{m}(\overline{\mathrm{x}}$ $=415 \times 280 \mu \mathrm{m}, \mathrm{n}=10$ ), immersed to semi-immersed, gregarious, scattered, carbonaceous, dark 
brown to black, as dark spots on host surface, ostiolate. Ostioles central, papillate, light brown to dark brown, composed of several layers of pseudoparenchymatous cells. Peridium 16-25 $\mu \mathrm{m}$ wide, comprising two layers, outer layer of brown pseudoparenchyma; inner layers of hyaline to pale brown cells of textura prismatica. Hamathecium comprising 1.5-2.5 $\mu \mathrm{m}(\mathrm{n}=30)$ wide, numerous, branched, septate, hyaline, cellular pseudoparaphyses. Asci 138-160 × 17-21 $\mu \mathrm{m}(\overline{\mathrm{x}}=148 \times 18$ $\mu \mathrm{m}, \mathrm{n}=20), 8$-spored, bitunicate, fissitunicate, cylindric-clavate, rounded at apex, with a short pedicellate. Ascospores 39-47 $\times 8-10 \mu \mathrm{m}(\overline{\mathrm{x}}=43.3 \times 8.9 \mu \mathrm{m}, \mathrm{n}=30)$, overlapping 2-3-seriate, hyaline when young, light brown to dark brown when mature, cylindric to clavate with round ends, tapering towards the base, straight or slightly curved, 4-7-septate, mostly 7-septate, constricted at the septa, guttulate, smooth-walled, surrounded by a gelatinous sheath. Asexual morph: Undetermined.

Culture characteristics - Ascospores germinating on PDA within 24 hours. Colonies on MEA effuse, greyish white to yellowish-brown, dense, circular, raised, undulate; reverse dark brown, reaching 3-4 cm diameter within 30 days at room temperature under natural light.

Material examined - Thailand, That Phanom, Nakhon Phanom, on submerged decaying wood, 13 November 2018, D.F. Bao, B-143 (MFLU 21-0077 holotype), ex-type living culture, MFLUCC 21-0062. GenBank accession numbers (LSU) MZ433248, (SSU) MZ429435 and (ITS) MZ429434.

Notes - There are ten species accepted in Halobyssothecium, four species are known from the asexual morphs and the other six species are known as sexual morphs (Dong et al. 2020, Calabon et al. 2021a). In our phylogenetic analyses, our new collection of $H$. thailandica was placed within Halobyssothecium and is sister to the asexual species, $H$. kunmingense and $H$. bambusicola with 76 ML/0.95 PP bootstrap support (Fig. 4). Our new collection fits well with the generic concept of Halobyssothecium in having immersed to semi-immersed, carbonaceous ascomata and 8-spored, clavate to subcylindrical asci with short pedicels and brown, septate ascospores. However, $H$. thailandica can be easily distinguished from other Halobyssothecium species by its light brown to dark brown and 4-7-septate ascospores surrounded by a gelatinous sheath, while other Halobyssothecium species are less than 4-septate and lacking a gelatinous sheath (Table 1). Halobyssothecium thailandica resembles $H$. cangshanense, $H$. carbonneanum and $H$. voraginesporum in having cylindric-clavate and brown ascospores, however, $H$. thailandica differs in having larger asci and larger ascospores with a greater number of septa (Table 1). Halobyssothecium thailandica has similar ascospore sizes as $H$. estuariae, $H$. obiones and $H$. versicolor. However, $H$. thailandica can be distinguished by the colour and septation of the ascospores; $H$. thailandica has light brown to brown, 7-septate ascospores, while ascospores of $H$. estuariae, $H$. obiones and $H$. versicolor are 3-septate and central cells are pale brown to dark brown with hyaline end cells (Dayarathne et al. 2018, Devadatha et al. 2020, Calabon et al. 2021a). In addition, $H$. thailandica is the only species in the genus that has ascospores with a gelatinous sheath.

327. Neolentithecia C. Phukhams., K.D. Hyde \& Y. Li, gen. nov.

Fig. 5

Index Fungorum number: IF558399; Facesoffungi number: FoF 09841

Etymology - Named after Lentithecium, but phylogenetically distinct.

Holotype - HMJAU 58777

Saprobic on dried twigs. Sexual morph: Ascomata solitary, gregarious, scattered, immersed, as shiny, black, dots visible on the host surface, uniloculate, coriaceous, ostiolate. Ostioles central, black. Peridium thick, multilayered, of cells arranged in textura angularis, brown to dark brown, inner layer lined with sub-hyaline cells of textura angularis. Hamathecium composed of numerous, cellular pseudoparaphyses, with distinct septa, anastomosing at the apex. Asci 8-spored, bitunicate, clavate, with furcate pedicel, apically rounded, with well-developed ocular chamber. Ascospores biseriate, hyaline to yellowish-brown, oval or obovoid, ends rounded, dictyosporous, constricted at the septa, with or without a mucilaginous sheath. Asexual morph: Undetermined.

Type species - Neolentithecia changchunensis C. Phukhams., K.D. Hyde, W.X. Su \& Y. Li 


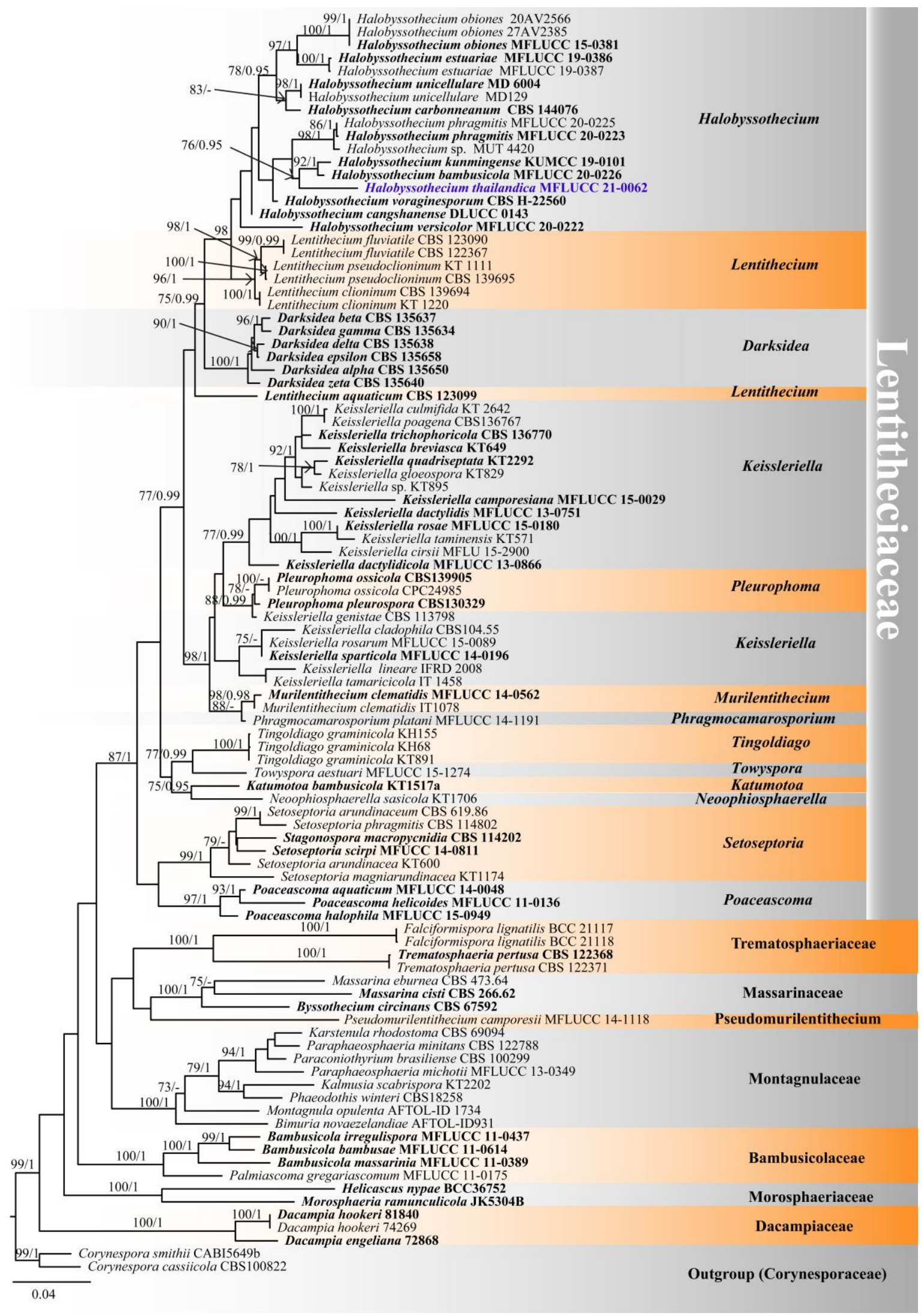

Figure 4 - Phylogenetic tree derived from maximum likelihood analysis of a combined LSU, SSU, ITS and tef- 1 genes of 97 sequences and the aligned dataset was comprised of 3480 characters including gaps (LSU: 1-882 bp, SSU: 883-1964 bp, ITS: 1965-2531 bp and tef-1: 2532-3480 bp). The average standard deviation of the split frequencies of the BI analysis was 0.009916. A best scoring RAxML tree was established with a final ML optimization likelihood value of -25052.917732. The matrix had 1487 distinct alignment patterns with $32.42 \%$ undetermined 
characters or gaps. Estimated base frequencies were found to be: $\mathrm{A}=0.238681, \mathrm{C}=0.247094, \mathrm{G}=$ 0.273953, $\mathrm{T}=0.240272$; substitution rates: $\mathrm{AC}=1.105011, \mathrm{AG}=2.303741, \mathrm{AT}=1.328566, \mathrm{CG}=$ 1.120074, $\mathrm{CT}=6.306370, \mathrm{GT}=1.000000$; gamma distribution $=0.191919$. Corynespora smithii (CABI 5649b) and C. cassiicola (CBS 100822) were used as outgroup taxa. Numbers above branches are the bootstrap statistics percentages (left) and Bayesian posterior probabilities (right). Branches with bootstrap values $\geq 75 \%$ are shown at each branch and the bar represents 0.1 substitutions per nucleotide position. Hyphen (-) represents support values < 75\%/0.95. Ex-type strains are in black bold, newly generated sequence is indicated in blue and bold for new taxa.

Notes - Muriform ascospores are polyphyletic throughout the Ascomycota (Hongsanan et al. 2020, Wijayawardene et al. 2020). The new genus Neolentithecia is typified by N. changchunensis, which is similar to Lentithecium in having globose, ostiolate ascomata with peridium cells of textura angularis, clavate asci and muriform ascospores (Wanasinghe et al. 2014). A multi-marker phylogenetic analysis of LSU, ITS, SSU and tef-1 show that Neolentithecia formed a clade with Lentithecium aquaticum (CBS 123099) (64\% ML/1.00 BPP, Fig. 6). Lentithecium is typified with L. fluviatile (Aptroot \& Van Ryck.) K.D. Hyde, J. Fourn. \& Ying Zhang, which formed a strong statistic support clade sister to Halobyssothecium and Darksidea (Fig. 6). However, L. aquaticum strain CBS 123099 does not cluster within Lentithecium sensu stricto (Calabon et al. 2021b), but formed an individual lineage. Thus, we assign another genus for the strain CCMJ10012 which clustered with L. aquaticum based on phylogenetic analysis, but is distinct from L. aquaticum by having well-developed ostioles and brown muriform ascospores (Zhang et al. 2009a, Tanaka et al. 2015). Lentithecium aquaticum (CBS 123099) was described from submerged wood in an aquatic habitat, while Neolentithecia has been found associated with woody substrate on terrestrial habitats (Zhang et al. 2009b). The two strains share similar climates in terms of weather and humidity (Jilin Province, China and France). This suggests that the strains may be limited by geographic barriers. We therefore, introduce a new genus based on morphological and phylogenetic evidence for a fungal collection on Sorbus species.

328. Neolentithecia changchunensis C. Phukhams., K.D. Hyde, W.X. Su \& Y. Li, sp. nov. Fig. 5 Index Fungorum number: IF558400; Facesoffungi number: FoF 09842

Etymology - 'changchunensis' named after the locality Changchun city, China.

Holotype - HMJAU 58777

Saprobic on dried twigs of Sorbus sp. Sexual morph: Ascomata 170-370 $\times 105-280 \mu \mathrm{m}(\overline{\mathrm{x}}=$ $260 \times 195 \mu \mathrm{m}, \mathrm{n}=5$ ), solitary, gregarious, scattered, immersed, black shiny dots visible on the host surface, uniloculate, globose, dark brown to black, coriaceous, papillate, ostiolate. Ostioles $86 \times 76$ $\mu \mathrm{m}$, central, black, semi-carbonaceous. Peridium 18-30 $\mu \mathrm{m}$ wide, composed of 9-12 layers of cells arranged in textura angularis, brown to dark brown, inner layer lined with sub-hyaline cells of textura angularis. Hamathecium composed of numerous, $1.6-3.5 \mu \mathrm{m}$ wide $(\overline{\mathrm{x}}=2.3 \mu \mathrm{m}, \mathrm{n}=25)$, filamentous, cellular pseudoparaphyses, with distinct septa, embedded in a mucilaginous matrix, anastomosing at the apex. Asci $105-152 \times 17-24 \mu \mathrm{m}(\overline{\mathrm{x}}=125 \times 20 \mu \mathrm{m}, \mathrm{n}=30)$, 8-spored, bitunicate, clavate, with furcate pedicel, apically rounded, with well-developed ocular chamber. Ascospores $19-26 \times 9-15 \mu \mathrm{m}(\overline{\mathrm{x}}=23 \times 12 \mu \mathrm{m}, \mathrm{n}=50)$, biseriate, partially overlapping, hyaline when young, yellowish-brown at maturity, oval or obovoid, ends rounded, with 3-6 longitudinal eusepta, one-transverse eusepta, with an oblique or longitudinal septum in the first cell from the apex, cell above median septum slightly enlarged, constricted at the septa, smooth-walled, without a mucilaginous sheath. Asexual morph: Undetermined.

Culture characteristics - Colonies on PDA reaching $20 \mathrm{~mm}$ diameter after 4 weeks at $25^{\circ} \mathrm{C}$. Culture from above dense, with aerial white and brown mycelium, umbonate at the centre, circular, cream at the margin, rough, with black mucous on the surface, lobate at the edge, cream at the margin, colony from below white at the centre, radiating cream outwardly.

Material examined - China, Jilin Province, Changchun District, Jilin Agricultural University, dried twigs of Sorbus sp. (Rosaceae), 12 March 2021, C. Phukhamsakda, CPJL01 (HMJAU 58777, 
holotype; HMJAU 58778, isotype), ex-type living culture, CCMJ10012). GenBank accession numbers (LSU) MZ518790, (SSU) MZ518820, (ITS) MZ519071, (tef-1) MZ514140 and (rpb2) MZ514139.

Notes - MegaBLAST searches of LSU, ITS and tef-1 sequences in GenBank of strain HMJAU 58777 showed the closest hit was Lentithecium aquaticum (CBS 123099). Neolentithecia changchunensis shows a close affinity to Lentithecium aquaticum (Fig. 6). Based on the distinct morphological traits and phylogeny, $N$. changchunensis is introduced as a new species. As $L$. aquaticum did not cluster within the clade of the type species of Lentithecium, thus fresh collections are required to verify the phylogenetic affiliation of L. aquaticum.

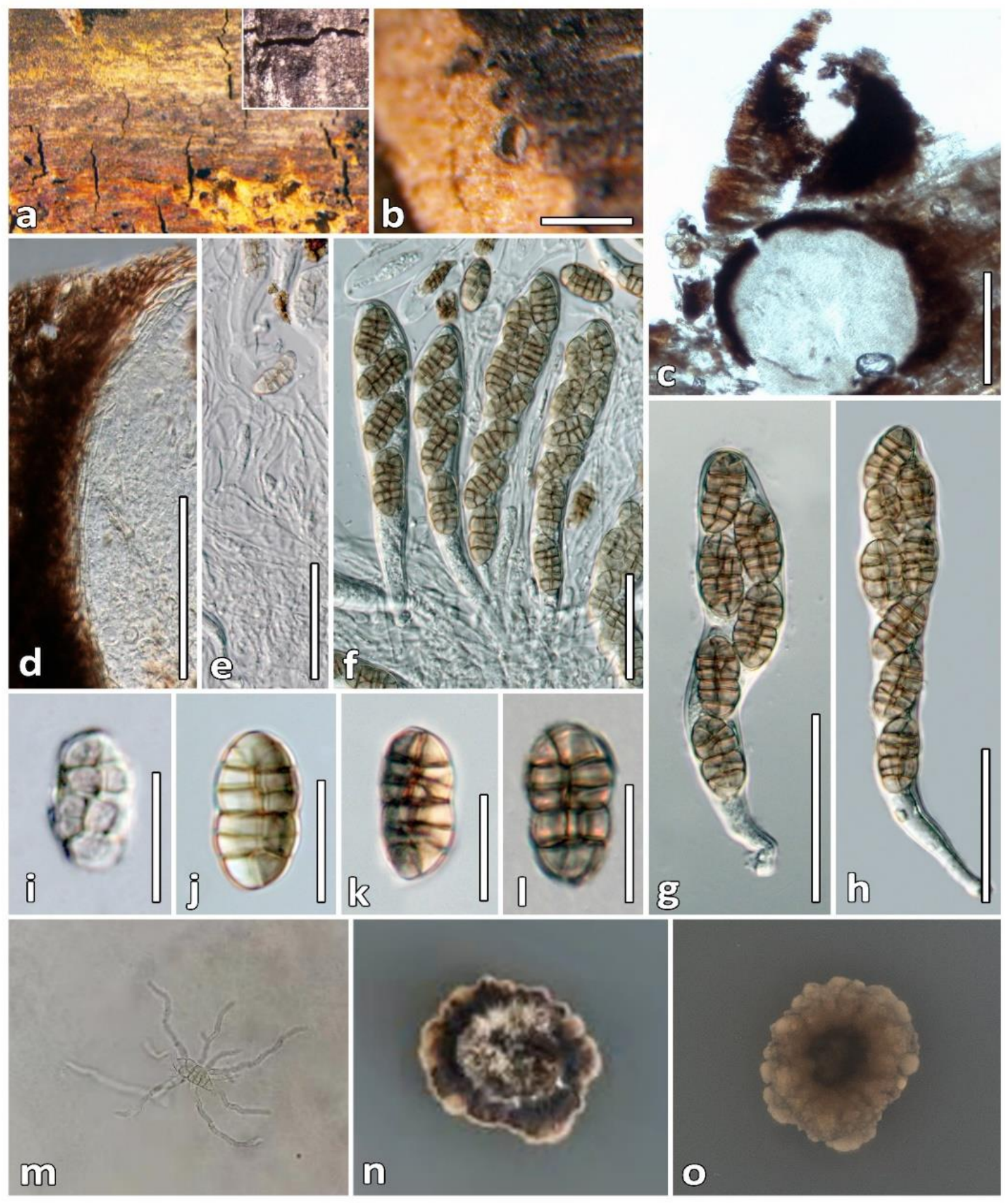

Figure 5 - Neolentithecia changchunensis (HMJAU 58777, holotype). a, b Ascomata scattered on the surface of Sorbus sp. c Section through ascoma. d Peridium. e Pseudoparaphyses. $\mathrm{f}-\mathrm{h}$ Asci. $\mathrm{i}-1$ Ascospores. $\mathrm{m}$ Germinated ascospores. $\mathrm{n}$, o Culture characters on PDA. Scale bars: $\mathrm{b}=500 \mu \mathrm{m}$, $\mathrm{c}=200 \mu \mathrm{m}, \mathrm{d}-\mathrm{h}=50 \mu \mathrm{m}, \mathrm{i}-\mathrm{-}=20 \mu \mathrm{m}$. 


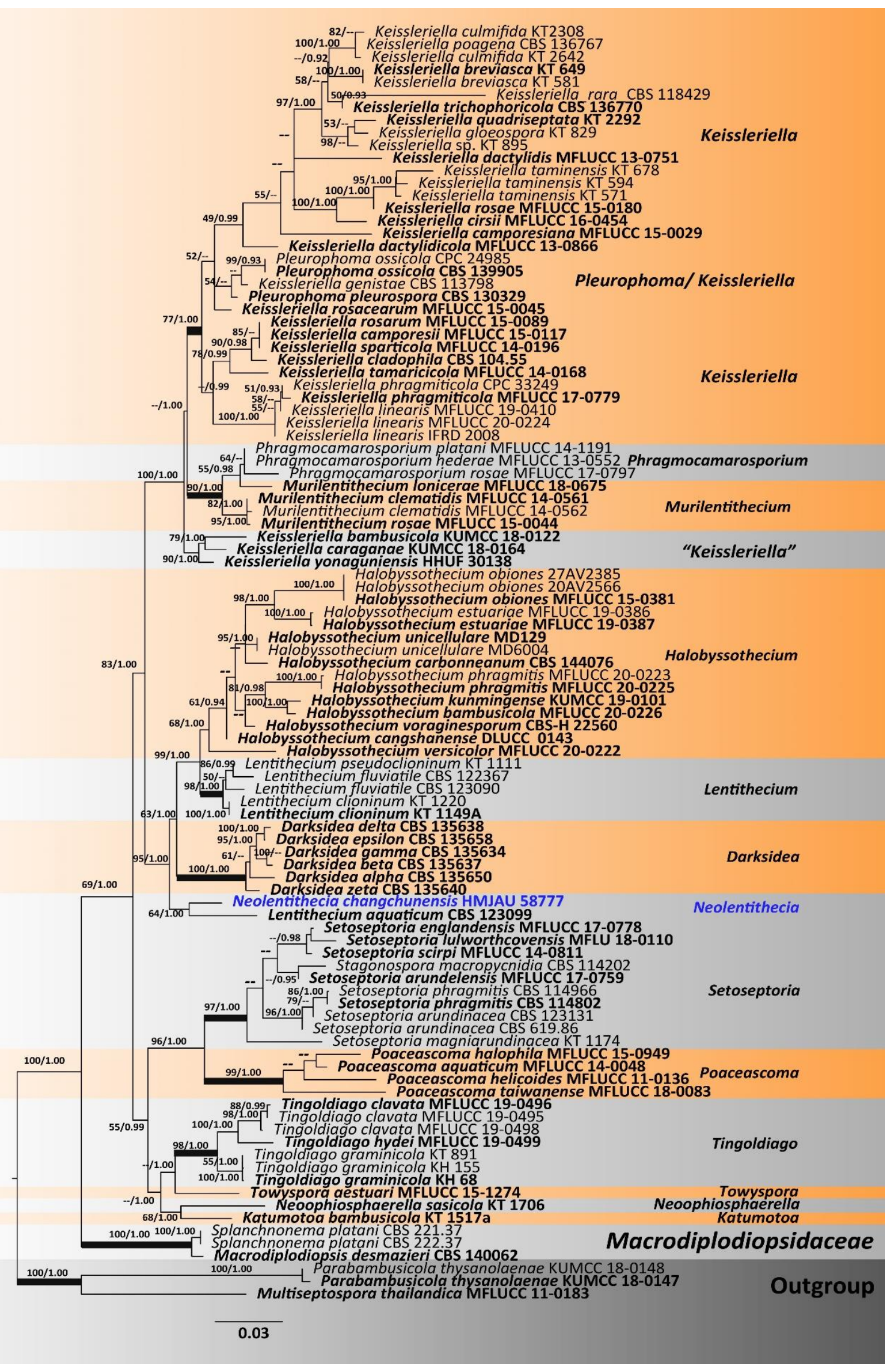

Figure 6 - Phylogram generated from maximum likelihood analysis based on combined LSU, SSU, ITS and tef- 1 sequence data representing the placement of Lentitheciaceae taxa. One hundred and one taxa were included in the combined analyses for the suitable taxonomic placement, which comprised 4525 characters (LSU: 921, SSU: 1404, ITS: 705, tef-1: 1495) after alignment. The best 
scoring RAxML tree with a final likelihood value of -38172.280131 is presented. The matrix had 2134 distinct alignment patterns, with $42.35 \%$ undetermined characters or gaps. Estimated base frequencies were as follows: $\mathrm{A}=0.236905, \mathrm{C}=0.249782, \mathrm{G}=0.273852, \mathrm{~T}=0.239461$; substitution rates: $\mathrm{AC}=1.066864, \mathrm{AG}=2.338368, \mathrm{AT}=1.332607, \mathrm{CG}=1.129133, \mathrm{CT}=$ 5.641144, GT $=1.000000$; gamma distribution shape parameter $\alpha=0.218687$. Bootstrap support values for ML equal to or greater than $60 \%$ and BPP equal to or greater than 0.95 are given above the nodes. Multiseptospora thailandica (MFLUCC 11-0183) and Parabambusicola thysanolaenae (KUMCC 18-0148; KUMCC 18-0147) were used as outgroup taxa. The newly generated sequence is indicated in blue. The ex-type strains are indicated in bold. Thick branches represent significant support values of greater than $75 \% \mathrm{ML}$ and BPP equal to or greater than 0.95 .

329. Pseudocapulatispora fragrantis C.F. Liao \& Doilom, sp. nov.

Fig. 7

Index Fungorum number: IF558530, Facesoffungi number: FoF 09897

Etymology - 'fragrantis' referring to the host name Heteropanax fragrans (Roxb.) Seem.

Holotype - KUMCC 21-0012

Saprobic on dead stem of Heteropanox fragrans. Sexual morph: Ascomata 220-377 $\times 162$ $325 \mu \mathrm{m}(\overline{\mathrm{x}}=303 \times 268 \mu \mathrm{m}, \mathrm{n}=30)$, immersed to erumpent, appearing as black spots or short black bands, coriaceous, solitary to scattered, globose to subglobose, base flattened, pyriform, light brown to black. Ostioles $74-195 \times 17-66 \mu \mathrm{m}(\overline{\mathrm{x}}=125 \times 32 \mu \mathrm{m}, \mathrm{n}=30)$, black short bands, crestlike, elongate and laterally compressed, carbonaceous, filled with hyaline periphyses. Peridium $7-$ $16 \mu \mathrm{m}$ wide $(\overline{\mathrm{x}}=12 \mu \mathrm{m}, \mathrm{n}=30)$, composed of 3-5 layers, brown to hyaline cells of textura angularis, based thin towards to the thickened ostiole. Hamathecium comprising 1.2-2.8 $\mu \mathrm{m}$ wide $(\overline{\mathrm{x}}=1.8 \mu \mathrm{m}, \mathrm{n}=30)$, dense, filiform, septate, branching pseudoparaphyses, short cylindrical to ovoid at the base. Asci 58-127 × 8-15 $\mu \mathrm{m}(\overline{\mathrm{x}}=99 \times 12 \mu \mathrm{m}, \mathrm{n}=30), 8$-spored, bitunicate, fissitunicate, cylindric-clavate, straight to slightly curved, apically rounded, with short, with furcate pedicel and ocular chamber. Ascospores $29-36 \times 4-8 \mu \mathrm{m}(\overline{\mathrm{x}}=32 \times 5 \mu \mathrm{m}, \mathrm{n}=30)$, overlapping biseriate, hyaline, aseptate when young, becoming one-septate when mature, constricted at the septa, broad fusiform, tapering towards the ends, straight to slightly curved, with 1-4 guttules when young, becoming two large guttules when mature, smooth-walled, with a broad sheath; sheath drawn out from apices of ascospores with polar appendages, $16-46 \times 8-14 \mu \mathrm{m}(\overline{\mathrm{x}}=26 \times 10 \mu \mathrm{m}, \mathrm{n}=$ 30 ), with globose drops at their apices. Asexual morph: Undetermined.

Culture characters - Ascospores germinating on PDA within 24h, germ tube produced from both ends. Colonies on PDA reaching 12-15 diam, after 2 weeks at room temperature $\left(25 \pm 2{ }^{\circ} \mathrm{C}\right)$, medium dense, raised at the center, circular, floccose to fluffy, velvety, brownish-greyish in the middle, whitish towards the margin; reverse brown to yellowish-brown, no pigment produced.

Material examined - China, Yunnan Province, Kunming, on dead stem of Heteropanox fragrans, 17 August 2019, C.F. Liao (KUN-HKAS 107635, holotype); ex-type culture KUMCC 21-0012. GenBank accession number (SSU) MZ475353, (LSU) MZ475352, (ITS) MZ475354 and (tef-1) MZ463059.

Notes - Pseudocapulatispora fragrantis (KUMCC 21-0012) clustered with P. longiappendiculata (MFLUCC 17-1452, ex-type, MFLUCC 17-1457), and P. clematidis (MFLUCC 17-2063, ex-type), but in separate branches with 100\% ML and 1.00 PP bootstrap support (Fig. 8). Pseudocapulatispora fragrantis differs from the holotype of $P$. longiappendiculata in having larger ascomata $(303 \times 268$ vs $240 \times 135 \mu \mathrm{m})$, thinner peridium $(7-16 \mathrm{vs} 15-25 \mu \mathrm{m})$, larger ascospores $(32 \times 5$ vs $26 \times 7.5 \mu \mathrm{m})$, with wider polar appendages $(26 \times 10$ vs $25 \times 4.5 \mu \mathrm{m})$. While, it differs from the holotype of $P$. clematidis in having longer ostiole $(125 \times 32$ vs $107 \times 66$ $\mu \mathrm{m})$, larger ascospores $(32 \times 5 \mathrm{vs} 25 \times 9 \mu \mathrm{m})$ and longer polar appendages $(26 \times 10 \mathrm{vs} 19 \times 4 \mu \mathrm{m})$. Thus, we introduce Pseudocapulatispora fragrantis as a new species based on morphology and phylogenetic evidence. 


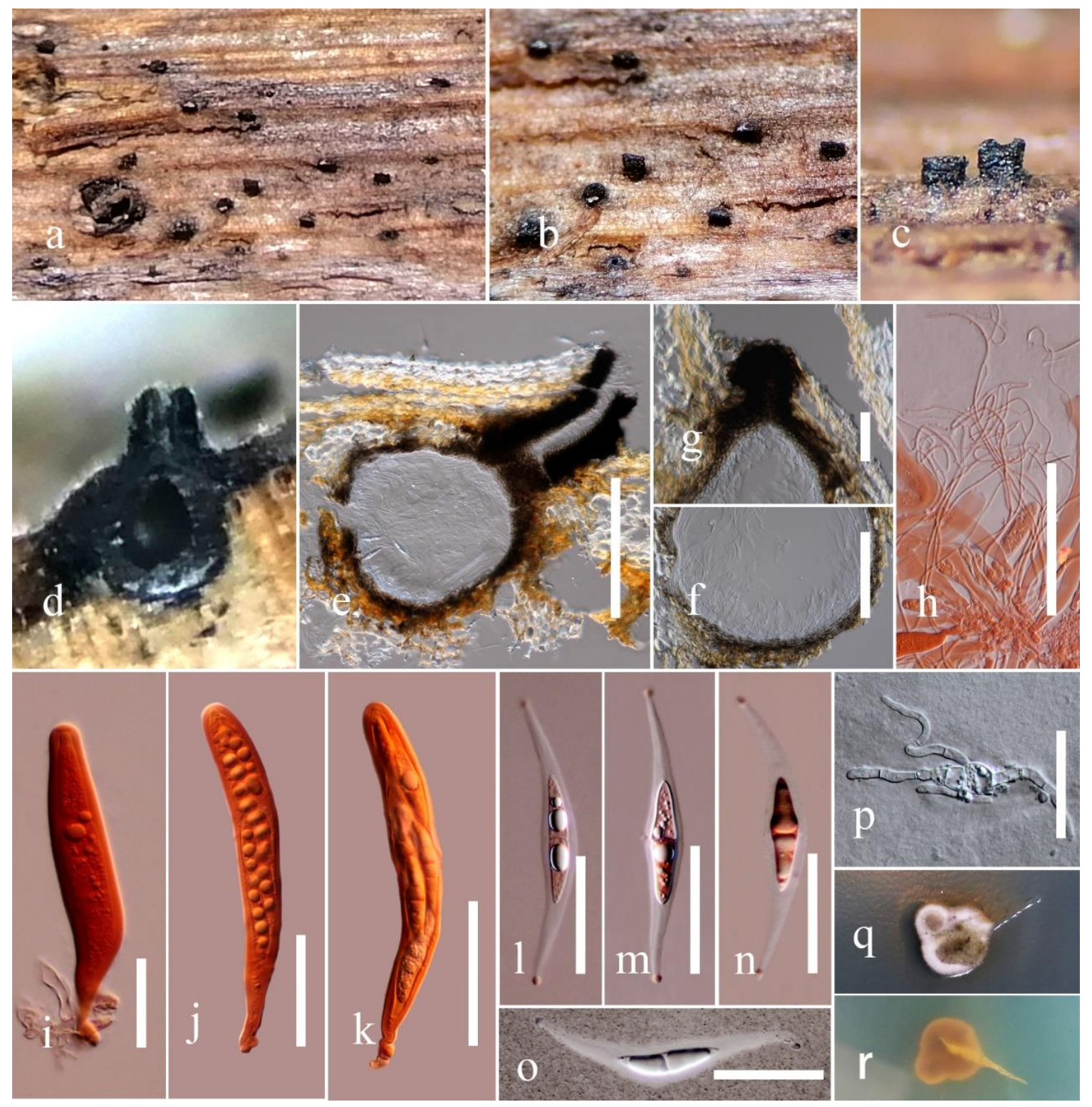

Figure 7 - Pseudocapulatispora fragrantis (KUN-HKAS 107635, holotype). a-c Appearance of ascomata on substrate. d, e Section through ascoma. f Peridium. g Ostiole. h Pseudoparaphyses stained in Congo red. i-k Asci stained in Congo red. $1-n$ Ascospores stained in Congo red. o Ascospore in Indian Ink. p Germinated ascospore. q, r Culture characteristics on PDA. Scale bars: $\mathrm{e}=500 \mu \mathrm{m}, \mathrm{f}, \mathrm{h}=200 \mu \mathrm{m}, \mathrm{g}, \mathrm{i}-\mathrm{o}=50 \mu \mathrm{m}, \mathrm{k}=20 \mu \mathrm{m}$.

330. Herpotrichia xiaokongense G.C. Ren \& K.D. Hyde, sp. nov.

Fig. 9

Index Fungorum number: IF558482; Facesoffungi number: FoF 09902

Etymology - 'xiaokongense' reference to the location, Xiaokong Mountain, where the holotype was collected.

Holotype - HKAS 112726

Saprobic on dead wood of Prunus sp. Sexual morph: Ascomata 340-500 $\mu \mathrm{m}$ high, 270-480 $\mu \mathrm{m}$ diameter $(\overline{\mathrm{x}}=390 \times 330 \mu \mathrm{m}, \mathrm{n}=5)$, immersed or superficial, black, coriaceous, globose to oval, with brown, septate tomentum, rounded apex broadly cap-like, opening by broad pore. Peridium $29-44 \mu \mathrm{m}(\overline{\mathrm{x}}=37.7 \mu \mathrm{m}, \mathrm{n}=10)$ thick at the base and both sides, $15-24 \mu \mathrm{m}(\overline{\mathrm{x}}=17.5 \mu \mathrm{m}$, $\mathrm{n}=10$ ) thick at apex light brown to brown, composed of 2-5 layers of thick-walled cells of textura angularis. Hamathecium comprising 2.5-3.5 $\mu \mathrm{m}$ wide, sparse, septate, branched pseudoparaphyses, embedded in a gelatinous matrix. Asci $100-155 \times 12-17 \mu \mathrm{m}(\overline{\mathrm{x}}=133.5 \times 14.3 \mu \mathrm{m}, \mathrm{n}=15)$, 8spored, bitunicate, fissitunicate, clavate to cylindrical, pedicellate rounded with an ocular chamber. 
Ascospores $31-41 \times 4.5-7 \mu \mathrm{m}(\overline{\mathrm{x}}=38.1 \times 5.5 \mu \mathrm{m}, \mathrm{n}=30)$, uni-seriate or overlapping bi-seriate, hyaline, fusoid with narrowly rounded ends, 1-septate, straight to slightly curved, constricted at the septum, with large guttules, surrounded by an expanded gelatinous sheath. Asexual morph: Undetermined.

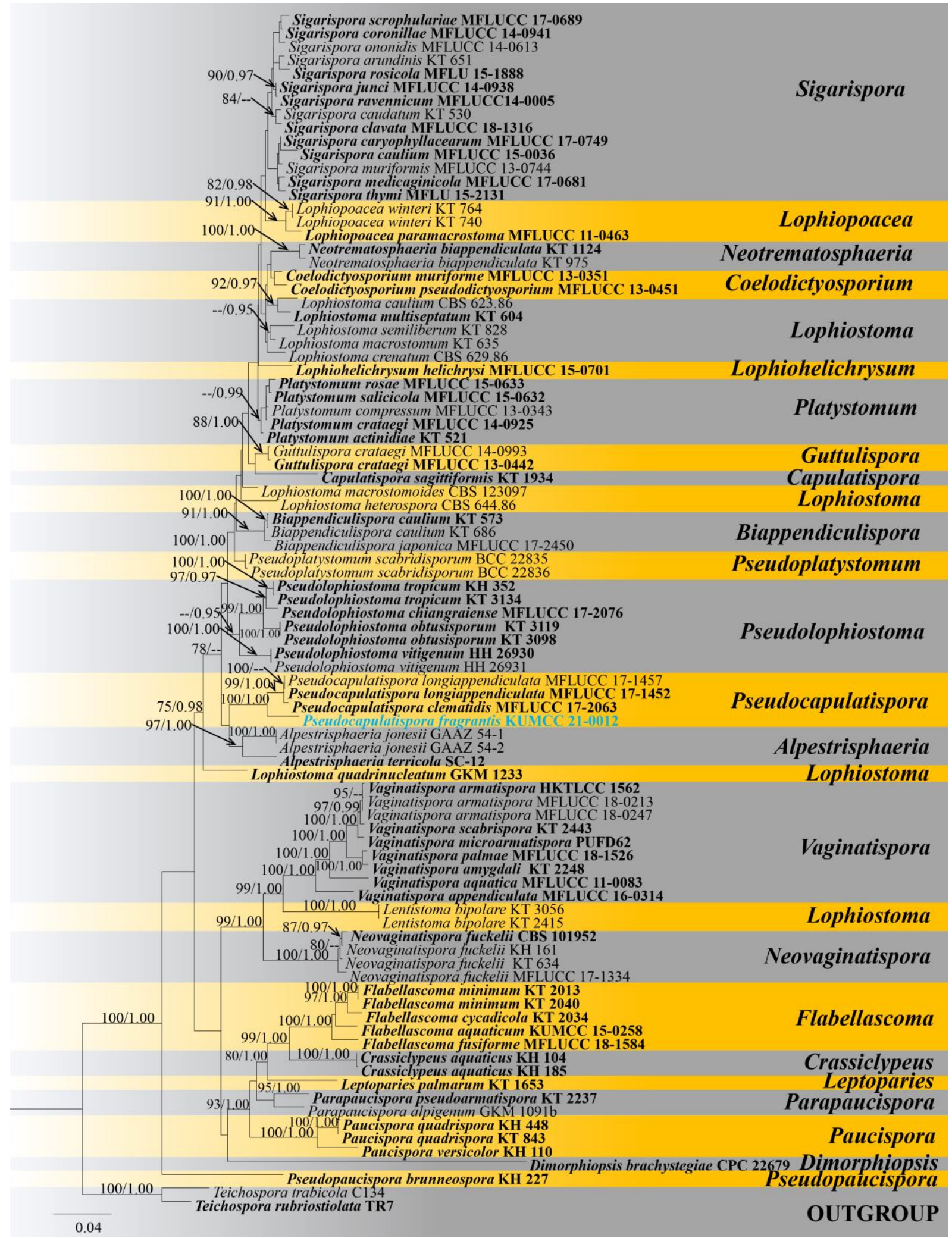

Figure 8 - Phylogram generated from maximum likelihood analysis based on combined SSU, ITS, LSU, tef-1 sequence data of Pseudocapulatispora. Bootstrap support values for ML equal to or greater than $75 \%$ and PP equal to or greater than 0.95 are given above the nodes. The ex-types and 
reference strains are in bold; the new isolate is in blue. The tree is rooted with Teichospora rubriostiolata (TR7) and T. trabicola (C134).
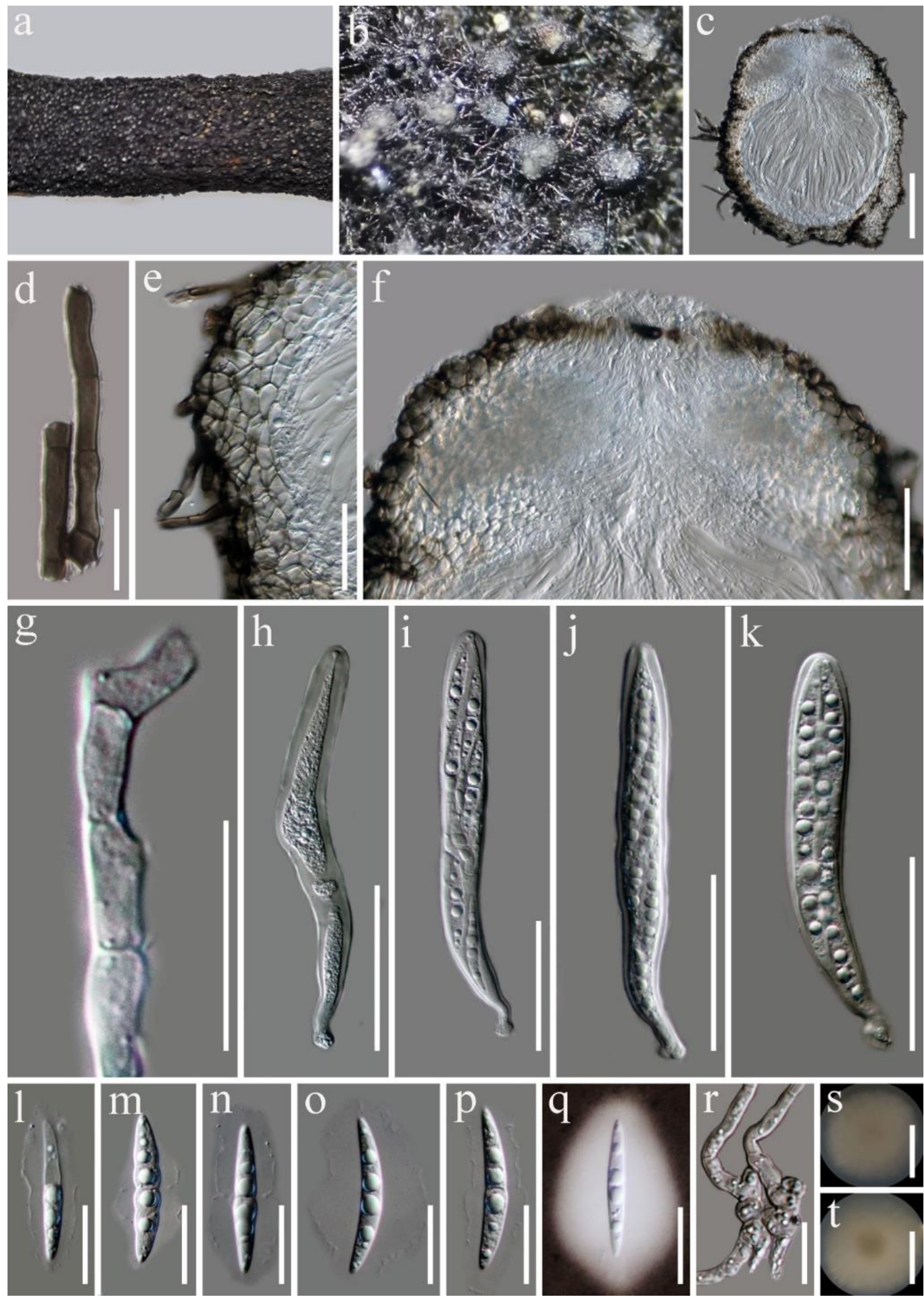

Figure 9 - Herpotrichia xiaokongense (HKAS 112726, holotype). a, b Appearance of ascomata on the host surface. c Vertical section through ascoma. $d$ Tomentum. e, $\mathrm{f}$ Peridium. g Pseudoparaphyses. h-k Asci. 1-p Ascospores with visible mucilaginous sheath. q Ascospore stained in Indian ink to show the mucilaginous sheath. $\mathrm{r}$ Germinated ascospore. $\mathrm{s}$, $\mathrm{t}$ Culture 
characters on PDA after one week ( $\mathrm{s}=$ from above, $\mathrm{t}=$ from below). Scale bars: $\mathrm{c}=100 \mu \mathrm{m}$, $\mathrm{d}=20 \mu \mathrm{m}, \mathrm{e}=40 \mu \mathrm{m}, \mathrm{f}=50 \mu \mathrm{m}, \mathrm{g}=15 \mu \mathrm{m}, \mathrm{h}-\mathrm{k}=50 \mu \mathrm{m}, \mathrm{l}-\mathrm{r}=20 \mu \mathrm{m}, \mathrm{s}, \mathrm{t}=15 \mathrm{~mm}$.

Material examined - China, Yunnan Province, Kunming City, Xiaokong Mountain $\left(25.171311^{\circ} \mathrm{N}, 102.703690^{\circ} \mathrm{E}\right)$, on dead wood of Prunus sp. (Rosaceae), 22 August 2020, GuangCong Ren, KM13 (HKAS 112726, holotype), ex-type living culture KUMCC 21-0004. GenBank accession numbers (SSU) MZ408890, (LSU) MZ408889 and (tef-1) MZ394066.

Culture characteristics - Colonies on PDA, reaching 20-30 mm diam, after one week at 20$25^{\circ} \mathrm{C}$, circular, white, crenate margins, fluffy, reverse white.

Notes - Herpotrichia xiaokongense is introduced as a new species based on morphological characters and phylogenetic analyses. Herpotrichia xiaokongense is distinct from extant species in Melanommataceae and formed a sister clade to $H$. macrotricha with 100\% ML, 1.00 PP bootstrap support (Fig. 10). Herpotrichia xiaokongense is similar to H. macrotricha in having broad cap-like ascomatal apex with a thick inner layer of hyaline pseudoparenchymatous cells (Mugambi \& Huhndorf 2009). However, Herpotrichia xiaokongense differs from H. macrotricha in having 1septate, hyaline ascospores with an expanded gelatinous sheath, while H. macrotricha has 1-(3-5)septate, hyaline to brown ascospores with narrow sheath often elongate over tips (Barr 1984, Chen \& Hsieh 2004, Tanaka \& Hosoya 2006).

331. Phragmocephala garethjonesii H.Y. Su, Udayanga \& K.D. Hyde, Phytotaxa 226: 201-216 (2015)

Fig. 11

Index Fungorum number: IF551025; Facesoffungi number: FOF 00574

Saprobic on dead wood of Rosa sp. Sexual morph: Undetermined. Asexual morph: Colonies superficial, scattered, glistening, dark brown to black. Conidiophores $90-135 \times 4.5-7 \mu \mathrm{m}(\overline{\mathrm{x}}=$ $105.2 \times 6 \mu \mathrm{m}, \mathrm{n}=10$ ), mononematous, macronematous, 4-7-septate, unbranched, erect, dark brown at the base, pale brown at the apex. Conidiogenous cells monoblastic, terminal, integrated, elongated, pale brown. Conidia 25-37 $\times 16-21 \mu \mathrm{m}(\overline{\mathrm{x}}=32.2 \times 18.1 \mu \mathrm{m}, \mathrm{n}=30)$, ellipsoidal, 4-6septate, pale brown at the apex and base, dark brown at middle cells, rounded at apex, truncate at base, often released with part of conidiogenous cell.

Culture characteristics - Colonies on PDA, reaching 25-30 mm diam, after one week at 20 $25^{\circ} \mathrm{C}$, circular, umbonate at the center, rough, zonate, granular on the surface, grey-white at the margin, grey between margin and center, white at the center, reverse white at the margin, atrovirens at the center.

Material examined - China, Yunnan Province, Diqing Autonomous Prefecture, Xianggelila $\left(27.28^{\prime} 8^{\circ} \mathrm{N}, 99.50^{\prime} 45^{\circ} \mathrm{E}\right)$, on dead wood of Rosa sp. (Rosaceae), 7 October 2020. Guang-Cong Ren, W03 (HKAS 112729), living culture KUMCC 20-0166. GenBank accession numbers (SSU) MZ408892, (LSU) MZ408890, (tef-1) MZ394067, (rpb2) MZ394068

Notes - Phragmocephala garethjonesii was introduced by $\mathrm{Su}$ et al. (2015) based on both morphology and phylogenetic analyses from decaying wood submerged in a stream in China. Based on our phylogenetic analysis of combined SSU, LSU, tef- 1 and rpb2 sequence data, our collection (KUMCC 20-0166) clusters with the type species of $P$. garethjonesii (MFLUCC 150018) with $100 \%$ ML, 1.00 PP bootstrap support. Our collection shares similar morphological features with P. garethjonesii (MFLUCC 15-0018). Based on morphological characteristics and phylogenetic analysis, we introduce KUMCC 20-0166 as new host record of $P$. garethjonesii from terricolous decaying wood of Rosa sp. (Rosaceae) in China.

332. Tarzetta confusa F.M. Yu, S. Wang, Q. Zhao \& K.D. Hyde, sp. nov.

Fig. 12

Index Fungorum number: IF558484; Facesoffungi number: FoF 09910

Etymology - In reference to it being easy to confuse this species with others in the genus.

Holotype - HKAS 115755 


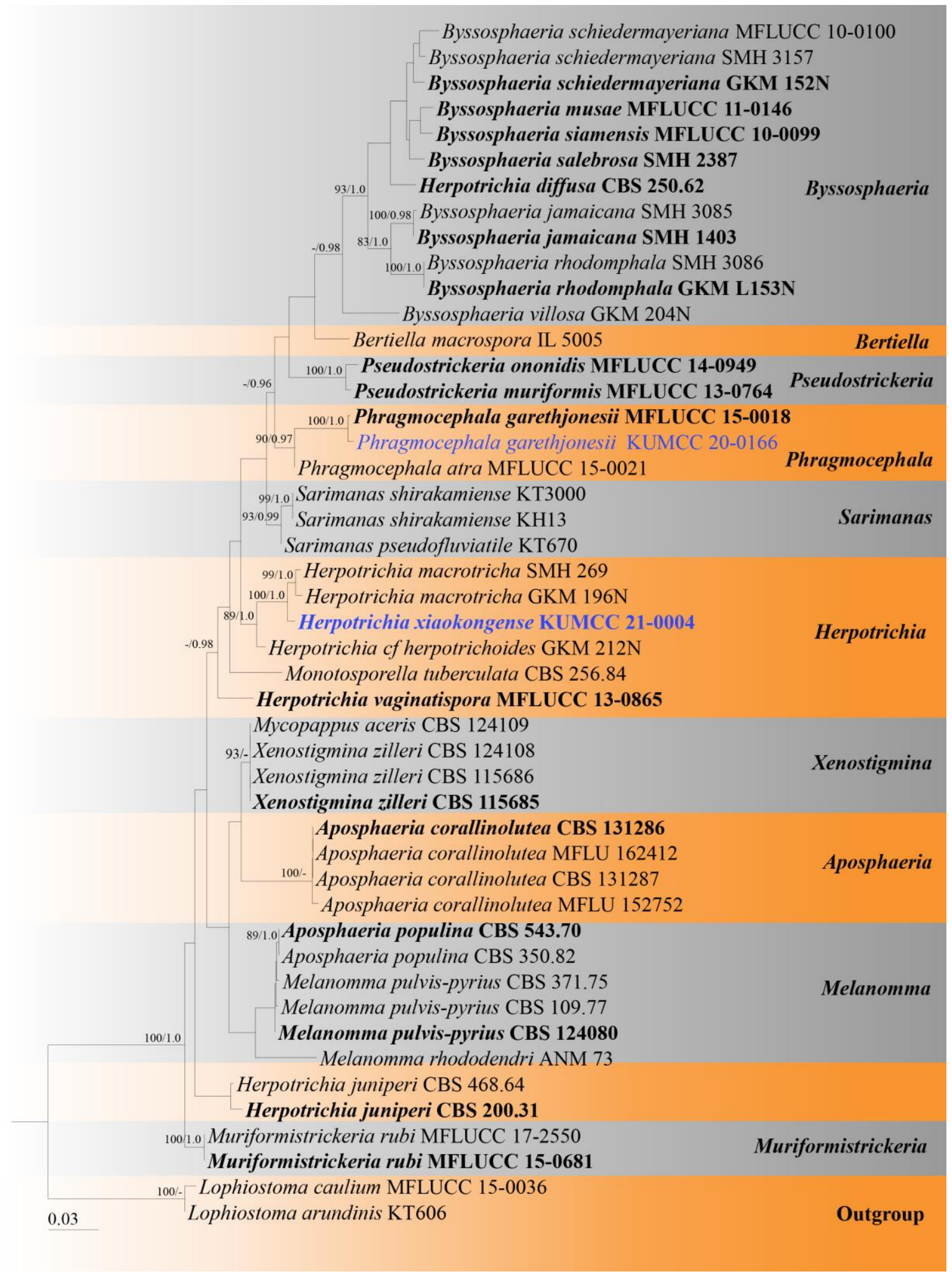

Figure 10 - Phylogram generated from maximum likelihood analysis based on combined SSU, LSU, tef- 1 and $r p b 2$ sequence data representing the species of Melanommataceae. Related sequences are taken from Tian et al. (2015). Forty-seven taxa were included in the combined analyses, which comprised 3823 characters (SSU = 999 bp, LSU = 916 bp, tef- $1=930, r p b 2=978$ ) after alignment. The best scoring RAxML tree with a final likelihood value of -12634.194587 is presented. Estimated base frequencies were as follows: $\mathrm{A}=0.251628, \mathrm{C}=0.233895, \mathrm{G}=0.278686$, $\mathrm{T}=0.235791$; substitution rates: $\mathrm{AC}=1.241005, \mathrm{AG}=4.382414, \mathrm{AT}=1.189360, \mathrm{CG}=1.014729$, $\mathrm{CT}=11.424207, \mathrm{GT}=1.000000$; gamma distribution shape parameter $\alpha=0.111393$. Bootstrap support values for ML equal to or greater than $75 \%$ and PP equal to or greater than 0.95 are given 
above the nodes. Lophiostoma arundinis (KT606) and L. caulium (MFLUCC 15-0036) are used as outgroup taxa. The newly generated sequence is indicated in blue. The ex-type strains are indicated in bold.
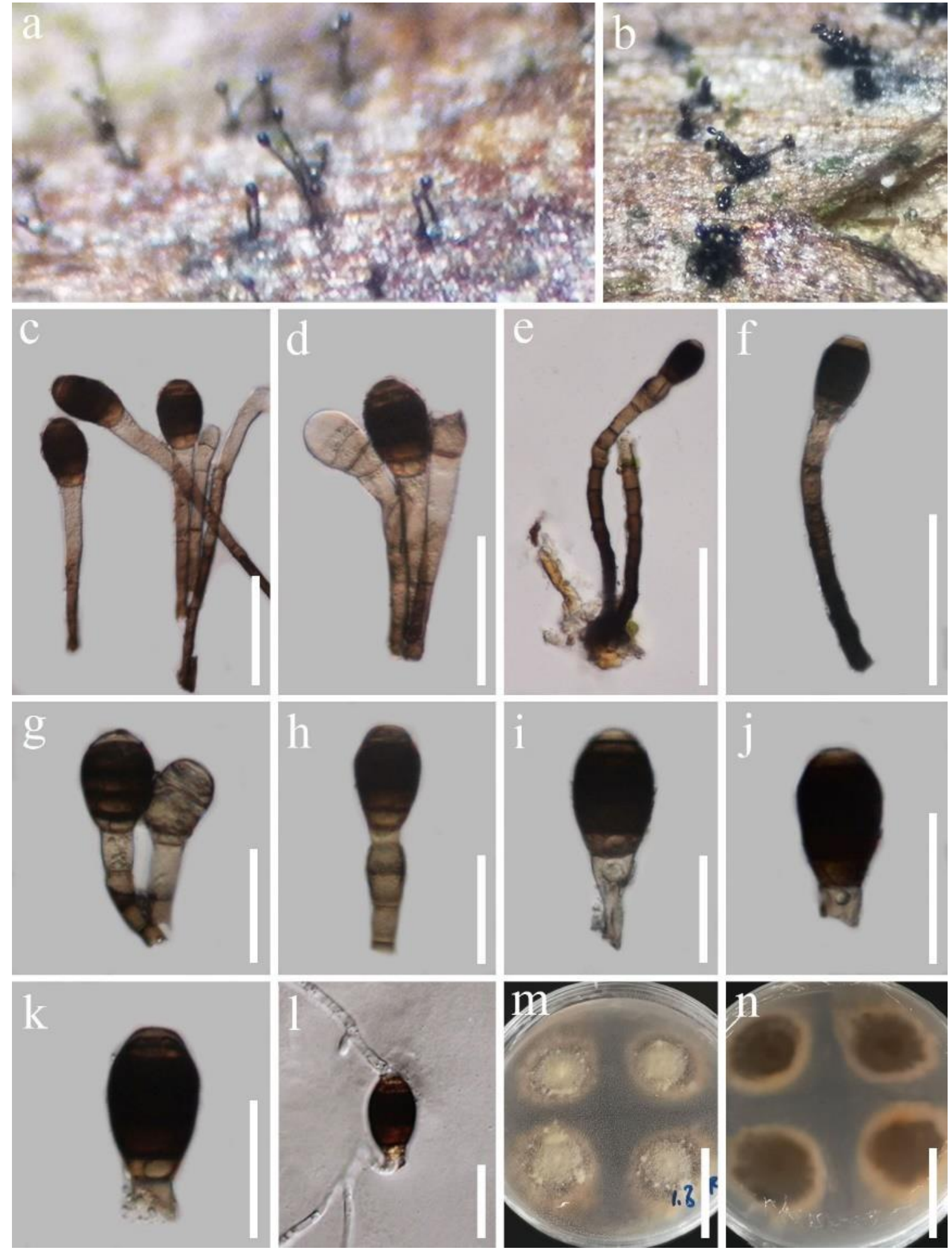

Figure 11 - Phragmocephala garethjonesii. a, b Fungus on the host surface. $\mathrm{c}-\mathrm{h}$ Conidia attached to conidiophore. $\mathrm{i}-\mathrm{k}$ Conidia. 1 Germinated conidium. $\mathrm{m}, \mathrm{n}$ Culture characters on PDA after one week $(\mathrm{m}=$ from above, $\mathrm{n}=$ from below). Scale bars: $\mathrm{c}-\mathrm{f}=50 \mu \mathrm{m}, \mathrm{g}-1=30 \mu \mathrm{m}, \mathrm{m}, \mathrm{n}=30 \mathrm{~mm}$.

Saprobic in soil. Sexual morph: Apothecia 9-20 mm broad, sessile or shortly stipitate, cupuliform, scattered, hymenium greyish-yellow when fresh, receptacle surface greyish-yellow to 
yellowish brown, finely warted, whitish to beige; Margin denticulate and a bit darker than out surface when mature. Subhymenium and medullary excipulum thin, of textura intricata, with hyaline hyphae 3.5-7.5 $\mu \mathrm{m}$ wide. Ectal excipulum 92-160 $\mu \mathrm{m}$, of textura subglobulosa/angularis, with cells $11.5-32 \times 4.5-15.5 \mu \mathrm{m}$. Asci 310-365 × 14-17 $\mu \mathrm{m}, 8$-spored, cylindrical, narrowed to the long base, without croziers, operculate, inamyloid. Paraphyses $2-3.5 \mu \mathrm{m}$ wide, filiform. Ascospores 13.5-15.5 $\times 8-9 \mu \mathrm{m}, \mathrm{Q}=1.5-1.8, \mathrm{Qm}=1.7$, hyaline, ellipsoid, smooth and thickwalled, containing two large oil guttules. Asexual morph: Undetermined.
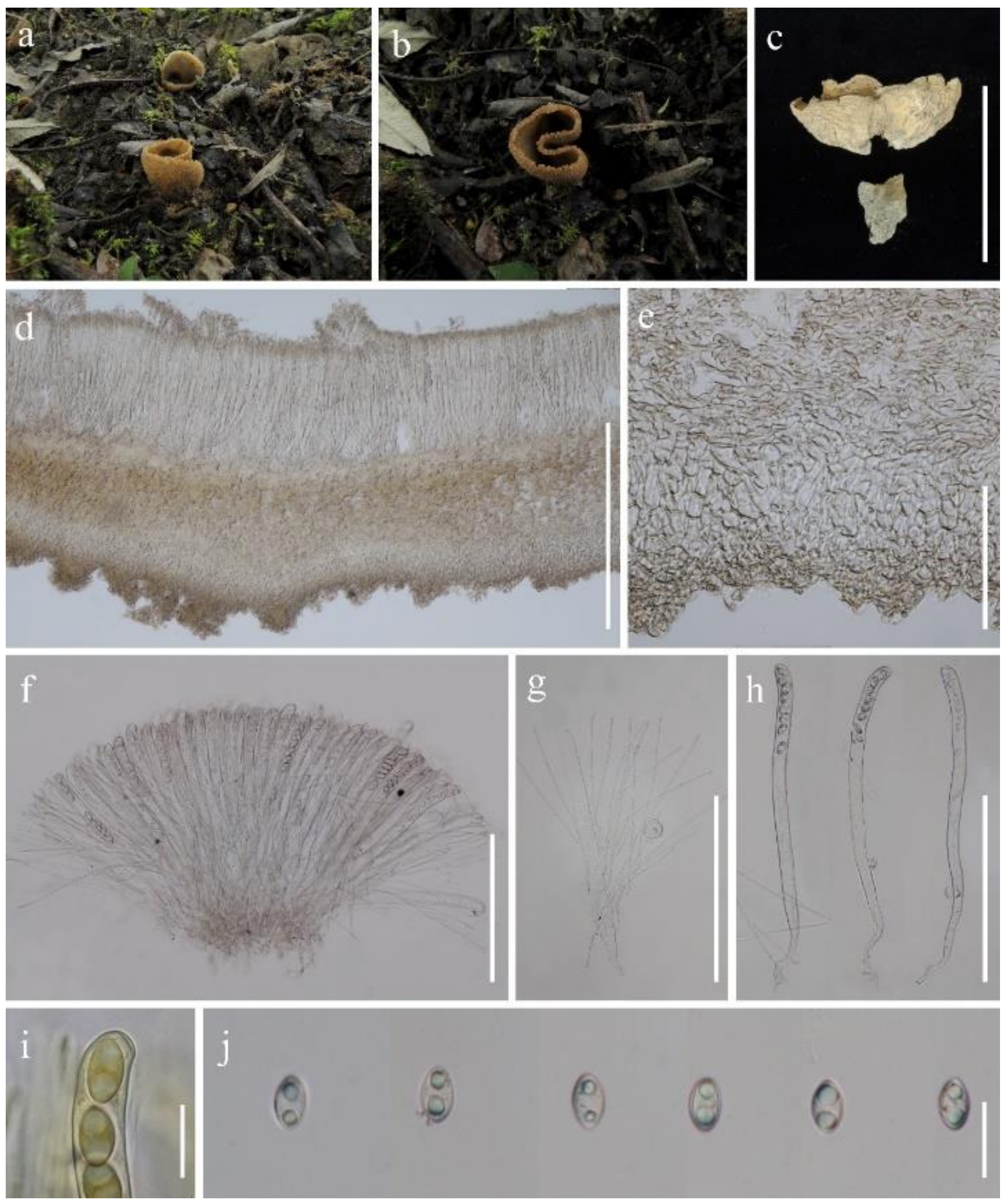

Figure 12 - Tarzetta confusa (HKAS 115755, holotype). a-c Typical mature specimens. $\mathrm{d}$ Anatomic structure of a portion of an apothecium. e Receptacle surface of pileus. $\mathrm{f}$ Asci and paraphyses. g Paraphyses. h Asci. i Upper part of ascus in Melzer's reagent. j Ascospores. Scale bars: $\mathrm{c}=20 \mathrm{~mm}, \mathrm{~d}=500 \mu \mathrm{m}, \mathrm{e}=100 \mu \mathrm{m}, \mathrm{f}-\mathrm{h}=200 \mu \mathrm{m}, \mathrm{i}-\mathrm{j}=20 \mu \mathrm{m}$. 
Material examined - China, Tibet, Nyingchi County, on soil, 18 July 2019, S. Wang (HKAS 115755, holotype). GenBank accession numbers (ITS) MZ438005 and (LSU) MZ438008.

Notes - Tarzetta ochracea, T. quercus-ilicis, T. linzhiensis and T. confusa formed four successive sister lineages with $\mathrm{ML}=100 \%$; PP $=1 \mathrm{LSU}+\mathrm{ITS}$ support. A comparison of sequence data of $T$. confusa differed by 125 ITS $(20.06 \%, 623 \mathrm{bp})$ and 25 LSU $(2.92 \%, 855 \mathrm{bp})$ base pairs with $T$. linzhiensis (Fig. 14). The species are similar in the size of apothecia, but $T$. confusa can be distinguished by its abundant prominent warts on the receptacle surface. Tarzetta confusa also differs from $T$. linzhiensis mainly by its slimmer asci and smaller ascospores. To date, only $T$. catinus and T. cupularis have been reported from China (Zhuang 2014). Zhuang (2014) indicated that these Chinese species are easily confused because their similar fruiting bodies; the apothecia of both species are between 6 to $25 \mathrm{~mm}$ diameter the shape of ascospores and structure of excipulum are key features that can be used to distinguish T. catinus from T. cupularis. However, compared with European materials, the Chinese Tarzetta species apothecia are variable in size, possibly because of different habitats and geographic locations (Zhuang 2014, Van Vooren et al. 2019). When our two new species are compared with T. catinus and T. cupularis from China, some slight differences can be seen. All four species are relatively small, with a diameter of no more than $30 \mathrm{~mm}$. However, they have very specific shaped and sized ascospores.

333. Tarzetta linzhiensis F.M. Yu, S. Wang, Q. Zhao \& K.D. Hyde, sp. nov.

Fig. 13

Index Fungorum number: IF558483; Facesoffungi number: FoF 09909

Etymology - The type location Nyingchi (China, Tibet) is given as the specific epithet.

Holotype - HKAS 115754

Saprobic in soil. Sexual morph: Apothecia 18-25 mm broad, short stipitate, cupuliform, scattered, hymenium pale cream to greyish-yellow when fresh, receptacle surface greyish-yellow to brownish-yellow, finely furfuraceous or low-warted, whitish to buff; Margin denticulate and a bit darker than out surface. Subhymenium and medullary excipulum thick, of textura intricata, with hyaline hyphae 4-9 $\mu \mathrm{m}$ wide. Ectal excipulum 70-170 $\mu \mathrm{m}$ broad, of textura subglobulosa/angularis, with cells 11-42 × 6.5-22 $\mu \mathrm{m}$. Asci 310-385 × 15-20 $\mu \mathrm{m}, 8$-spored, cylindrical, narrowed to the long base, without croziers, operculate, inamyloid. Paraphyses 2-3 $\mu \mathrm{m}$ wide, septate, straight, filiform. Ascospores [20/1/1, in $\left.\mathrm{H}_{2} \mathrm{O}\right](17)$ 18.5-22.5 (23.5) $\times(9)$ 10-13.5 $\mu \mathrm{m}, \mathrm{Q}=1.4-2.6, \mathrm{Qm}=1.68$, uniseriate, hyaline, ellipsoid, smooth-walled, containing two large oil guttules that fuse into one larger guttule at maturity. Asexual morph: Undetermined.

Material examined - China, Tibet, Nyingchi County, in soil, 18 July 2019, S. Wang (HKAS 115754, holotype). GenBank accession numbers ITS (MZ438004) and LSU (MZ438007).

Notes - Phylogenetic analyses of the combined LSU and ITS sequence dataset showed that Tarzetta linzhiensis formed a individual branch with ML: 87\%, PP: 1.00 support, sister to the clade comprising T. ochracea and T. quercus-ilicis (Fig. 14). In contrast to T. linzhiensis, T. quercusilicis has smaller asci $(250-300 \times 13-18 \mu \mathrm{m})$, and thicker paraphyses $(4-5 \mu \mathrm{m}$ diameter) (Van Vooren et al. 2019). Tarzetta ochracea can be distinguished by the absence of a true stipe, and its larger apothecia (can reach $50 \mathrm{~mm}$ diameter) and slightly larger ascospores 19-25 × 11-14 $\mu \mathrm{m}$ (Van Vooren et al. 2019).

\section{A key to Chinese Tarzetta species}

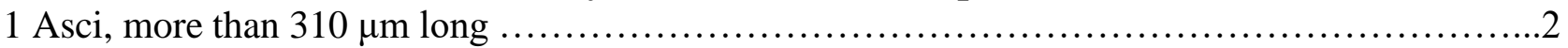

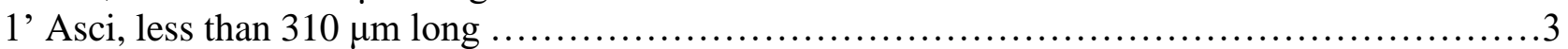

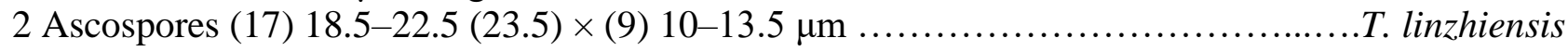

2' Ascospores 13.5-15.5 × 8-9 $\mu \mathrm{m}$................................................ confusa

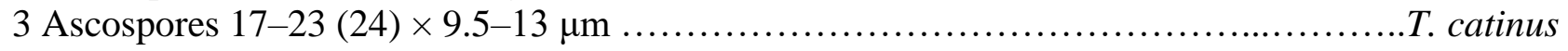

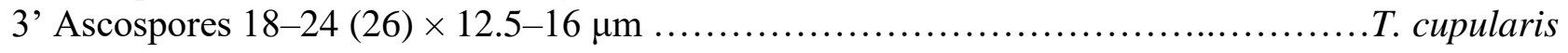



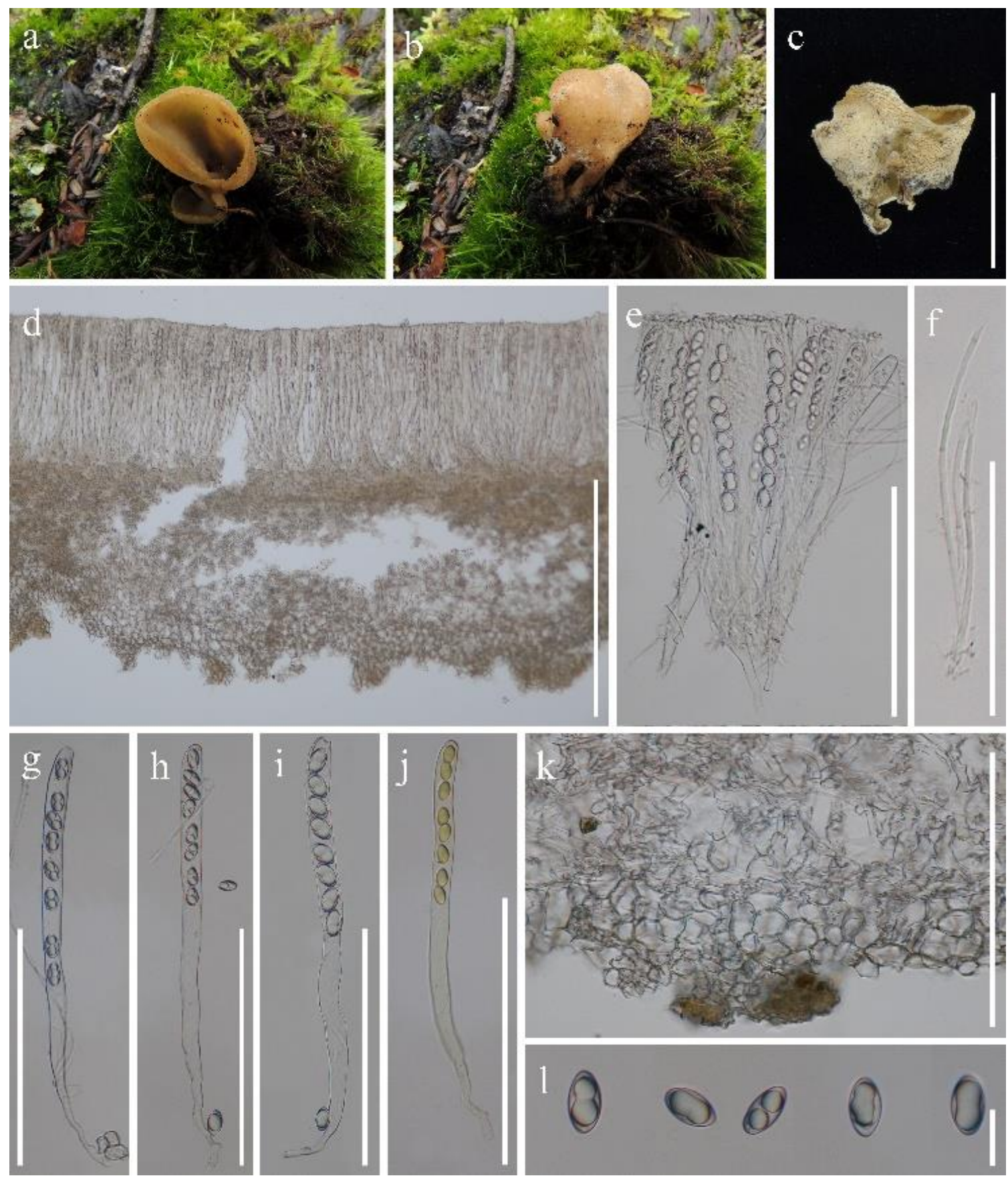

Figure 13 - Tarzetta linzhiensis (HKAS 115754, holotype). a-c Typical mature specimens. $\mathrm{d}$ Anatomic structure of a portion of an apothecium. e Asci and paraphyses. f Paraphyses. $\mathrm{g}-\mathrm{j}$ Asci ( $\mathrm{j}$ in Melzer's reagent). $\mathrm{k}$ Receptacle surface of pileus. 1 Ascospores. Scale bars: $\mathrm{c}=20 \mathrm{~mm}$, $\mathrm{d}=500 \mu \mathrm{m}, \mathrm{e}, \mathrm{g}-\mathrm{k}=200 \mu \mathrm{m}, \mathrm{f}=100 \mu \mathrm{m}, \mathrm{l}=20 \mu \mathrm{m}$.

334. Distoseptispora chinensis X. Tang, Jayaward., J.C. Kang \& K.D. Hyde, sp. nov.

Fig. 15

Index Fungorum number: IF558531; Facesoffungi number: FoF 09941

Etymology - 'chinensis' named after the country from which the holotype was found.

Holotype - GZAAS21-0380

Saprobic on decaying wood in terrestrial habitats. Sexual morph: Undetermined. Asexual morph: Colonies effuse, brown or dark brown, hairy. Mycelium mostly immersed, branched, septate, smooth, pale brown to brown. Conidiophores $16.5-44 \times 5.5-9 \mu \mathrm{m}(\overline{\mathrm{x}}=34 \times 7 \mu \mathrm{m}, \mathrm{n}=30)$, macronematous, mononematous, mid-olivaceous to brown, solitary, 1-4-septate, erect, straight or flexuous, unbranched, smooth, cylindrical, truncate at the apex. Conidiogenous cells holoblastic, monoblastic, integrated, terminal, determinate, brown to dark brown, smooth, cylindrical. Conidia 
81-283 × 10-19 $\mu \mathrm{m}(\overline{\mathrm{x}}=201 \times 15 \mu \mathrm{m}, \mathrm{n}=30)$ acrogenous, solitary, obclavate or lanceolate, rostrate, straight or slightly curved, multi-distoseptate, up to 40-distoseptate, guttulate, olivaceous to dark brown, tapering towards the rounded apex 4.5-9 $\mu \mathrm{m}(\overline{\mathrm{x}}=7 \mu \mathrm{m}, \mathrm{n}=30)$, truncate at the base, slightly constricted at septa, smooth-walled, rounded at apex, with a truncate base and faintly to heavily pigmented scar.

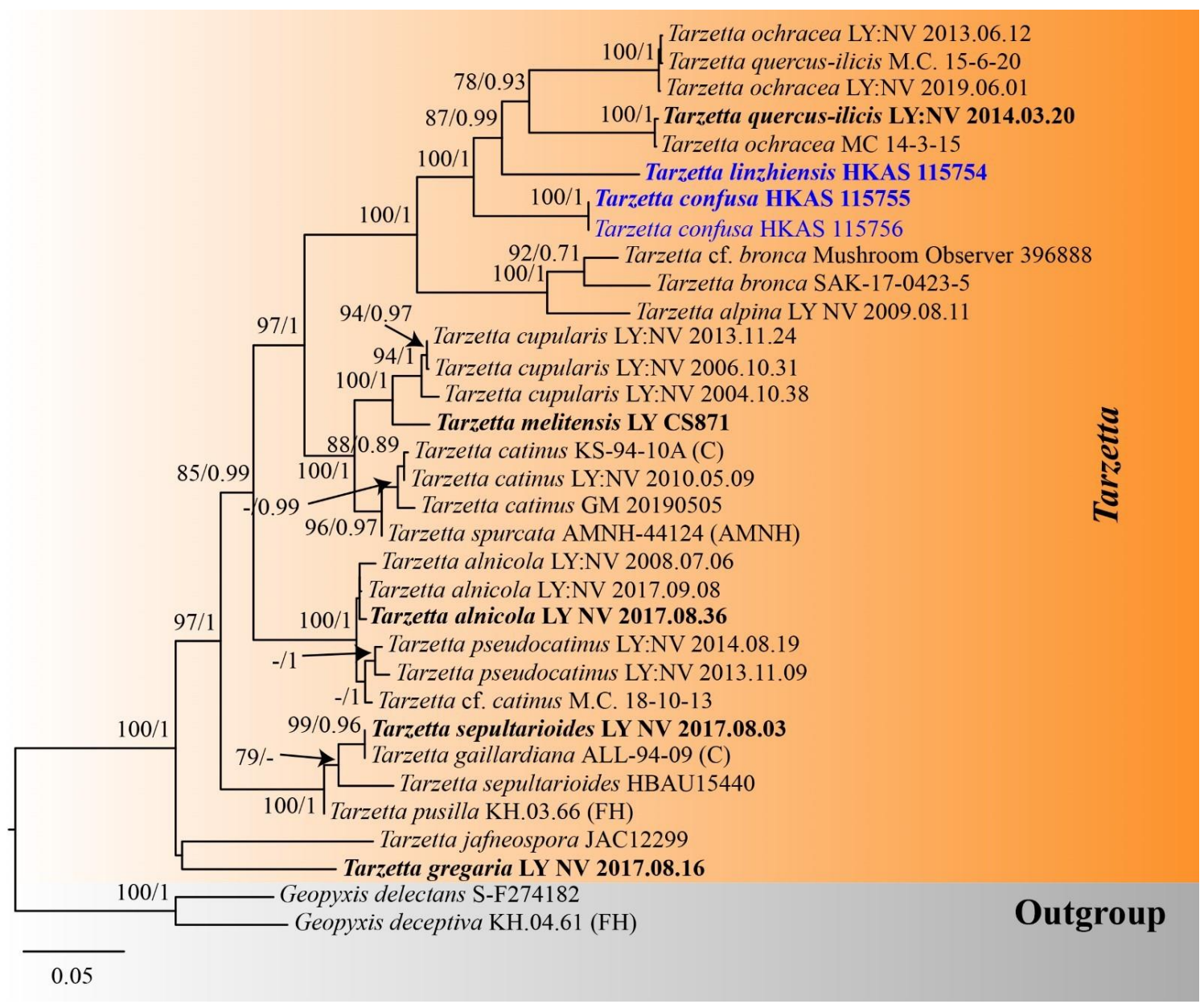

Figure 14 - Phylogram generated from maximum likelihood analysis based on combined LSU and ITS sequence data representing the species of Tarzetta and related taxa. Thirty-three taxa are included in the combined analyses, which comprised 1522 characters (LSU: 864, ITS: 658) after alignment. The best scoring RAxML tree with a final likelihood value of -8329.803766 is presented. The matrix had 581 distinct alignment patterns, with $17.07 \%$ of undetermined characters or gaps. Estimated base frequencies were as follows: $\mathrm{A}=0.263606, \mathrm{C}=0.225986, \mathrm{G}=0.280220$, $\mathrm{T}=0.230188$; substitution rates: $\mathrm{AC}=1.633048, \mathrm{AG}=2.433833, \mathrm{AT}=1.538952, \mathrm{CG}=1.259865$, $\mathrm{CT}=4.493309, \mathrm{GT}=1.000000$; gamma distribution shape parameter $\alpha=0.224555$. Bootstrap support values for ML equal to or greater than $75 \%$ and PP equal to or greater than 0.95 are given above the nodes. Geopyxis deceptive (FH KH.04.61) and G. delectans (S-F274182) were used as outgroup taxa. The newly generated sequences are indicated in bule and bold for type.

Culture characteristics - Colony grown on PDA, circular, fluffy, white, dense, white mycelium, but olivaceous in the center, slightly pigmented. In reverse, olivaceous, brown at the center, lightly brown at the entire margin, breaking in the center.

Material examined - China, Guizhou Province, Longli, on decaying wood submerged in a freshwater stream, 3 December 2020, Jian Ma, SZ9 (GZAAS21-0380, holotype), ex-type living culture, GZCC21-0665. GenBank accession numbers (ITS) MZ474871, (LSU) MZ474867, (SSU) MZ474874 and (tef-1) MZ501609. 
Notes - Distoseptispora chinensis forms a sister clade to D. tectonigena with $88 \% \mathrm{ML}, 71 \%$ MP and 0.99 PP support values (Fig. 17). However, D. chinense differs from D. tectonigena in having smaller conidiophores $(16.5-44 \times 5.5-9 \mu \mathrm{m}, 1-4$-septate vs $110 \times 5-11 \mu \mathrm{m}, 2-6$-septate $)$ and larger conidia $(81-283 \times 10-19 \mu \mathrm{m}$ vs $148-225 \times 11-12 \mu \mathrm{m})$. Distoseptispora tectonigena is distinct from $D$. chinensis by its unique characters on percurrently proliferating 5-10 times at apex. Based on a pairwise nucleotide comparison of ITS and LSU, D. chinensis differs from D. tectonigena in 11/ 562 bp (1.9\%) for ITS and 3/ 837 bp (0.3\%) for LSU. Based on morphology and phylogeny can be considered as a distinct species according to the guidelines of Jeewon \& Hyde (2016).

335. Distoseptispora guizhouensis X. Tang, Jayaward., J.C. Kang \& K.D. Hyde, sp. nov. Fig. 16 Index Fungorum number: IF558532; Facesoffungi number: FoF 09942

Etymology - 'guizhouensis' named after the city from which the holotype was found.

Holotype - GZAAS21-0381

Saprobic on decaying wood. Sexual morph: Undetermined. Asexual morph: Hyphomycetous. Colonies superficial, effuse, hairy, gregarious, brown to dark brown. Mycelium mostly immersed on host substrate, septate, branched, pale brown to dark brown. Conidiophores $21-50 \times 4-9 \mu \mathrm{m}(\overline{\mathrm{x}}=$ $32 \times 7 \mu \mathrm{m}, \mathrm{n}=30$ ), macronematous, mononematous, erect, cylindrical, Singly or in groups, straight or slightly flexuous, septate, slightly constricted at septa, wide at the base, unbranched, brown to dark brown, thin-walled, smooth. Conidiogenous cells holoblastic, monoblastic, integrated, determinate, terminal, subcylindrical, brown, smooth. Conidia 90-273 $\times 15-21 \mu \mathrm{m}(\overline{\mathrm{x}}=178 \times 18$ $\mu \mathrm{m}, \mathrm{n}=30$ ), acrogenous, solitary, thin-walled, smooth, obclavate, slightly curved to curved, rarely slightly constricted at septa, 10-38- distoseptate, brown to dark brown, usually paler towards apex, rounded at apex, with a truncate base and faintly to heavily pigmented scar.

Culture characteristics - Colony on PDA, circular, fluffy, white, dense, light yellow mycelium in the center, but becoming sparse and paler at the entire margin, pigment. In reverse, olivaceous, brown at the center, lightly brown at the entire margin. In reverse dark gray.

Material examined - China, Guizhou Province, Guiyang City, Xiaochehe Park, on decaying wood in terricolous habitat, 29 March 2020, Xia Tang, XCH21 (GZAAS21-0381, holotype), extype living culture, GZCC21-0666. GenBank accession numbers (ITS) MZ474868, (LSU) MZ474869, (SSU) MZ474870, (rpb2) MZ501611 and (tef-1) MZ501610.

Notes - Distoseptispora guizhouensis forms a sister taxon of an uncultured fungus clone (C1_AF3) with 92\% ML, 89\% MP and 1 PP support (Fig. 17). However, C1_AF3 cannot provide any morphological features, but phylogenetic analysis has shown C1_AF3 belongs to the genus Distoseptispora. Thus, we consider D. guizhouensis as a novel species according to the guidelines of Jeewon \& Hyde (2016).

336. Neospadicoides bambusicola J.Y. Zhang, Y.Z. Lu \& K.D. Hyde, sp. nov.

Fig. 18

Index Fungorum number: IF558528, Facesoffungi number: FoF 09899

Etymology - 'bambusicola' Name reflects the host bamboo.

Holotype - MFLU 21-0085

Saprobic on dead bamboo culms. Sexual morph: Undetermined. Asexual morph: Hyphomycetous. Colonies on natural substrate superficial, effuse, hairy, brown, velvety. Mycelium partly immersed, partly superficial, composed of pale brown to brown, septate, branched hyphae. Conidiophores $(781-) 1027-1296 \times 3.5-5 \mu \mathrm{m}(\overline{\mathrm{x}}=1131 \times 4.5 \mu \mathrm{m}, \mathrm{n}=10)$ macronematous, mononematous, cylindrical, erect, solitary or in groups, septate, straight or slight flexuous, brown, unbranched, paler towards the apex, thick-walled, smooth-walled. Conidiogenous cells 6-8.5 $\times$ 3.5-5 $\mu \mathrm{m}(\overline{\mathrm{x}}=7 \times 4.3 \mu \mathrm{m}, \mathrm{n}=15)$, holoblastic, polytretic, intercalary, terminal. subhyaline when young, pale brown when mature. Conidia acrogenous or acropleurogenous, fusiform, obovoid, septate. Conidia 15.5-22 $\times 5-7.5 \mu \mathrm{m}(\overline{\mathrm{x}}=18 \times 6 \mu \mathrm{m}, \mathrm{n}=25)$, solitary, obovoid, rounded at the apex, truncate at the base, 2-3-septate, thick-walled, smooth-walled, guttulate, subhyaline when young, rather dark brown to pale brown from uppers cell to base cells when mature. 

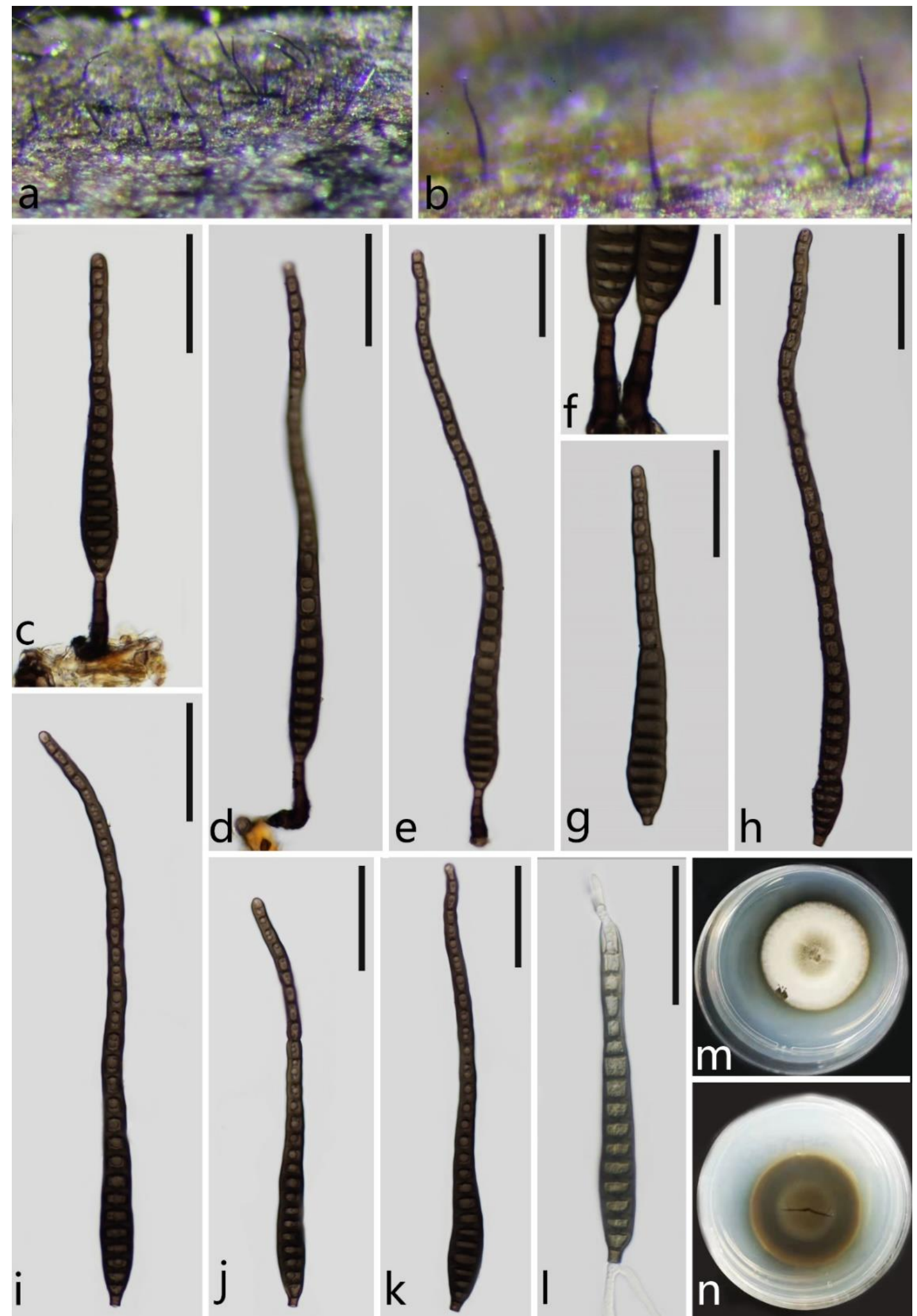

g
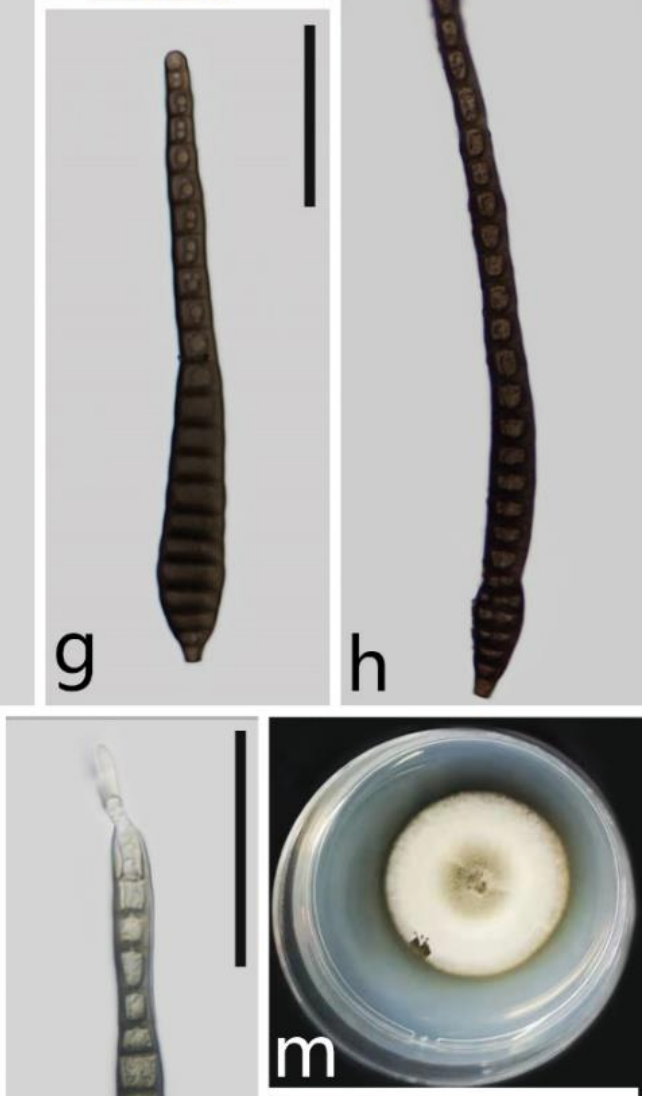

Figure 15 - Distoseptispora chinensis (Holotype: GZAAS21-0380). a, b Colonies on submerged wood. c-f Conidiophores, conidiogenous cell bearing conidia. g-k Conidia. 1 Germinated conidium. m, $\mathrm{n}$ Colony on PDA (from above, from below). Scale bars: $\mathrm{c}-\mathrm{e}, \mathrm{h}-1=50 \mu \mathrm{m}, \mathrm{f}=20 \mu \mathrm{m}$. 

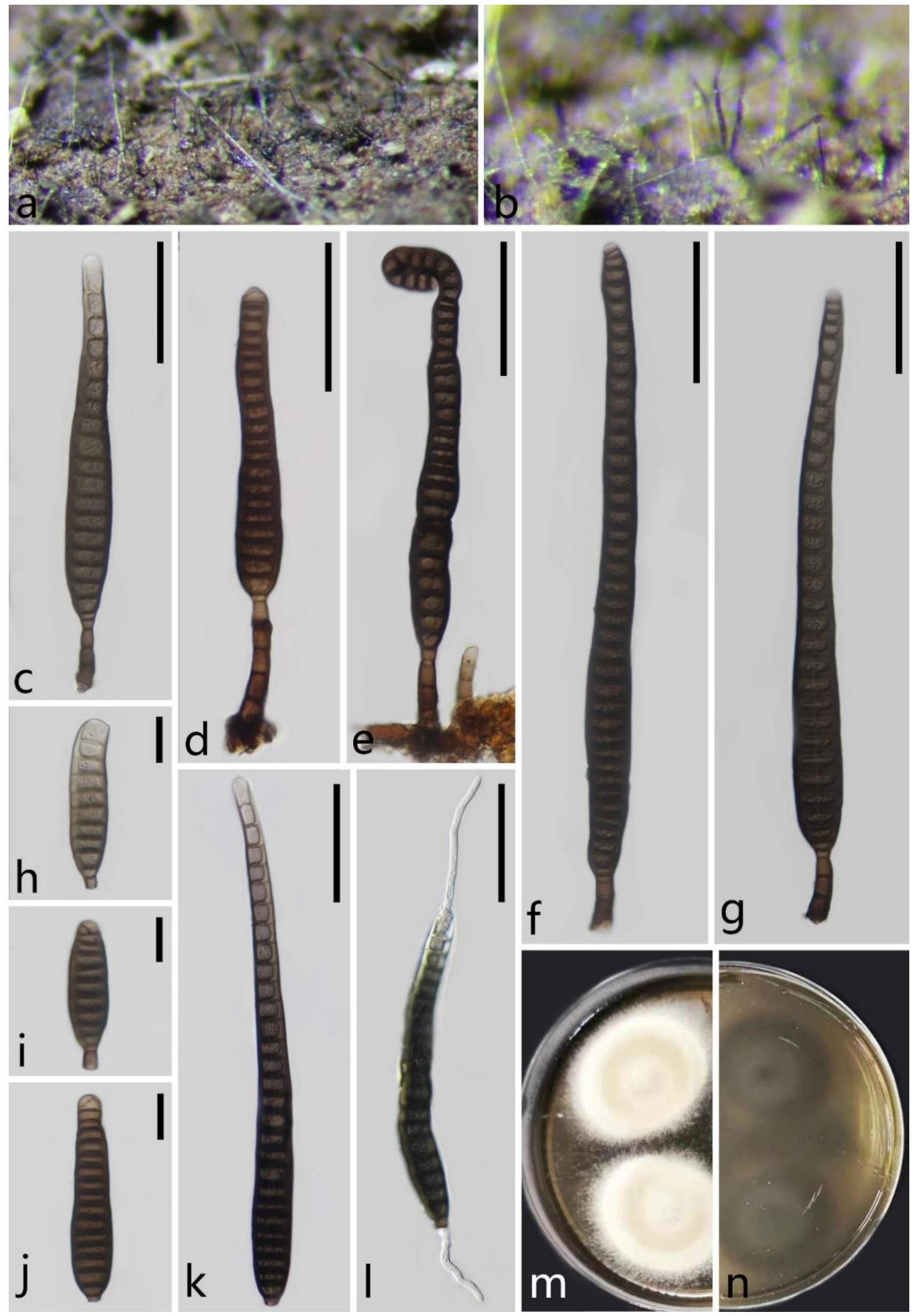

Figure 16 - Distoseptispora guizhouensis (Holotype: GZAAS21-0381). a, b Colonies on dead wood. c-e Conidiophores, conidiogenous cell with conidia. $\mathrm{f}$, g Conidiogenous cell bearing conidia. $\mathrm{h}-\mathrm{k}$ Conidia. 1 Germinated conidia. m, n Colony on PDA (up-front, down-reverse). Scale bars: c-g, $\mathrm{k}, \mathrm{l}=50 \mu \mathrm{m}, \mathrm{h}-\mathrm{j}=20 \mu \mathrm{m}$. 


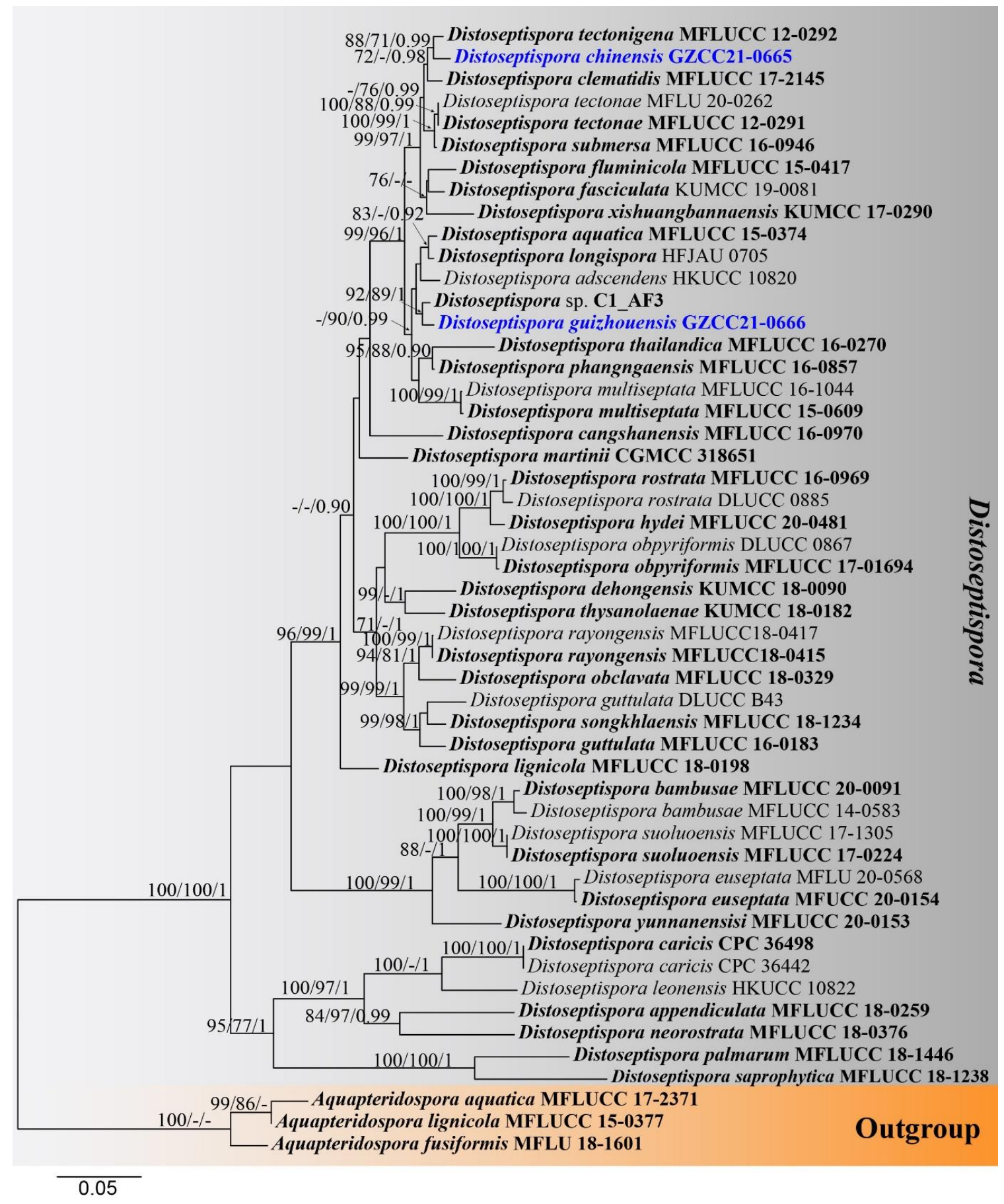

Figure 17 - Phylogenetic tree derived from maximum likelihood analysis of a combined ITS, LSU, SSU, rpb2 and tef-1 genes of 51 sequences and the aligned dataset was comprised of 4351 characters including gaps (ITS: 1-582, LSU: 583-1418, SSU $=1419-2428, r p b 2=2429-3469$, tef- 1 $=3470-4351$ ). The average standard deviation of the split frequencies of the BI analysis was 0.009761. A best scoring RAxML tree was established with a final ML optimization likelihood value of -23562.243211. The matrix had 1449 distinct alignment patterns with $41.65 \%$ undetermined characters or gaps. Estimated base frequencies were found to be: $\mathrm{A}=0.244375, \mathrm{C}=$ $0.256998, \mathrm{G}=0.280488, \mathrm{~T}=0.218138$; substitution rates $\mathrm{AC}=1.271118, \mathrm{AG}=3.052479, \mathrm{AT}=$ $1.198164, \mathrm{CG}=0.768793, \mathrm{CT}=6.821388, \mathrm{GT}=1.000000 ;$ proportion of invariable sites $=$ 0.706734 and gamma distribution $=0.187087$. For the MP analysis, 4351 characters remained unchanged, 265 were variable and parsimoniously uninformative, while 1011 were parsimoniously informative. The most parsimonious tree showed the following values: $\mathrm{TL}=3698, \mathrm{CI}=0.525, \mathrm{RI}=$ $0.725, \mathrm{RC}=0.381, \mathrm{HI}=0.475$. Aquapteridospora fusiformis (MFLU 18-1601), Aquapteridospora 
lignicola (MFLUCC 15-0377) and Aquapteridospora aquatica MFLUCC 17-2371) were used as outgroup taxa. Numbers above branches are the bootstrap statistics percentages for ML and MP (left, middle) and Bayesian posterior probabilities (right). Branches with bootstrap values $\geq 70 \%$ are shown at each branch and the bar represents 0.05 substitutions per nucleotide position. Hyphen (-) represents support values $\leq 70 \% / 0.95$. Ex-type strains are in black bold, newly generated sequence is indicated in blue and bold for new taxa.
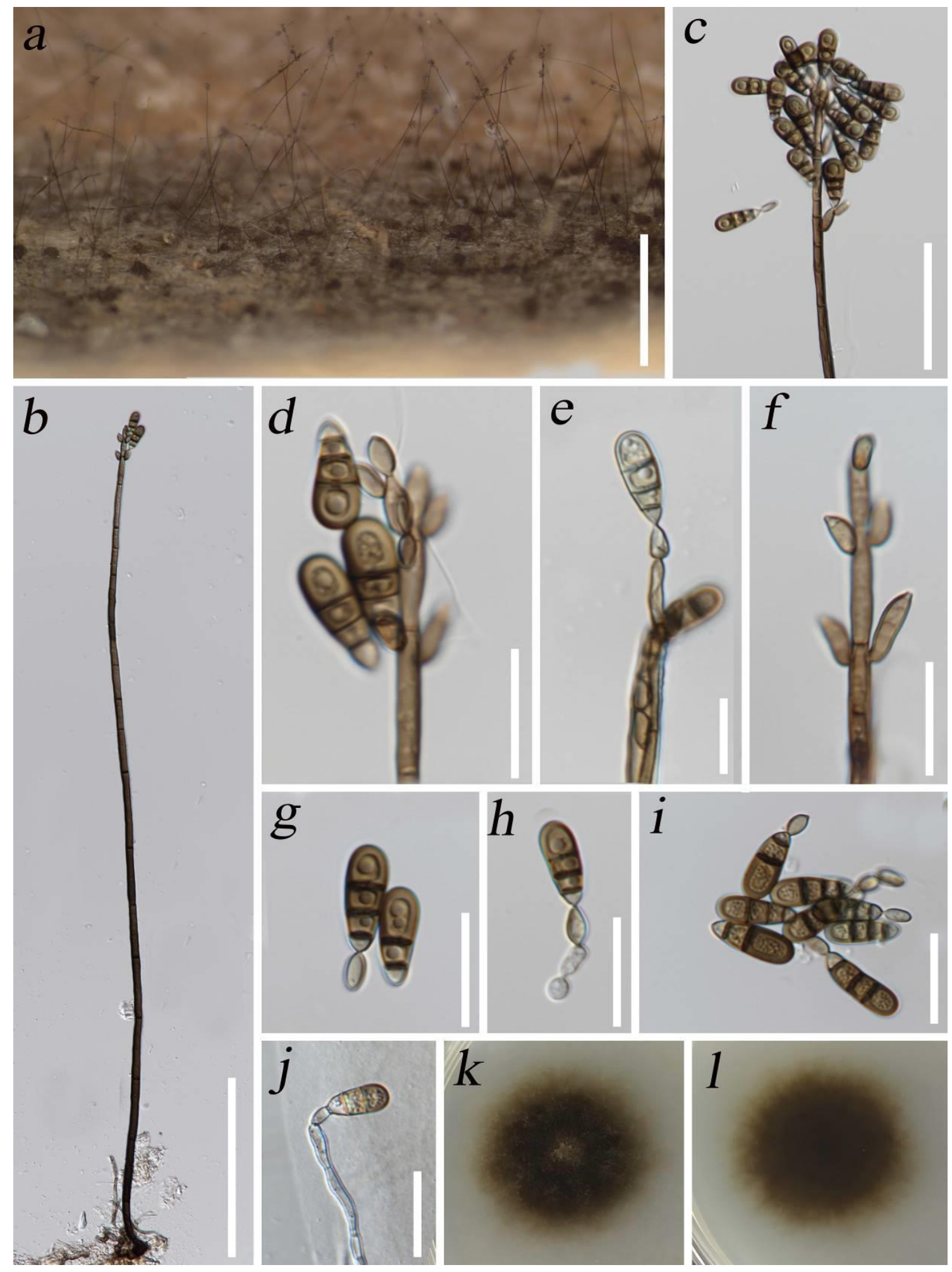

Figure 18 - Neospadicoides bambusicola (MFLU 21-0085, holotype). a Colonies on the host. b Conidiophore. $\mathrm{c}-\mathrm{i}$ Conidiogenous cells with conidia. $\mathrm{j}$ Germinating conidium. $\mathrm{k}-\mathrm{l}$ Culture on PDA from surface and reverse. Scale bars: $a=1000 \mu \mathrm{m}, b=150 \mu \mathrm{m}, c=50 \mu \mathrm{m}, d-j=20 \mu \mathrm{m}$. 
Culture characteristics - Conidia germinating on PDA within 12 hours at room temperature. The hyaline germ tube germinated from the base of conidia. Colonies growing on PDA at $25^{\circ} \mathrm{C}$, reaching $1.8 \mathrm{~cm}$ diameter in 2 weeks. Mycelia superficial to immersed, circular, entire edge with marginal hyphae immersed, flat, velvety thin, dark brown.

Material examined - Thailand, Chiang Mai Province, Mushroom Research Centre (19.1176083, 98.7333179), on dead bamboo culms in land, 11 September 2020, H.W. Shen, Y205(2) (MFLU 21-0085, holotype). GenBank accession numbers: (LSU) MZ435868, (ITS) MZ435866.

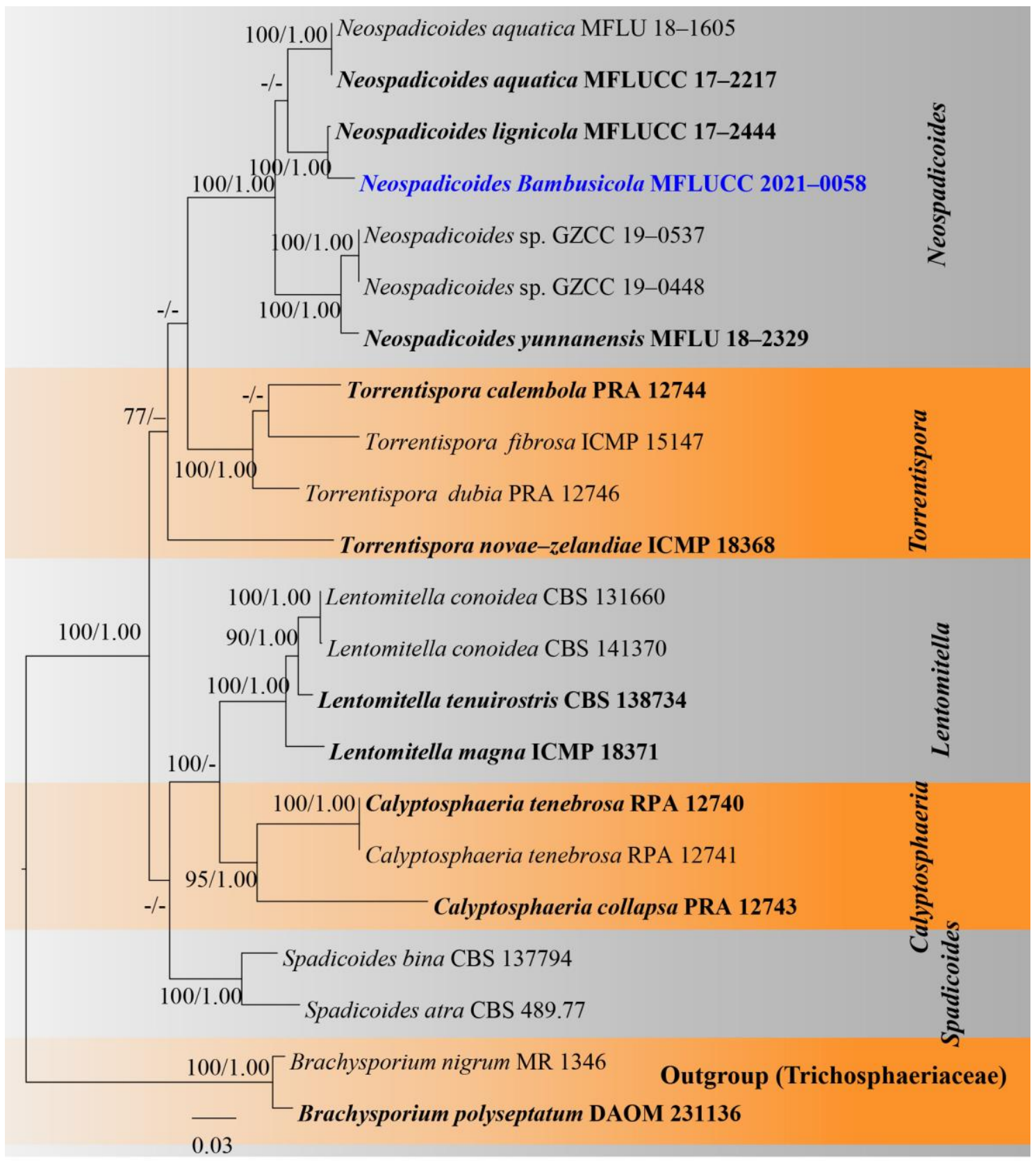

Figure 19 - Phylogenetic tree derived from maximum likelihood analysis of a combined LSU, ITS, $r p b 2$ and tef- 1 genes of 22 sequences and the aligned dataset was comprised of 4850 characters including gaps (LSU: 1-1907, ITS: 1908-2570, rpb2 $=2571-3798$ and tef-1: 3799-4850). The average standard deviation of the split frequencies of the BI analysis was 0.007799 . A best scoring RAxML tree was established with a final ML optimization likelihood value of -19207.266136. The matrix had 1308 distinct alignment patterns with $37.88 \%$ undetermined characters or gaps. Estimated base frequencies were found to be: $\mathrm{A}=0.249310, \mathrm{C}=0.245781, \mathrm{G}=0.281810, \mathrm{~T}=$ 
0.223099; substitution rates: $\mathrm{AC}=1.312714, \mathrm{AG}=2.959519, \mathrm{AT}=1.340908, \mathrm{CG}=1.445817$, $\mathrm{CT}=6.163706, \mathrm{GT}=1.000000$; proportion of invariable sites $=0.741443$ and gamma distribution $=0.147418$. Brachysporium nigrum MR 1346 and B. polyseptatum DAOM 231136 were used as outgroup taxa. Numbers above branches are the bootstrap statistics percentages (left) and Bayesian posterior probabilities (right). Branches with bootstrap values $\geq 70 \%$ are shown at each branch and the bar represents 0.03 substitutions per nucleotide position. Hyphen (-) represents support values $\leq$ $70 \% / 0.95$. Ex-type strains are in black bold, newly generated sequence is indicated in blue and bold.

Notes - Neospadicoides was introduced by Luo et al. (2019) to accommodate three freshwater species, N. aquatica, N. lignicola (as type species) and $N$. yunnanensis (Luo et al. 2019). Phylogenetic analyses of the combined LSU, ITS, $r p b 2$ and SSU sequence dataset confirmed that $N$. bambusicola belonging to Neospadicoides, where it is sister to N. lignicola with $100 \%$ BS and 1.00 PP support (Fig. 19). A comparison of nucleotide base pairs between our new collection of Neospadicoides bambusicola and N. lignicola (MFLUCC 17-2444) showed that they differ by $24 / 500$ bp (5\%) in ITS and 24/500 bp (5\%). Neospadicoides bambusicola is similar to N. lignicola in having unbranched, septate, brown conidiophores, holoblastic, intercalary, terminal conidiogenous cells and obovoid, septate conidia. However, $N$. bambusicola differs from $N$. lignicola in having significantly longer conidiophores [(781-)1027-1296 $\mu \mathrm{m}$ vs (70-)134-276($303) \mu \mathrm{m}]$ and guttulate and smaller conidia $15.5-22 \times 5-7.5 \mu \mathrm{m}$ vs 20-24 ×9-13 $\mu \mathrm{m}$. Therefore, $N$. bambusicola is introduced here as the fourth new species of Neospadicoides based on phylogeny and morphological comparison, combined with the guidelines for species delineation described in Jeewon \& Hyde (2016).

337. Hymenopleella agaves I.C. Senan., \& K.D. Hyde, sp. nov.

Fig. 20

Index Fungorum number: IF558478; Facesoffungi number: FoF 09904

Etymology - Species epithet based on the host genus on which the fungus was collected.

Holotype - HKAS 115763

Saprobic on dead leaves of Agave sp. Sexual morph: Undetermined. Asexual morph: Conidiomata scattered, acervular, semi-immersed, black. Conidiophores reduced to conidiogenous cells. Conidiogenous cells 3.5-10 $\times 1-3 \mu \mathrm{m}(\overline{\mathrm{x}}=6 \times 2.5 \mu \mathrm{m}, \mathrm{n}=30)$, discrete, sub-cylindrical, hyaline to olivaceous, smooth. Conidia $15-20 \times 2-3 \mu \mathrm{m}(\overline{\mathrm{x}}=18 \times 2.5 \mu \mathrm{m}, \mathrm{n}=30)$, cylindrical, subcylindrical, straight or slightly curved, olivaceous, 1-(3)-septate, smooth, fairly thick-walled, without constriction at the septa,; basal cell conical, thin-walled, hyaline to pale brown, $3-5 \mu \mathrm{m}(\overline{\mathrm{x}}$ $=3.5 \mu \mathrm{m})$ long; median cells, cylindrical, pale brown, together $15-25 \mu \mathrm{m}(\overline{\mathrm{x}}=21 \mu \mathrm{m})$ long, each cell 8-15 $\mu \mathrm{m}$ long; apical cell conical, hyaline to pale brown, 3-6 $\mu \mathrm{m}(\overline{\mathrm{x}}=5.5 \mu \mathrm{m})$ long; apical and basal appendages absent.

Culture characteristics - Colonies on potato dextrose agar (PDA) reaching about $2 \mathrm{~cm}$ diam after 7 days at $18^{\circ} \mathrm{C}$, flat with entire edge, white, aerial mycelia appear as woolly clots, reverse offwhite.

Material examined - China, Guangdong Province, Shenzhen, Nanshan District, Mountain Yangtai Forest Park, 22 $39^{\prime} 21.26^{\prime \prime N} 113^{\circ} 57^{\prime} 18.53^{\prime \prime}$, live leaves of Agave sp. (Asparagaceae), 15 September 2018, IC. Senanayake, SI 17 (HKAS 115763, holotype), ex-type culture, ZHKUCC 2100072. GenBank accession numbers (ITS) MZ420208, (LSU) MZ420203, (rpb2) MZ419853 and (tef-1) MZ419852.

Notes - Phylogenetic analysis of combined ITS, LSU, rpb2 and tef-1 genes (Fig. 21) showed that our Hymenopleella strain is phylogenetically closely related with $H$. subcylindrica and $H$. endophytica. However, our strain is distinct forming a sub-clade with MP/BI = 97/1 support values. Our strain is different from $H$. subcylindrica and $H$. endophytica having oval to cylindrical conidia without appendages and lacking conidiophores (Jaklitsch et al. 2016, Liu et al. 2019, Voglmayr et al. 2019). 

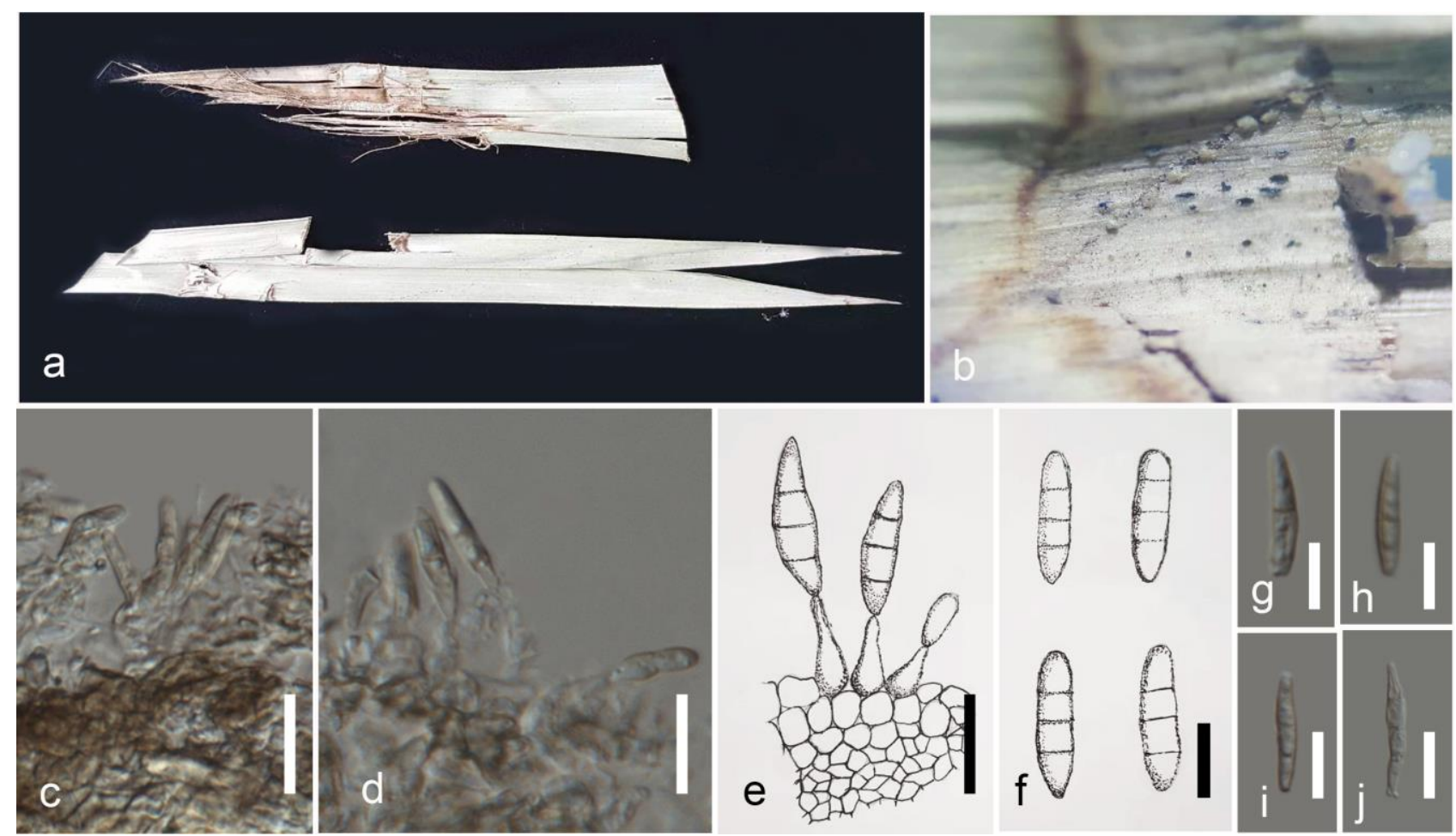

Figure 20 - Hymenopleella agaves (HKAS 115763, holotype). a Specimen. b Conidiomata on substrate. $\mathrm{c}-\mathrm{e}$ Conidia attached to conidiogenous cells. $\mathrm{f}-\mathrm{j}$ Conidia. Scale bars: $\mathrm{c}-\mathrm{e}=30 \mu \mathrm{m}$, $\mathrm{f}-\mathrm{j}=15 \mu \mathrm{m}$.

338. Synnemapestaloides shangrilaensis L. Lu \& S. Tibpromma, sp. nov. Index Fungorum number: IF558258; Facesoffungi number: FoF 09893

Fig. 22

Etymology - 'shangrilaensis' reference to the host location, Shangri-La, where the holotype was collected.

Holotype - HKAS 113188

Saprobic on dead leaves. Sexual morph: Undetermined. Asexual morph: Colonies solitary or clustered, brown to black, covering most of the leaf lamina, conspicuous on surface, rough-walled, initially flat black spots and swollen when mature, without papilla. Conidiomata $400 \times 100 \mu \mathrm{m}$, immersed, under leaf lamina, oval in outline, the host cuticle, which becomes raised then irregularly ruptures laterally or radially to release black masses of conidia. Conidiogenesis cells 10 $15 \times 1-2 \mu \mathrm{m}$, holoblastic, cylindrical to slightly ampulliform, hyaline, smooth, thin-walled. Conidia 10-15 $\times 5-7 \mu \mathrm{m},(\overline{\mathrm{x}}=13 \times 6.5 \mu \mathrm{m}, \mathrm{n}=20)$, pyriform, $0-4$-septate, not constricted at the septa, smooth-walled, 3-septate; apical cell 4-6 $\times 1-3 \mu \mathrm{m},(\overline{\mathrm{x}}=4.9 \times 2 \mu \mathrm{m}, \mathrm{n}=10)$, obtuse, thick-walled, hyaline, lacking appendages; basal cell $2-4 \times 3-5 \mu \mathrm{m},(\overline{\mathrm{x}}=3.3 \times 3.7 \mu \mathrm{m}, \mathrm{n}=10)$, obconic, thinwalled, subhyaline, appendages absent; two median cells $5-6 \times 1-4 \mu \mathrm{m},(\overline{\mathrm{x}}=5.6 \times 2.6 \mu \mathrm{m}, \mathrm{n}=10)$, doliiform to subcylindrical, moderately thick-walled, brown to black; penultimate cell 4-5 $\times 2-4$ $\mu \mathrm{m},(\overline{\mathrm{x}}=4.7 \times 3.2 \mu \mathrm{m}, \mathrm{n}=10)$, subcylindrical, short, thin-walled, hyaline; antepenultimate cell 5-6 $\times 0.5-2 \mu \mathrm{m},(\overline{\mathrm{x}}=5.4 \times 1.1 \mu \mathrm{m}, \mathrm{n}=10)$, subcylindrical, thick-walled, hyaline.

Culture characteristics - Ascospores germinated within 12 hours on MEA. Colonies on MEA reaching $50 \mathrm{~mm}$ diam, after three months at room temperature $\left(20^{\circ} \mathrm{C}\right)$. Orange-brown in the middle, white at the edges, obvious cracks, sparse and short aerial hyphae, a small amount of white flocs in the middle, and uneven edges.

Material examined - China, Shangri-La, Yunnan Province, on dead leaves of undetermined host, 29 August 2020, S. Tibpromma, Sh-LA-14 (HKAS113188, holotype), ex-type living culture KUMCC 21-0003. GenBank accession numbers (ITS) MZ387995, (LSU) MZ387994, (rpb2) MZ389340, (tub2) MZ389341 and (tef-1) MZ399720. 


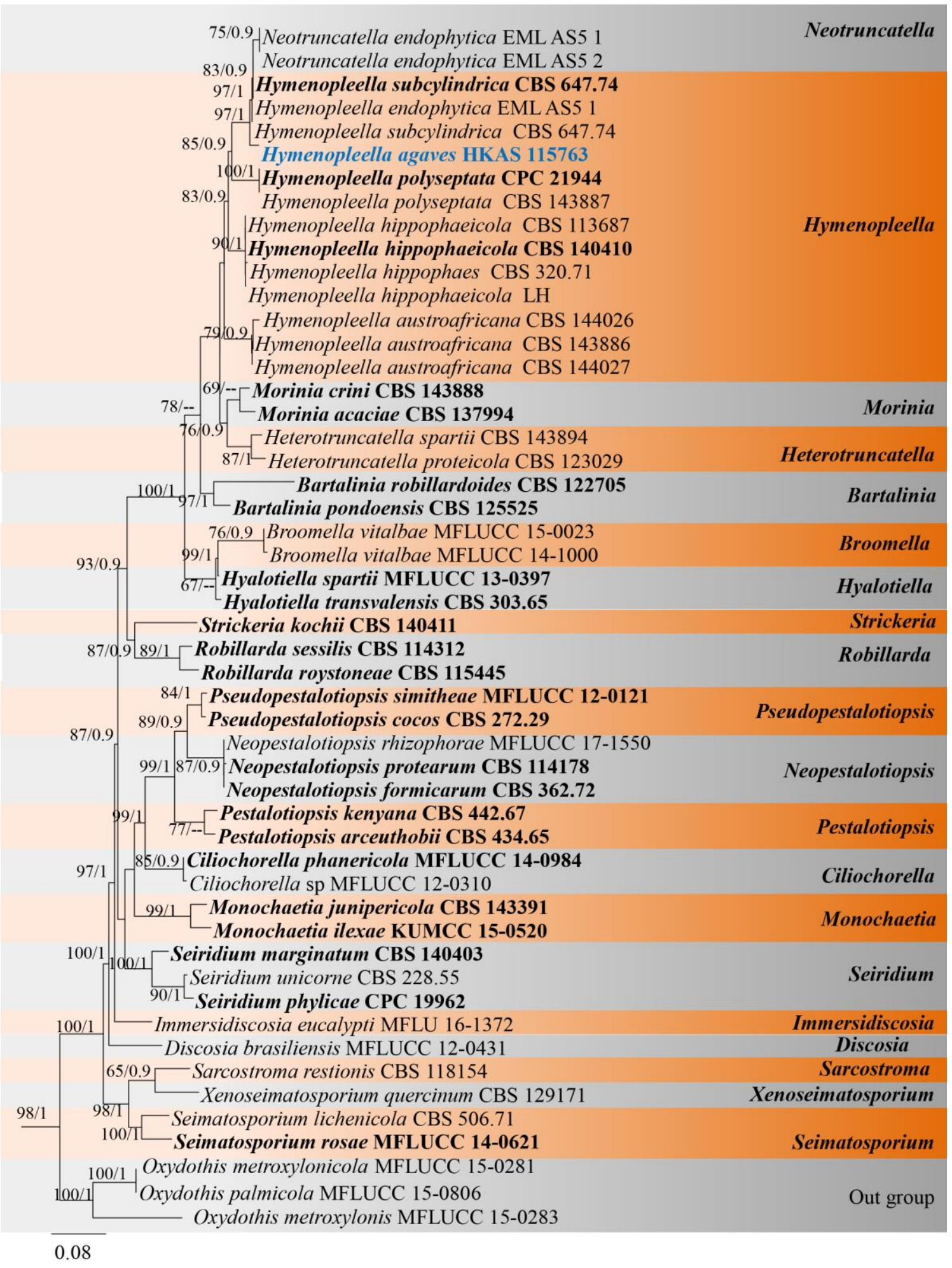

Figure 21 - Phylogram generated from maximum likelihood analysis based on combined LSU, ITS, rpb2 and tef- 1 sequence data. Fifty taxa were included in the combined analyses, which comprised 2589 characters $(\mathrm{LSU}=827 \mathrm{bp}$, ITS $=595 \mathrm{bp}, r p b 2=831 \mathrm{bp}$, tef- $1=325 \mathrm{bp}$ ) after alignment. The best scoring RAxML tree with a final likelihood value of -18369.985225 is presented. The matrix had 2589 distinct alignment patterns, with $23.25 \%$ of undetermined characters or gaps. Estimated base frequencies were as follows: $\mathrm{A}=0.236689, \mathrm{C}=0.252770, \mathrm{G}=$ 0.263138, $\mathrm{T}=0.247403$; substitution rates: $\mathrm{AC}=1.245390, \mathrm{AG}=4.554482, \mathrm{AT}=1.522786, \mathrm{CG}=$ $0.892535, \mathrm{CT}=7.529789, \mathrm{GT}=1.000000$; gamma distribution shape parameter $\alpha=0.183969$. Bootstrap support values for maximum likelihood (ML) equal to or greater than $50 \%$ and clade credibility values greater than 0.90 (the rounding of values to 2 decimal proportions) from Bayesian 
inference analysis are labelled at each node. Ex-type strains are in black bold, while the new isolate is indicated in blue bold. The tree is rooted to Oxydothis metroxylonis (MFLUCC 15-0281, MFLUCC 15-0283) and O. palmicola (MFLUCC 15-0806).

Notes - Synnemapestaloides shangrilaensis is introduced here as a new species. In the phylogenetic analyses, S. shangrilaensis well-separated from Syn. ericacearum with 100\% ML, 1.00 PP statistical support (Fig. 23), while $S$. shangrilaensis shares similar conidial features with $S$. ericacearum. However, our collection can be distinguished from $S$. ericacearum by having pyriform, 4-septate conidia, while $S$. ericacearum has fusiform-ellipsoid to fusiform-cylindrical or clavate, 3-septate conidia. Besides, base pair differences between $S$. shangrilaensis and $S$. ericacearum (ex-type, DAOMC 251621) revealed 25 bp (4\%) differences in ITS (625 bp in total) and 7 bp (0.8\%) differences in LSU (800 bp in total) (Tanney et al. 2018). Hence, based on both morphology and phylogeny, we introduce our collection as a new species of Synnemapestaloides.
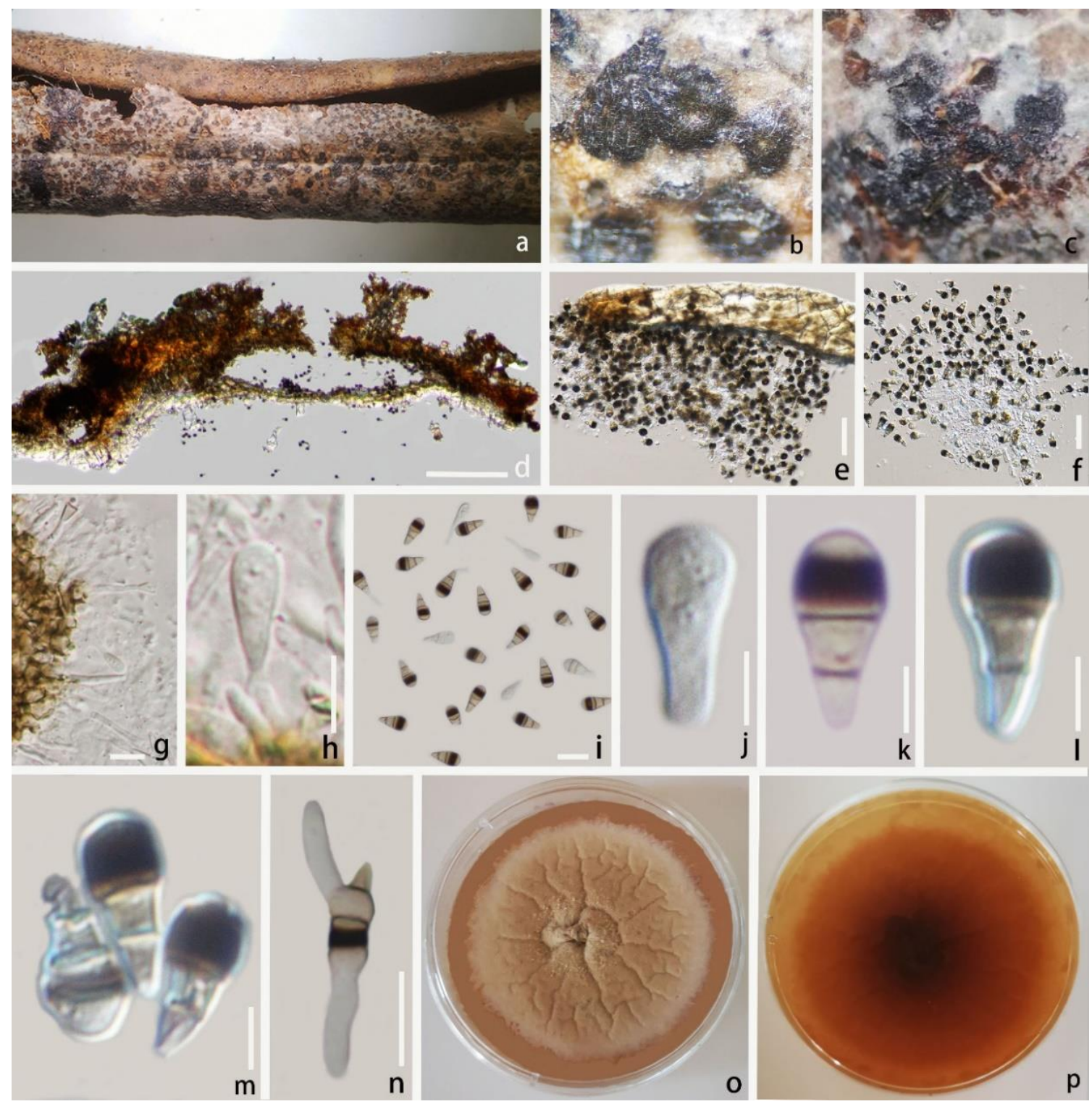

Figure 22 - Synnemapestaloides shangrilaensis (HKAS 113188, holotype). a, b Leaf spot. c Spot broken. d-f Section with intact host cuticle and conidia. g, h Conidiophores and conidiogenous cells. $\mathrm{i}-\mathrm{m}$ Morphology of conidia at different stages (young, mature, old). $\mathrm{n}$ Germinating conidium. $\mathrm{o}, \mathrm{p}$ Culture on MEA from surface and reverse. Scale bars: $\mathrm{d}=10 \mu \mathrm{m}, \mathrm{e}-\mathrm{h}=20 \mu \mathrm{m}, \mathrm{i}, \mathrm{n} 15 \mu \mathrm{m}$, $\mathrm{j}-\mathrm{m}=5 \mu \mathrm{m}$. 


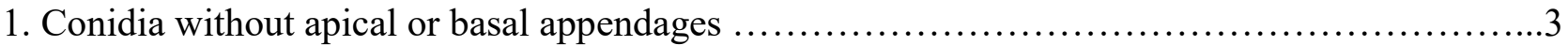

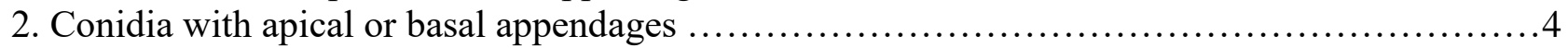

3. Pyriform conidia 4-septate

S. shangrilaensis

3. Fusiform-ellipsoid to fusiform-cylindrical or clavate conidia 3-septate S. ericacearum

4. 5-7-septate, lacking appendages, or with very short appendages S. juniper

4. Apical or basal appendages simple or branched S. rhododendri

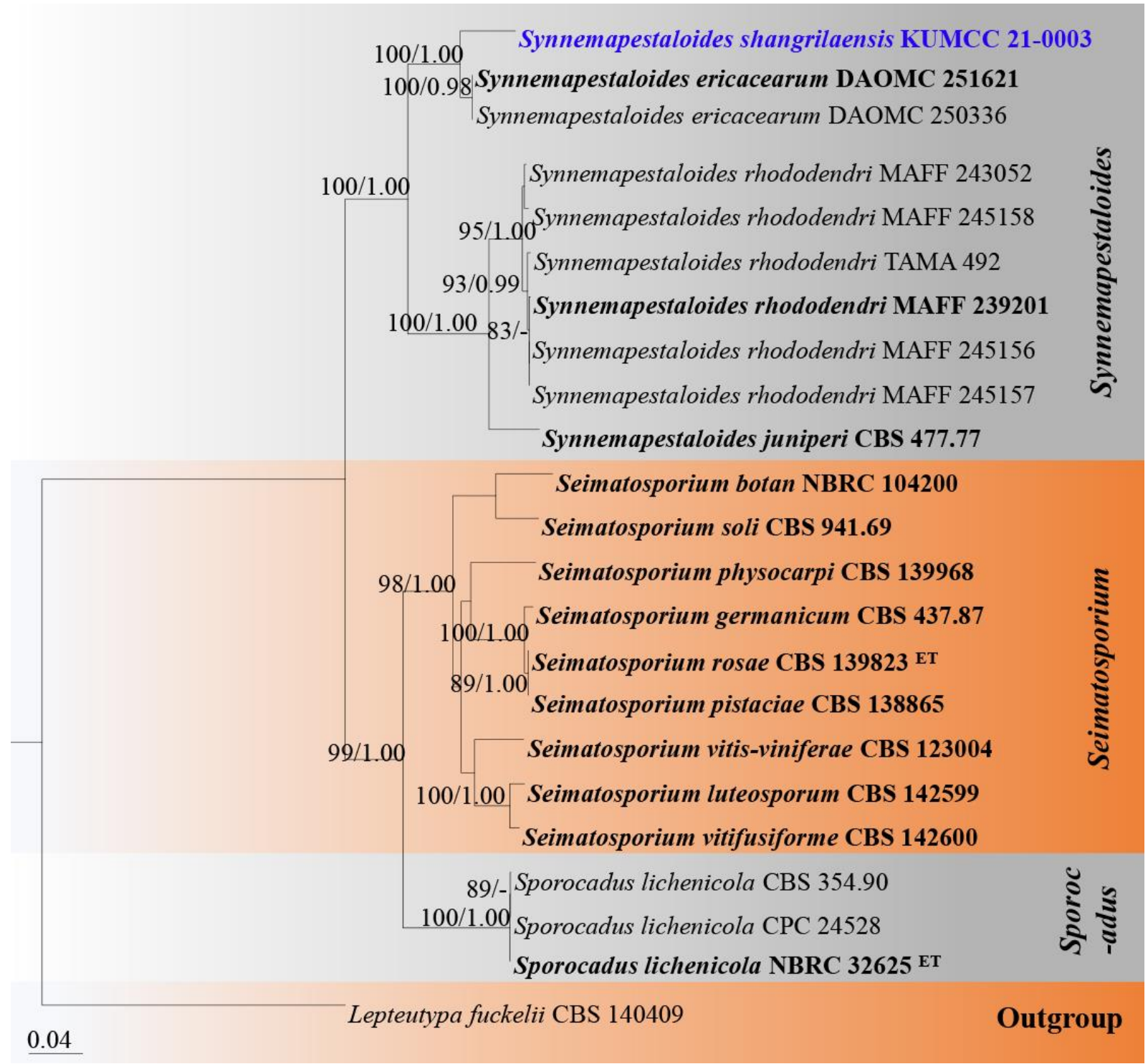

Figure 23 - Phylogram generated from maximum likelihood analysis based on combined LSU, ITS, rpb2, tub2 and tef-1 sequence data representing the species of Sporocadaceae. Related sequences are taken from Liu et al. (2019) and Tanney et al. (2018). 23 taxa were included in the combined analyses, which comprised 3557 characters (LSU $=1-790 \mathrm{bp}$, rpb2 $=791-1623 \mathrm{bp}$, tef- 1 $=1624-2216 \mathrm{bp}, t u b 2=2217-2995 \mathrm{bp}$, ITS $=2996-3558 \mathrm{bp})$ after alignment. A best scoring RAxML tree was established with a final ML optimization likelihood value of -14145.728580 . The matrix had 1082 distinct alignment patterns with $31.70 \%$ of undetermined characters or gaps. Estimated base frequencies were as follows: $\mathrm{A}=0.246921, \mathrm{C}=0.254224, \mathrm{G}=0.244720, \mathrm{~T}=$ 0.254135; substitution rates: $\mathrm{AC}=1.505895, \mathrm{AG}=3.954338, \mathrm{AT}=1.215412, \mathrm{CG}=1.084334, \mathrm{CT}$ $=6.895870$, GT $=1.000000$. Lepteutypa fuckelii CBS 140409 was used as the outgroup taxon. Numbers above branches are the bootstrap statistics percentages (left) and Bayesian posterior probabilities (right). Branches with bootstrap values $\geq 70 \%$ are shown at each branch and the bar 
represents 0.1 substitutions per nucleotide position. Hyphen (-) represents support values $\leq$ 70\%/0.95. Ex-type strains are in black bold, ex-epitype strains are superscript with ET, newly generated sequence is indicated in blue and bold for new taxa.

339. Dictyocephalos xinjiangensis R.L. Zhao, M.Q. He \& J.X. Li, sp. nov.

Fig. 24

Fungal names number: FN570854; Facesoffungi number: FoF 09907

Etymology - 'xinjiangensis' referring to the region where the holotype was collected.

Holotype - HMAS 55794

Gasterocarp consists of peridium, stem, and base, the whole basidiocarp reaching $206 \mathrm{~mm}$ long, $105 \mathrm{~mm}$ wide. Exoperidium depressed globose or oblong, $75 \mathrm{~mm}$ tall, $100 \mathrm{~mm}$ wide, less than $5 \mathrm{~mm}$ thick, pale yellow to yellowish-brown, covered with irregular dehiscence, thickness variable, dorsal rounded and obtuse, deeply sulcus septum wide, up to 10-20 $\mathrm{mm}$. Endoperidum whitish, cream white, membranaceous, fragile. Stem $110 \mathrm{~mm}$ long, pale yellow, $15-55 \mathrm{~mm}$ thick, solid, woody, thickly covered with irregular appressed scales, tapering toward the base, usually with a slightly curved base. Rhizomorph not observed. Gleba pulverulent, cream white to pale yellow in the early stage, and gradually turns to brownish-yellow from inside at maturity. Basidiospore globose to subglobose, 4.4-8.5 $\mu \mathrm{m}$ diameter, olive-green, hyaline, occasionally conical or oblong, with an oil drop in the center, occasionally two drops, surface ornamented with verrucous elements, verrucae less than $1 \mu \mathrm{m}$. Basidia-basidioles 7.3-11.3 $\times 4.7-7.3 \mu \mathrm{m}$ diameter, hyaline, globose or subglobose. Capillitium rarely present. Exoperidium composed of branched hyaline hyphae, $4.2-$ $10.2 \mu \mathrm{m}$ diameter, thin-wall, often constricted at the septa. Endoperidium composed of hyaline hyphae which 2-6.2 $\mu \mathrm{m}$ diameter, olive-green, curved, thin-wall, with oil droplets inside.

Habitat - in arid or semi-arid sand and sandy soil.

Distribution - China, Xinjiang Uygur Autonomous Region.

Material examined - China, Xinjiang Uygur Autonomous Region, 14 September 2015, ZhiLing Ling (HMAS55794, holotype). GenBank accession numbers (LSU) MZ047793 and (ITS) MZ047791.

Notes - Dictyocephalos is a distinct genus characterised by powdery cellular gleba with permanent cells, dehiscence by irregular breaking away of the peridium and persistent basidiabasidioles and globose, subglobose verrucose basidiospores (Long \& Plunkett 1940). This genus is monotypic with the type species D. attenuatus (Peck) Long \& Plunkett (Dios et al. 2002). In the phylogenetic tree, $D$. attenuates and $D$. xinjiangensis are sister taxa with a bootstrap value of 99 (Fig. 25). They are macroscopically quite different in several characteristics. First, the basidiocarps of D. xinjiangensis are larger (206 mm long, peridium $75 \mathrm{~mm}$ tall, $100 \mathrm{~mm}$ wide) than $D$. attenuates (Fan \& Liu 2004). Secondly, the stem of D. attenuates has a bulbous base (25 mm wide), while the stem of $D$. xinjiangensis tapers towards the base and is usually slightly curved. They also differ in the irregular breaking away of the peridium, D. attenuates is dorsiventrally flattened, breaking to 1-2 $\mu \mathrm{m}$, while in D. xinjiangensis it is 10-20 $\mu \mathrm{m}$ (Long \& Plunkett 1940). The species resemble each other in having similar basidiospores (Kreisel \& Al-Fatimi 2004). However, the basidiospores of $D$. xinjiangensis are sometimes conical, oblong and olive-green, while in $D$. attenuates they are yellowish-brown. Furthermore, they differ in 75 loci in the ITS sequences (Martín et al. 2000). Dictyocephalos attenuates and Phellorinia herculean also resemble Dictyocephalos xinjiangensis. However, the basidiocarps of $P$. herculean are less than $85 \mathrm{~mm}$ tall and $35 \mathrm{~mm}$ diameter. The exoperidium is continuous with stem and composed of branched hyaline hyphae with inflated globose elements at the apex (Yousaf et al. 2012).

340. Phellorinia longistriatica R.L. Zhao, M.Q. He \& J.X. Li, sp. nov. Fig. 26

Fungal names number: FN570855; Facesoffungi number: FoF 09908

Etymology - In reference to the stem with deeply striate-sulcate or thickly covered with large appressed scales.

Holotype - HMAS 255795 

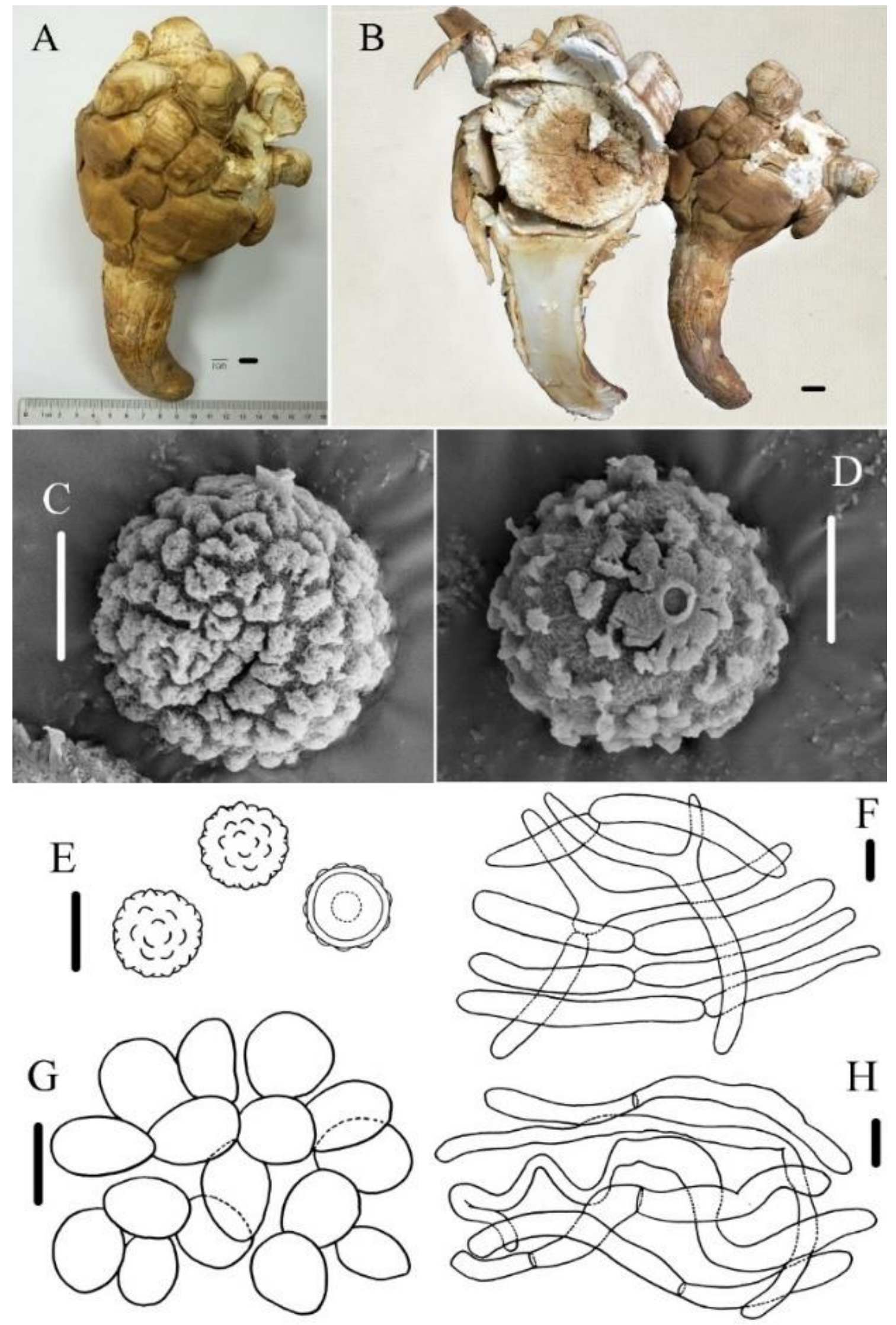

Figure 24 - Dictyocephalos xinjiangensis (HMAS255794, holotype). a, b Gasterocarps. $\mathrm{c}, \mathrm{d}$ Basidiospores under SEM. e Verrucose basidiospores. f Exoperidial hyphae. g Groups of globular elements. h Endoperidial hyphae. Scale bars: $\mathrm{a}-\mathrm{b}=1 \mathrm{~cm}, \mathrm{c}-\mathrm{d}=2 \mu \mathrm{m}, \mathrm{e}-\mathrm{g}=5 \mu \mathrm{m}$, $\mathrm{h}=2 \mu \mathrm{m}$. 
Basidiocarp is completely mature, cream white, $150 \mathrm{~mm}$ long and $60 \mathrm{~mm}$ wide. The apex is rounded to truncate. Exoperidium depressed globose or slightly subglobose, brown to blackishbrown, encrusted with sand or sandy soil. Covered with numerous angular, pyramidal warts, usually expanded at the base and broad at the more or less angular, 1-1.5 mm thick. Endoperidum whitish to cream white, membranaceous, fragile. Stem $110 \mathrm{~mm}$ long, maximum width up to 35mm, pale yellowish, thick, solid, woody, deeply striate-sulcate or covered with large appressed scales, tapered from apex to base and the base is clavate bulbous. Gleba rusty brown, brick red, compact, pulverulent or cotton floccose. Basidiospores globose to subglobose, finely verruculose, apedicellate, 5.6-6.8 $\mu \mathrm{m}$ diameter, brown to pale ochraceous. Capillitium rarely present, scant, hyaline, branched. Exoperidium composed branched hyaline hyphae with oil drops, 5-17.6 $\mu \mathrm{m}$ diameter, sometimes twisted, inflated at the apex. Endoperidium composed swollen hyaline hyphae, tapering toward the apex, 5-17.6 $\mu \mathrm{m}$ diameter, thin and smooth-walled, scarcely ramificate. Gleba consisting of groups of persistent basidia-basidioles, 14.6-24.8 $\mu \mathrm{m}$ diameter, hyaline, globose or subglobose, sometimes oblong.

Habitat - heavy encrusted in sandy soil, in arid or semi-arid regions.

Distribution - Inner Mongolia Autonomous Region, China.

Material examined - China, Alashan Right Banner, Inner Mongolia Autonomous Region, 26 July 2017, R.D. Liu, D.L. Liu and Z.L. Ling (HMAS 255795, holotype). GenBank accession numbers (LSU) MZ047794 and (ITS) MZ047792.

Notes - Phellorinia is a monotypic genus containing a single species, $P$. herculean (Pers.) Kreisel, that is widely distributed in dry and warm temperate regions (Yousaf et al. 2012). When compared with $P$. herculean, $P$. longistriatica can be distinguished by its longer stem $(110 \mathrm{~mm})$ with a bulbous base ( $35 \mathrm{~mm}$ diameter) which is deeply striate-sulcate. These species have similar basidiospores (Fan 2005). However, the exoperidium of $P$. herculean has branched, hyaline hyphae, with inflated globose elements at apex, whereas those of $P$. longistriatica have hyaline hyphae, which is usually swollen, tapering toward the apex, and scarcely ramificate. The endoperidium hyphae of $P$. longistriatica are also twisted and slightly inflated at the apex, occasionally. Furthermore, they differ in $15 \mathrm{bp}$ in the ITS sequences which also can easily separate them (Martín et al. 2000).

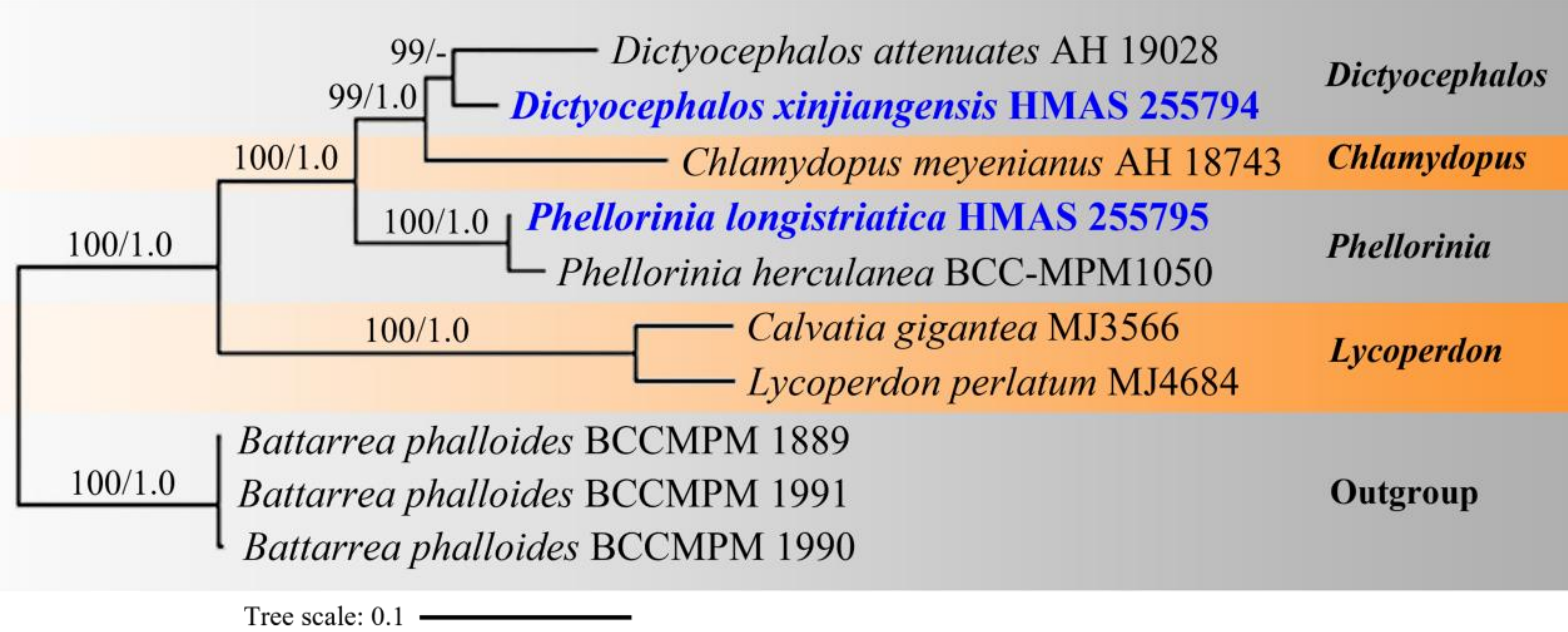

Figure 25 - Phylogram generated from maximum likelihood analysis based on ITS sequence data (including 711 base pair) representing the species of Dictyocephalos, Phellorinia and related taxa. Battarrea phalloides (BCCMPM 1889; BCCMPM 1990 and BCCMPM 1991) were used as the outgroup taxa. The newly generated sequences are indicated in blue. 

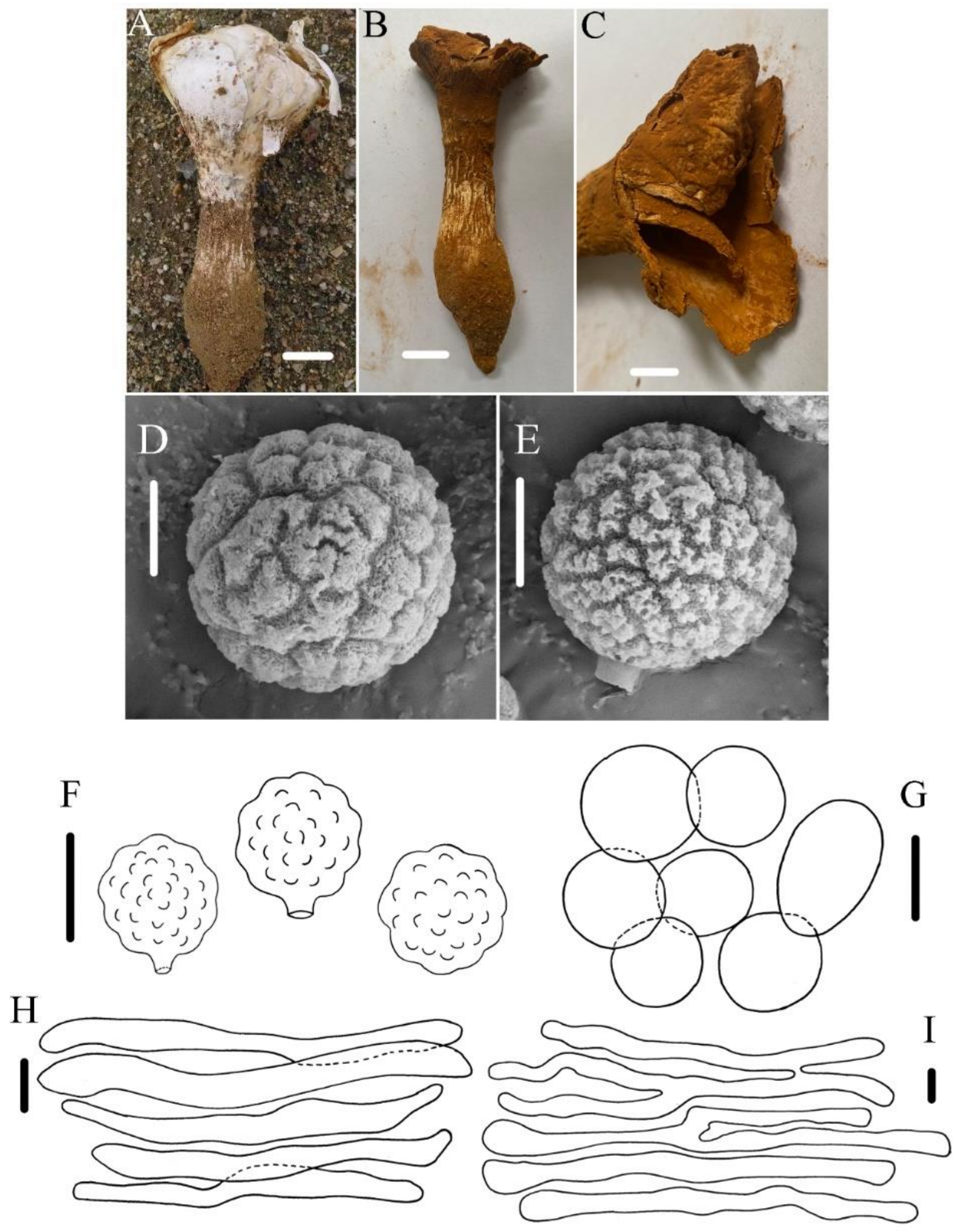

Figure 26 - Phellorinia longistriatica (HMAS 255795, holotype). a-c Gasterocarps. $\mathrm{d}$, e Basidiospores under SEM. f Verrucose basidiospores. g Groups of globular elements. h Exoperidial hyphae. i Endoperidial hyphae. Scale bars: $\mathrm{a}-\mathrm{c}=2 \mathrm{~cm}, \mathrm{~d}-\mathrm{e}=2 \mu \mathrm{m}, \mathrm{f}=5 \mu \mathrm{m} . \mathrm{g}=10$ $\mu \mathrm{m}, \mathrm{h}=3 \mu \mathrm{m}, \mathrm{i}=2 \mu \mathrm{m}$.

341. Cantharellus hongneungensis B. Buyck, R. Ryoo, V. Hofst. \& V. Antonín, sp. nov. Fig. 27 Index Fungorum number: MB 840233; Facesoffungi number: FoF 09912

Etymology - 'hongneungensis' named after the arboretum where it was found. 
Holotype - BRNM 825747, isotype PC0142453.
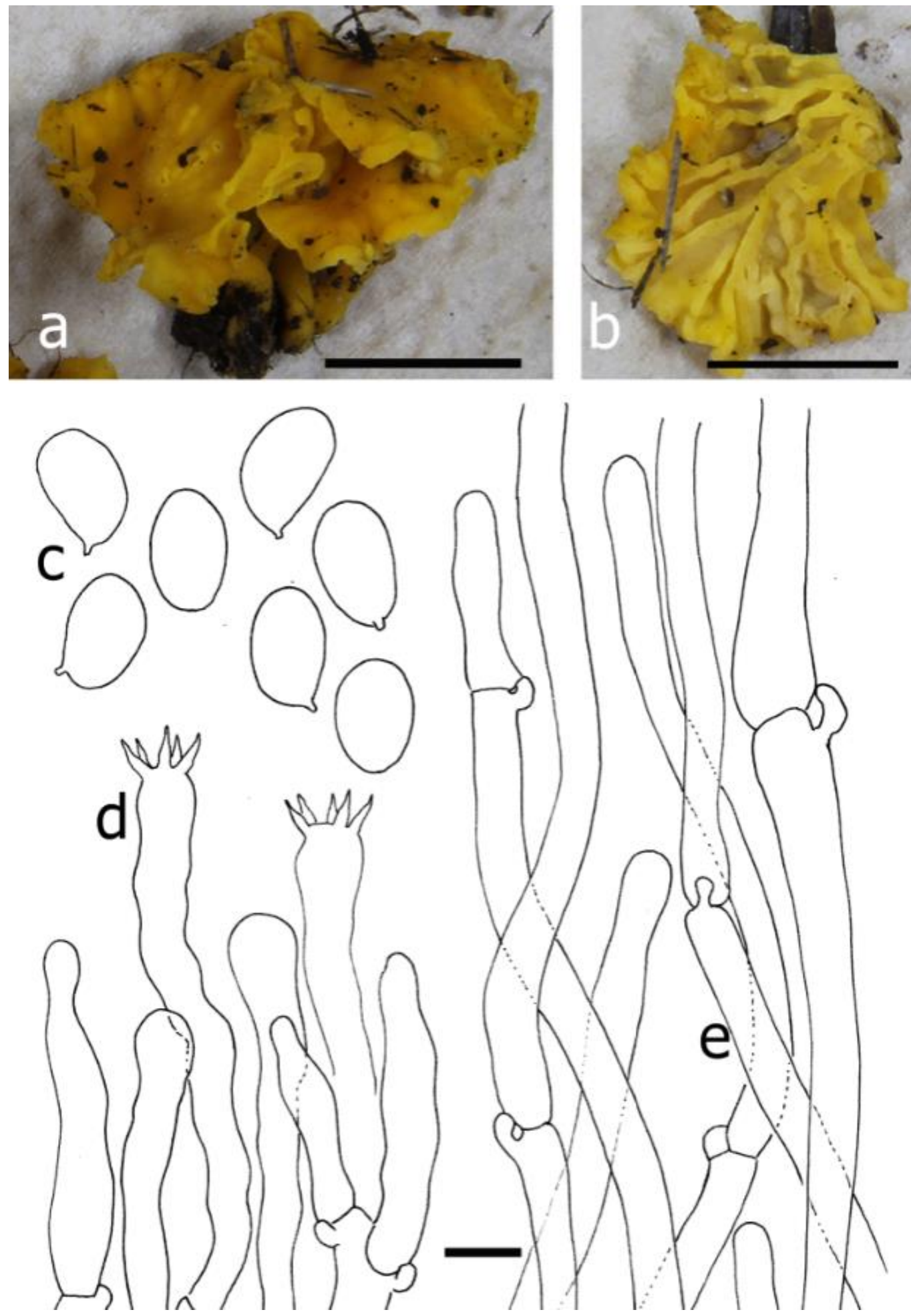

Figure 27 - Cantharellus hongneungensis (BRNM 825747, holotype). a-b Freshly collected fruiting bodies. c Spores. $d$ Basidia and basidiola. e Hyphal extremities of the pileipellis near midradius. Scale bars: $\mathrm{a}-\mathrm{b}=10 \mathrm{~mm}, \mathrm{c}=5 \mu \mathrm{m}, \mathrm{d}-\mathrm{e}=10 \mu \mathrm{m}$. Photo V. Antonín, drawings B. Buyck.

Basidiomata dispersed, single or in groups, some almost in fascicles. Pileus $10-20 \mathrm{~mm}$ broad, infundibuliform with depressed centre and involute margin, when old almost applanate or low convex with slightly depressed to almost plane centre, and distinctly undulate, hygrophanous, not translucently striate when moist, smooth, glabrous, watery yellow, becoming watery greyish yellow 
tinged when old. Hymenophore composed of distant $(\mathrm{L}=12-15,1=1-2)$, decurrent, very thick vein-like folds, irregularly branching, weakly intervenose when old, pale yellowish when young, later bright yellow, but paler than pileus. Stipe short, $8-22 \times 1-3(4) \mathrm{mm}$, cylindrical or slightly tapering towards base, seems to be slightly pubescent (?) when young, then smooth and glabrous, dirty yellow when moist, concolorous or mostly paler than pileus. Context thin, concolorous with pileus, fibrillose-solid, hollowing in stipe; smell aromatic, sweetish. Spore print not obtained. Spores ellipsoid, (6.7)7.4-7.92-8.4(8.8) $\times(4.4) 4.9-5.19-5.5(5.6) \mu \mathrm{m}, \mathrm{Q}=(1.38) 1.41-1.53$ $-1.65(1.90)$, smooth, with a small apiculus. Basidia rather long, 70-85 $\times 8-10 \mu \mathrm{m}$, irregular-wavy in outline, clavulate, (2-)5-6-spored; basidiola mostly tapering upwards when young, later subcylindrical with apical swelling. Cystidia not observed. Subhymenium composed of large, voluminous cells, wider than basidia, but not really forming a pseudoparenchyma. Pileipellis a cutis of horizontally oriented, sparsely septate, mostly 5-12 $\mu \mathrm{m}$ wide, thin-walled hyphae running across each other in various directions and with few visible hyphal terminations; terminal cells mostly 25$100 \mu \mathrm{m}$ long, cylindrical, obtuse-rounded at the tips, sometimes with a very weak subapical constriction or slightly narrowing apically. Clamp connections everywhere and very distinct.

Material examined - Korea, Seoul, Hongneung Arboretum, alt. c. 130 m, 37 $35^{\prime} 40^{\prime \prime} \mathrm{N}$, 127 02'44"E, 5 August 2013, leg. V. Antonín and R. Ryoo, VA 13.120 (BRNM 825747 holotype, isotype PC0142453). GenBank accession numbers: rpb2 (MW286820).

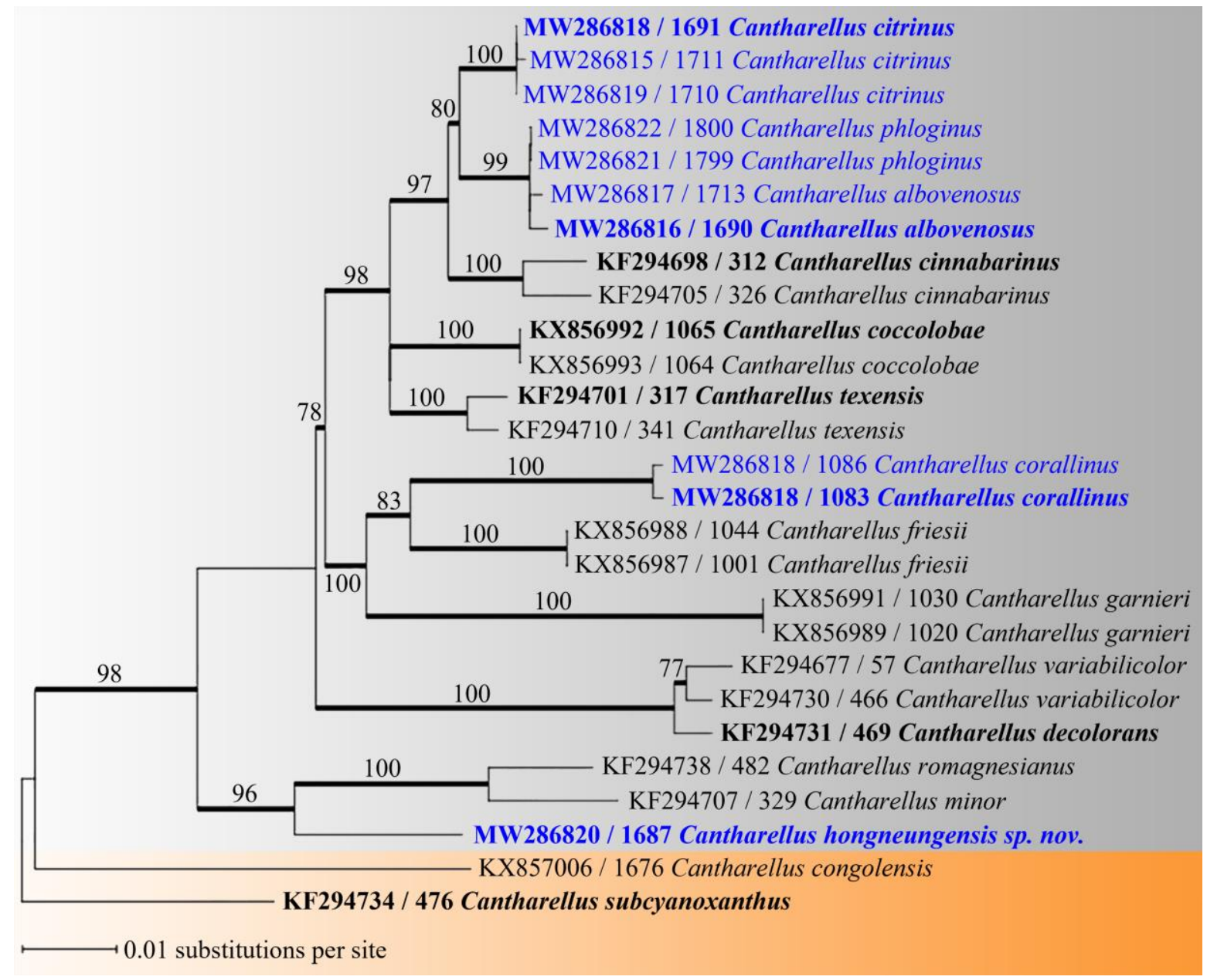

Figure 28 - Most likely phylogram $(-\ln =3279.62707)$ inferred from analyses of 27 sequences of the rpb2 gene, region 5-7. The aligned dataset for small, yellowish-orange to red Cantharellus having clamp connections (subgenera Cinnabarini and Pseudocantharellus) comprised 960 characters. Taxon names are preceded by GenBank accession numbers and their extraction nr. Cantharellus subcyanoxanthus (KF294734) and C. congolensis (KX857006) were used as outgroup taxa following Buyck et al. (2014). The newly generated sequence for $C$. hongneungensis sp. nov. 
is indicated in blue and bold; ex-type sequences in black bold font; other Cantharellus for which $r p b 2$ sequences were newly produced are simply in blue font, not in bold. Significantly supported branches, that received bootstrap values equal or greater than $70 \%$, are in bold and bootstrap percentages indicated along the branches.

Notes - Notwithstanding the morphological resemblance with a Korean species of subgenus Cinnabarini, viz. C. citrinus Buyck, R. Ryoo \& Antonín, because of its equally small size and possession of thick veins under the pileus (Buyck et al. 2020a), C. hongneungensis is unrelated to it (Fig. 28). Our new species belongs in Cantharellus subg. Parvocantharellus, a subgenus still interpreted as 'sensu lato' (see Buyck et al. 2020b) and with both tropical and temperate species. In Asia, this subgenus harbours also the Korean C. koreanus, and Indian Cantharellus sikkimensis, which are both part of a group of yellowish-brown, much slenderer chanterelles of the $C$. appalachiensis, $C$. tabernensis species complex (Antonín et al. 2017), and also the Asian $C$. curvatus belongs here. It has a very similar microscopy but differs in the slightly larger size of basidiomata, but especially in the completely different hymenophore composed of densely arranged gill-like folds that are strongly interveined (Buyck et al. 2020a). The new species, $C$. hongneungensis, is most similar in overall habit and size to the European $C$. romagnesianus which has much larger spores. Our new species differs from all other known small species in subgenera Cinnabarini and Parvocantharellus in the thick, bright yellow veins constituting the hymenophore. Model parameters for the most likely tree were as follows: proportion of invariable sites $=0.494$; gamma shape parameter $=2.073$; nucleotides frequencies: $\mathrm{A}=0.25364, \mathrm{C}=0.24861, \mathrm{G}=0.25717$, $\mathrm{T}=0.24068$; substitution rates $\mathrm{A}-\mathrm{C}=0.88913, \mathrm{~A}-\mathrm{G}=5.99318, \mathrm{~A}-\mathrm{T}=0.56607, \mathrm{C}-\mathrm{G}=0.99001$, $\mathrm{C}-\mathrm{T}=13.24628, \mathrm{G}-\mathrm{T}=1.00000$. Branch robustness was evaluated based on 500 bootstrap replicates (BS) using the same settings as for the searches for the most likely tree. (Fig. 28).

342. Cronartium armandii X. Qi, P. Zhao \& L. Cai, sp. nov.

Fig. 29

Index Fungorum number: IF558588; Facesoffungi number: FoF 09996

Etymology - 'armandii' reflects the host species on which it was collected.

Holotype - HMAS45350

Spermogonia not found. Aecia peridermioid, intracortical in origin, becoming erumpent; aeciospores borne singly, ellipsoid, obovoid, or subglobose, 10-13 ×6-11 $\mu \mathrm{m}$, wall hyaline, about 2-3 $\mu \mathrm{m}$ thick including verrucae connected by filaments, verrucae $1.4-2.5 \mu \mathrm{m}$ high, densely verrucose, nail head-like verrucae with 7-8 layers, with obviously smooth area on surface, contents yellow. Uredinia usually lacking, urediniospores occasionally accompanying the telia, echinulate, sometimes with smooth surface at apex. Telia hypophyllous, hair-like columns, 0.4-1 $\mu \mathrm{m}$ long, straight or slight curved, bright yellow; teliospores oblong, 35-61 $\times 9-18 \mu \mathrm{m}$, catenulate, wall yellowish-brown, $0.4-0.9 \mu \mathrm{m}$ thick, without surface ornamentations.

Distribution - China, Gansu, Henan, Shanxi and Tibet.

Material examined - China, Henan, Lushi, aecial stage on Pinus armandii, May 1982, X.S. Li. (HMAS 45350, holotype); China. Shaanxi, Ningshan, 0, I on Pinus armandii, April 1966, J. Yao (HMAS 56424); China, Gansu, Zhugqu, telial stage on Ribes maximowiczii, September 1992, J.Y. Zhuang (HMAS 79166). China, Tibet, Jilong, telial stage on Ribes orientale, September 1990, J.Y. Zhuang (HMAS 64281). GenBank accession numbers HMAS 45350 (ITS) MZ520620 and (LSU) MZ520623, HMAS 79166 (ITS) MZ520620 and (LSU) MZ520623, HMAS 64281(LSU) MZ520623.

Notes - The rusts on Pinus armandii in China were usually identified as Cronartium ribicola or C. quercuum based on morphology or telial hosts (Tai 1979, Cao \& Li 1999, Cao et al. 2000, Chen 2002, Zhuang 2005). However, our phylogenetic analyses showed that above blister rusts on $P$. armendii and two Ribes species ( $R$. maximowiczi and $R$. orientale) are conspecific but phylogenetically distant from $C$. ribicola and $C$. quercuum (Fig. 30). The aeciospores of Cronartium armandii are relatively smaller than that of $C$. ribicola $(10-13 \times 6-11 \mu \mathrm{m}$ vs $11-29 \times$ 15-20 $\mu \mathrm{m})$. Besides, compared with $C$. ribicola, the verrucae on the aeciospores of Cronartium 
armandii possess more layers (7-8 vs 3-6). Cronartium armandii also differs from $C$. quercuum in its relatively slender teliospores and straight telia. In addition, this rust fungus has its telial stage on Ribes spp. (Grossulariaceae), while C. quercuum is on Quercus spp. (Fagaceae). We revealed the life cycle of this novel species with its aecial stage on $P$. armandii and telial stage on two Ribes species (Grossulariaceae).
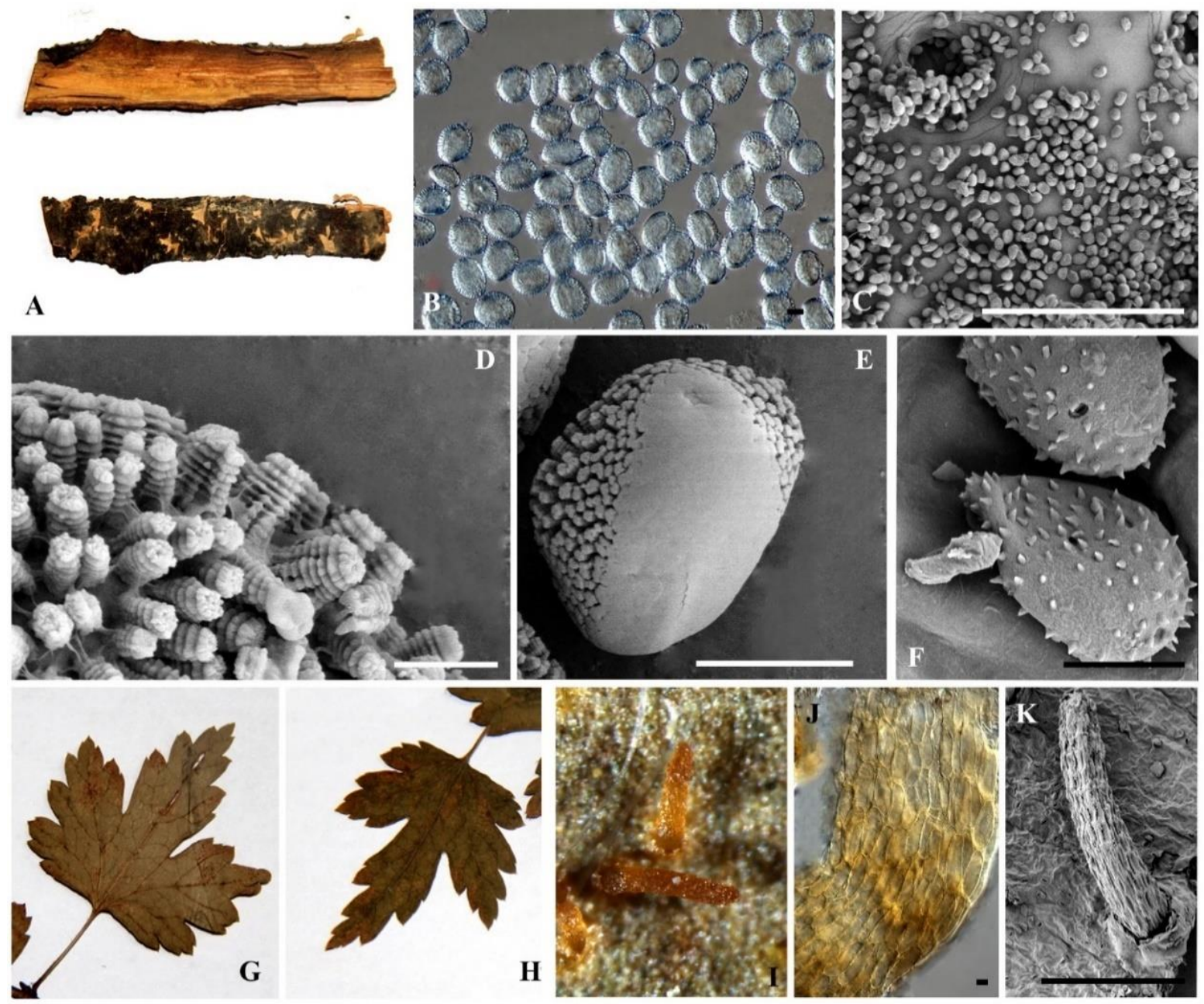

Figure 29 - Cronartium armandii on $P$. armandii (HMAS45350, holotype) and $R$. maximowiczii (HMAS79166). a Aecia on stem of $P$. armandii. b Globoid or ellipsoid aeciospores observed by LM. c SEM of aeciospores on the stem surface. d Aeciospores with nail head-like verrucae with multiple layers observed by SEM. e Aeciospores with smooth area observed by SEM. f Urediniospores with echinulate spines observed by SEM. g Hypophyllous telia on $R$. maximowiczii. h No telia on the upper leaf surface of $R$. maximowiczii. i Hair-like telia on the surface of $R$. maximowiczii. j Section of a telium observed by LM. k Telium observed by SEM. Scale bars: $b, e, f, j=10 \mu \mathrm{m}, \mathrm{c}=300 \mu \mathrm{m}, \mathrm{d}=2.5 \mu \mathrm{m}, \mathrm{k}=100 \mu \mathrm{m}$.

343. Mucor phayaoensis V.G. Hurdeal, E. Gentekaki \& K.D. Hyde, sp. nov.

Index Fungorum number: IF558522; Facesoffungi number: FoF 09892

Fig. 31

Etymology - 'phayaoensis' named after the province from where the fungus was isolated.

Holotype - MFLU 21-0080

Saprobic in soil. Asexual morph: Columellae 10-26.5 $\times 8-25.5 \mu \mathrm{m}(\overline{\mathrm{x}}=14 \times 16.5 \mu \mathrm{m}, \mathrm{n}=$ 30 ), mostly globose, sometimes broad ovate, hyaline to pale brown, short collarette. Sporangia 13.5-51.5 $\times 14.5-62 \mu \mathrm{m}(\overline{\mathrm{x}}=19 \times 26 \mu \mathrm{m}, \mathrm{n}=24)$, globose, deliquescent, brown to pale yellow. Sporangiospores $5-10 \times 2.5-5 \mu \mathrm{m}(\overline{\mathrm{x}}=7 \times 4 \mu \mathrm{m}, \mathrm{n}=40)$, ellipsoidal, sometimes flattened on one 
side, abundant, smooth-walled. Chlamydospores largely variable in size and shape. Zygospores not observed. Sporangiophore erect, mostly single and sympodial branching, hyaline, $2.5-9.5 \mu \mathrm{m}(\overline{\mathrm{x}}=$ $4.5 \mu \mathrm{m}, \mathrm{n}=30$ ) wide. Sexual morph: Not observed.

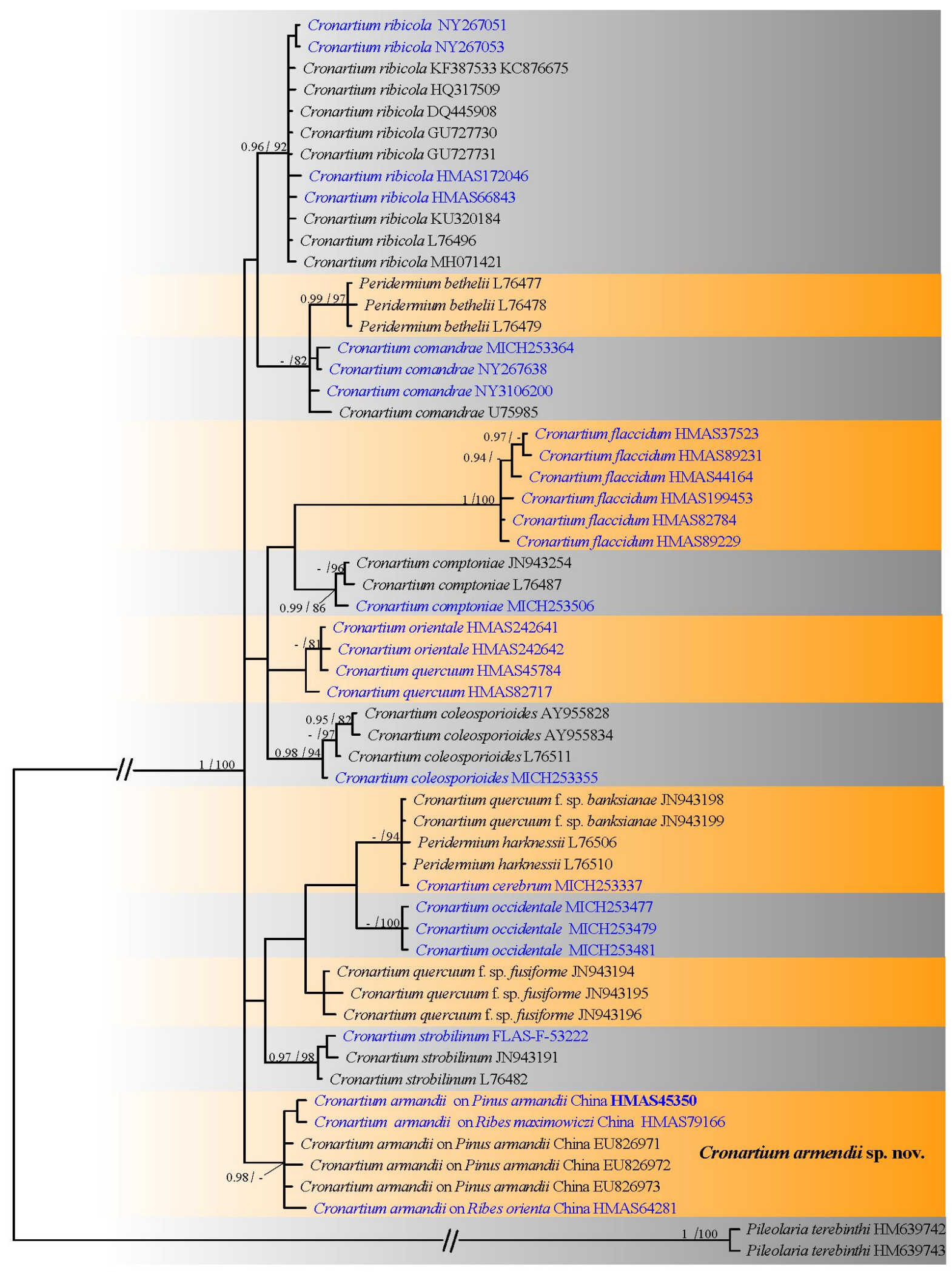

Figure 30 - Phylogenetic tree derived from Bayesian Markov chain Monte Carlo (MCMC) analyses of concatenated data of rDNA ITS and LSU sequence data. Two specimens of Pileolaria 
terebinthi was used as outgroup taxa. Values on the branches indicate maximum likelihood bootstrap values and Bayesian posterior probabilities. Hyphen (-) indicates that bootstrap values were less than $70 \%$ and Bayesian posterior probabilities less than 0.90 . The bar represents 0.1 substitutions per nucleotide position. Holotype specimen is in black bold, newly generated sequence is indicated in blue and bold for new taxa.

Culture characteristics - Colonies on MEA have faster growth compared to PDA. Day-old cultures are white changing to pale grey or pale yellow, cottony as growth progresses. Colour change beginning from the point of inoculation and progressing outwards. In MEA, the colony reaches a diameter of $51 \mathrm{~mm}$ within two days at $25^{\circ} \mathrm{C}$. Colony covers the plates $(90 \mathrm{~mm})$ within the third or fourth day after inoculation, but does not touch the lids. The reverse of the colony is white to pale yellow. The colony is circular in shape, entire and flat or slightly raised. Growth is observed at $8,20,25$ and $30^{\circ} \mathrm{C}$. Sporulation is observed at temperatures 20,25 and $30^{\circ} \mathrm{C}$.

Material examined - Thailand, Phayao Province, on soil, 18 December 2019, Vedprakash Godadhar Hurdeal, (MFLU 21-0080, holotype), ex-type living culture, MFLUCC 21-0044, collected and isolated by Vedprakash Godadhar Hurdeal, (MFLU 21-0081), living culture, MFLUCC 21-0043. GenBank accession numbers MFLU 21-0080 (ITS) MZ379498 and (LSU) MZ379501, MFLU 21-0081 (ITS) MZ379499 and (LSU) MZ379502.

Notes - Blast search using ITS of M. phayaoensis strains as queries indicated that the top hits were sequences designated as M. fragilis (isolates V9D and LS266, 98.65 and 98.49\% identity, 97 and $100 \%$ query cover, respectively). When using LSU of $M$. phayaoensis as query, the top hit was M. racemosus (ATCC1216B, 100\%; query cover: 100\%). Evidence obtained from phylogeny (ITS/LSU) and morphological data, suggested that $M$. phayaoensis differed from known species of Mucor. In both maximum likelihood and Bayesian inference analyses, $M$. phayaoensis grouped as sister to M. variicolumellatus within the M. circinelloides complex (Fig. 33). In the preliminary phylogenetic analysis including all strains of the $M$. circinelloides complex, several sequences designated as $M$. fragilis (including V9D and LS266) claded with other known and officially described species. Further information about $M$. fragilis and the $M$. circinelloides complex in general is provided in Wagner et al. 2020. Strain CBS 236.35 is now the type of $M$. variicolumellatus, and isolates LS266, and V9D group with this species. In contrast to $M$. variicolumellatus, $M$. phayaoensis produces smaller columellae $(10-26.5 \times 8-25.5 \mu \mathrm{m})$ (mostly globose) and sporangia $(13.5-51.5 \times 14.5-62 \mu \mathrm{m})$, slightly bigger sporangiospores $(5-10 \times 2.5-5$ $\mu \mathrm{m})$, and narrower sporangiophores. However, the two taxa are similar in that they produce obovoid, ovate, and strawberry-shaped columellae. This feature is absent in M. lusitanicus, which branches off the M. phayaoensis and $M$. variicolumellatus clade. The colony formed by $M$. phayaoensis is primarily pale yellow compared to $M$. variicolumellatus, which is pale grey (De Souza et al. 2020, Wagner et al. 2020). The nucleotide difference of the trimmed ITS

344. Mucor takensis V.G. Hurdeal, E. Gentekaki \& K.D. Hyde, sp. nov.

Fig. 32

Index Fungorum number: IF558521; Facesoffungi number: FoF 09891

Etymology - 'takensis' named after the province from where the fungus was isolated.

Holotype - MFLU 21-0082

Saprobic in soil. Asexual morph: (Cultures grown in MEA at $25^{\circ} \mathrm{C}$ ): Columellae $7.5-38.5 \times$ 11-45 $\mu \mathrm{m}(\overline{\mathrm{x}}=22 \times 25 \mu \mathrm{m}, \mathrm{n}=30)$, globose to subglobose, hyaline to pale brown, with short collar. Sporangia 12.5-46 $\times 13.5-47 \mu \mathrm{m}(\overline{\mathrm{x}}=27 \times 25 \mu \mathrm{m}, \mathrm{n}=20)$, globose, pale brown to brown, smooth-walled, and persistent. Sporangiospores 3-5 $32-3 \mu \mathrm{m}(\overline{\mathrm{x}}=4 \times 2.5 \mu \mathrm{m}, \mathrm{n}=32)$, mostly ellipsoidal, occasionally globose, hyaline to pale yellow, abundant, smooth-walled. Zygospores and chlamydospores not observed. Sporangiophore erect, variable in length, sympodial and monopodial branches, aseptate, hyaline, $1.5-8 \mu \mathrm{m}(\overline{\mathrm{x}}=4.5 \mu \mathrm{m}, \mathrm{n}=30)$ wide. Sexual morph: Not observed.

Culture characteristics - Day-old cultures in both PDA and MEA are white with erect sporangiophores and wet, dark brown sporangia. Upon maturity, the colony remains mostly white to pale yellow with grey to brown sporangia in both culture media. Reverse is white to pale yellow. 
The colony is irregular, raised with undulate margin. Colony growth is faster in MEA than in PDA. At $25^{\circ} \mathrm{C}$, culture on MEA reaching a diameter of $54 \mathrm{~mm}(90 \mathrm{~mm}$ Petri dish) at second day postinoculation and covering the whole plate by the fourth day. The fungus has good sporulation at 20 , 25 and $30^{\circ} \mathrm{C}$. At 8 and $37^{\circ} \mathrm{C}$, growth is slow with no sporulation.

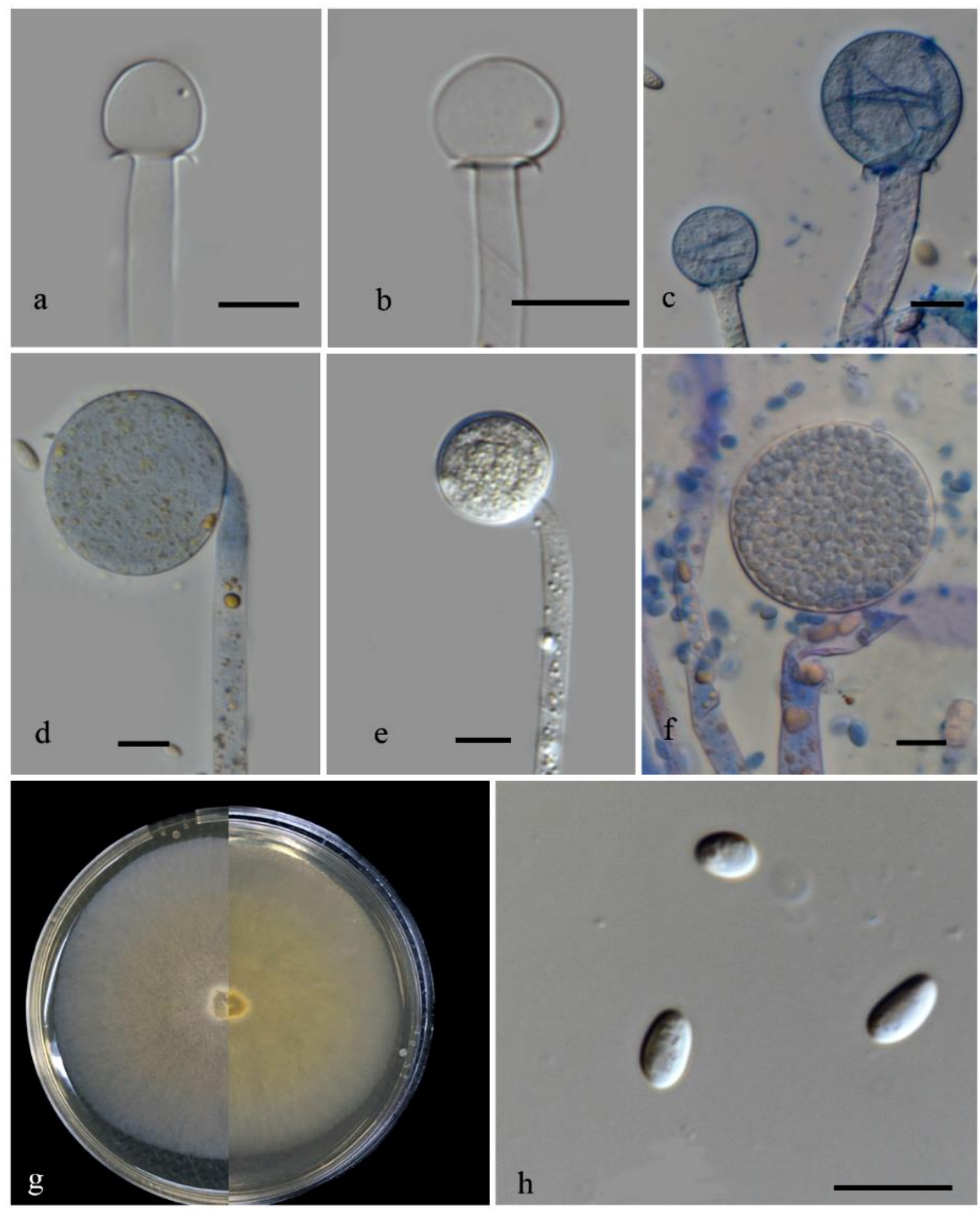

Figure 31 - Mucor phayaoensis (MFLU 21-0080, holotype). a-c Varying shape and size of columella and collarette. d-f Developing sporangium. g Culture on MEA from surface and reverse. $\mathrm{h}$ Sporangiospores. Scale bars: $\mathrm{a}-\mathrm{f}, \mathrm{h}=10 \mu \mathrm{m}$.

Material examined - Thailand, Tak Province, Thasong Yang, Mae Wa Luang, in soil, 24 October 2019, collected by Oundhyala Devi Padaruth and isolated by Vedprakash Godadhar Hurdeal, (MFLU 21-0082, holotype), ex-type living culture, MFLUCC 21-0041. GenBank accession numbers (ITS) MZ379497 and (LSU) MZ379500. 
Notes - The blast search against the GenBank database indicated the strain MFLU21-0082 belonged to Mucor. The top hits of the ITS and LSU sequences were M. irregularis: ITS, isolate C3B (similarity: 98.65\%; query cover:100\%), and LSU, strain CBS 103.93 (similarity: 99.50\%; query cover: 98\%). Using phylogeny, and morphophysiological data, M. takensis differs from the known species of the genus. In both maximum likelihood and Bayesian inference analyses, $M$. takensis grouped sister to the clade formed by M. irregularis strains (Fig. 33). Mucor takensis differs from $M$. irregularis in having globose to subglobose columellae, and sometimes slightly ellipsoidal with small collars, smaller sporangia, sporangiospores, narrower and aseptate sporangiophores. Mucor souzae, which branches off the clade formed by M. takensis and M. irregularis has septate sporangiophores with one or two septa, a feature which is absent in $M$. takensis (Crous et al. 2018, Lima et al. 2018). In contrast to M. souzae and M. irregularis, the sporangiospores are smaller in M. takensis $(3-5 \times 2-3 \mu \mathrm{m})$ and mostly ellipsoidal. Mucor souzae has faster growth in MEA $(90 \mathrm{~mm})$ than $M$. takensis $(70 \mathrm{~mm})$ at day 3 post inoculation. The nucleotide difference of the trimmed ITS sequences of M. takensis and M. irregularis (575 bp) ranged from $4.6-6.1 \%$.

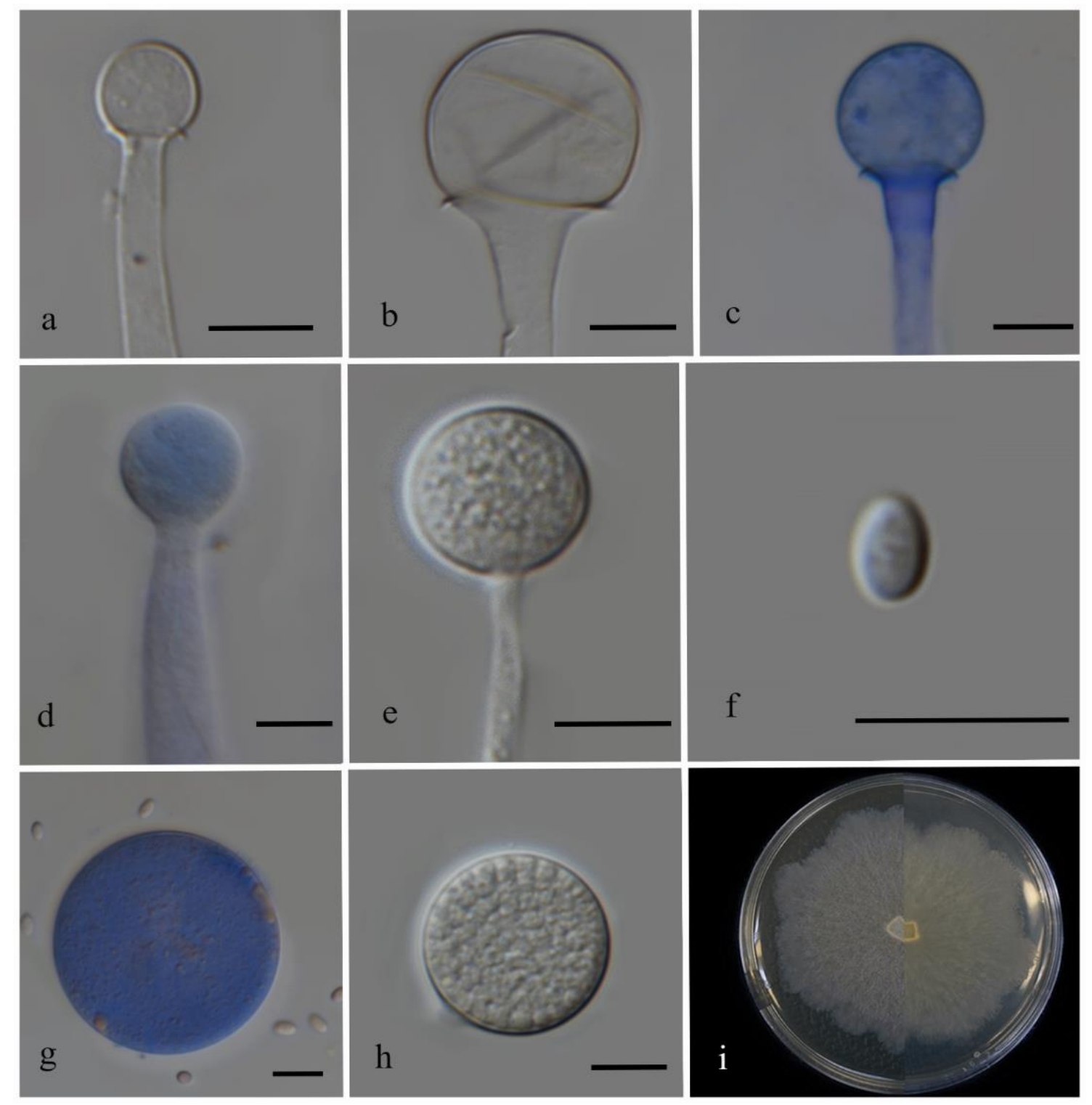

Figure 32 - Mucor takensis (MFLU21-0082, holotype). a-c Columella with collarette. $\mathrm{d}$, e, g, h Developing sporangium. f Sporangiospore. i Culture on MEA from surface and reverse. Scale bars: $\mathrm{a}-\mathrm{h}=10 \mu \mathrm{m}$. 


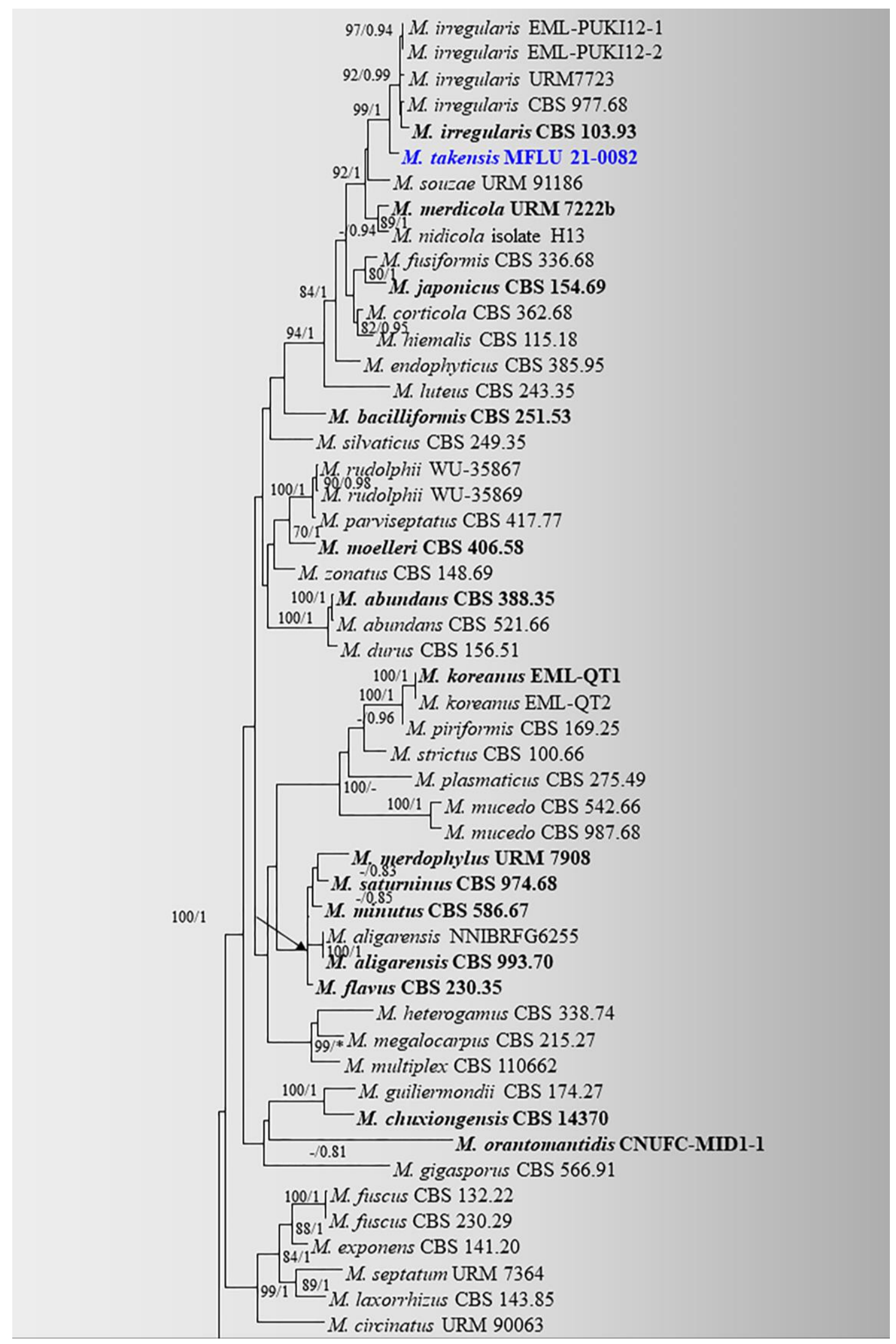

Figure 33 - Phylogenetic tree inferred from combined ITS, and LSU sequence data from105 taxa and 1232 sites (ITS: 1-539, LSU: 540-1232). The matrix had 700 distinct alignment patterns with $10.79 \%$ undetermined characters or gaps. Backusella dispersa CBS 195.28 and B. grandis CBS 186.87 were used as outgroup taxa. Maximum likelihood and Bayesian inference analyses were run. The final ML optimization likelihood value of the best scoring RAxML tree was 17746.091309. Numbers above branches indicate bootstrap percentages (left) and Bayesian 
posterior probabilities (right). Only bootstrap values $\geq 70 \%$ and posterior probabilities $\geq 0.7$ are shown. Scale bar indicates branch length in terms of number of substitutions per site._Hyphen (-) represents support values lower than the ones mentioned above. Ex-type strains are in black bold font. New taxa are in blue bold font.

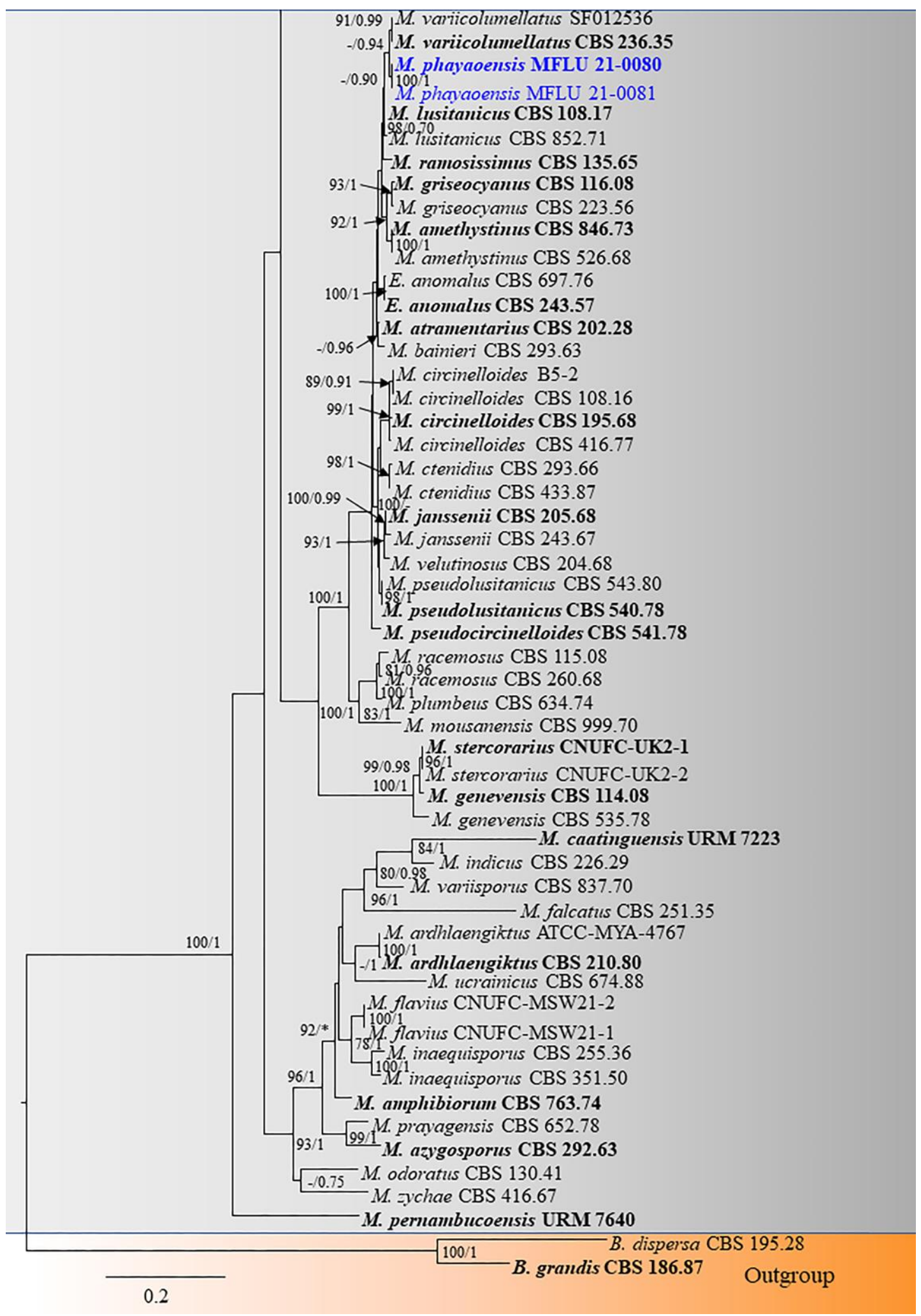

Figure 33 - Continued. 
Table 1 Comparisons of sexual species of Halobyssothecium

\begin{tabular}{|c|c|c|c|c|c|c|}
\hline \multirow{2}{*}{ Taxa } & \multirow{2}{*}{$\begin{array}{l}\text { Ascomata } \\
\text { size }(\mu \mathrm{m})\end{array}$} & \multirow{2}{*}{$\begin{array}{l}\text { Asci } \\
\text { size }(\mu \mathrm{m})\end{array}$} & \multicolumn{4}{|c|}{ Ascospores } \\
\hline & & & size $(\mu \mathrm{m})$ & Septa & Sheath & Colour \\
\hline H. carbonneanum ${ }^{\mathrm{a}}$ & $290-340 \times 380-420$ & $100-110 \times 13.5-16$ & $\begin{array}{l}(14.5-) 17-19.5(-22) \times \\
(5.5-) 6-7(-8)\end{array}$ & 1-septate & Lacking sheath & Yellowish-brown \\
\hline H. cangshanense ${ }^{\mathrm{b}}$ & $210-310 \times 220-320$ & $65-78 \times 11-13$ & $16.5-17.5 \times 6-7$ & 1-septate & Lacking sheath & $\begin{array}{l}\text { Subhyaline when young } \\
\text { and pale brown to brown } \\
\text { when mature }\end{array}$ \\
\hline H. estuariae ${ }^{\mathrm{c}}$ & $260-420 \times 260-350$ & $120-235 \times 10-25$ & $20-44 \times 4-9$ & 3-septate & Lacking sheath & $\begin{array}{l}\text { Central cells that are pale } \\
\text { brown to dark brown, } \\
\text { hyaline end cells }\end{array}$ \\
\hline H. obiones ${ }^{\mathrm{d}}$ & $360-400 \times 340-380$ & $180-214 \times 12-16$ & $28-47 \times 10-18$ & 3-septate & Lacking sheath & $\begin{array}{l}\text { End cells hyaline, central } \\
\text { cells brown }\end{array}$ \\
\hline H. thailandica ${ }^{\mathrm{e}}$ & $340-490 \times 215-345$ & $138-160 \times 17-21$ & $39-47 \times 8-10$ & 4-7-septate & $\begin{array}{l}\text { Surrounded by a } \\
\text { gelatinous sheath }\end{array}$ & Light brown to dark brown \\
\hline H. voraginesporum ${ }^{\mathrm{f}}$ & 125-215 diameter & $38-50 \times 8-10$ & $15-21 \times 5-6$ & 1-septate & Lacking sheath & $\begin{array}{l}\text { Yellow brown to reddish- } \\
\text { brown }\end{array}$ \\
\hline H. versicolor ${ }^{\mathrm{g}}$ & $265-510 \times 365-530$ & $137-173 \times 17-12$ & $18-41 \times 6-12$ & 2-3-septate & Lacking sheath & $\begin{array}{l}\text { Central cells are pale brown } \\
\text { to dark brown, end cells } \\
\text { hyaline }\end{array}$ \\
\hline
\end{tabular}

${ }^{\mathrm{a}}$ Crous et al. 2018, ${ }^{\mathrm{b}} \mathrm{Su}$ et al. 2016, ${ }^{\mathrm{c}}$ Devadatha et al. 2020, ${ }^{\mathrm{d} D a y a r a t h n e ~ e t ~ a l . ~ 2018, ~}{ }^{\mathrm{e}}$ This study, ${ }^{\mathrm{f}} \mathrm{Hyde}$ et al. 2016, ${ }^{\mathrm{g}} \mathrm{Calabon}$ et al. 2021a

\section{Acknowledgements}

This research work was partially supported by Chiang Mai University. Kevin D. Hyde thanks Chiang Mai University for the award of Visiting Professor. Li Lu thanks the Mae Fah Luang University for the award of a fee-less scholarship and Center for Mountain Futures, Kunming Institute of Botany, Chinese Academy of Science and Center of Excellence in Fungal Research for the facilities provided for her Ph.D. Saowaluck Tibpromma would like to thank the International Postdoctoral Exchange Fellowship Program (number Y9180822S1), CAS President's International Fellowship Initiative (PIFI) (number 2020PC0009), China Postdoctoral Science Foundation, and the Yunnan Human Resources and Social Security Department Foundation for funding her postdoctoral research. Chayanard Phukhamsakda would like to thank National Natural Science Foundation of China (NSFC) for granted a Youth Science Fund Project (number 3210010606). Collecting trips of Vladimír Antonín to South Korea were supported by project FP0801-2010-01 and FP0801-2018-01 of the National Institute of Forest Science in South Korea, and his laboratory studies were funded through the institutional support of long-term conceptual development of research institutions provided by the Ministry of Culture (ref. MK000094862). 


\section{References}

Alexopoulos CJ, Mims CW, Blackwell M. 1996 - Introductory Mycology, $4^{\text {th }}$ edn. Wiley, New York.

Antonín V, Hofstetter V, Ryoo R, Ka K-H, Buyck B. 2017 - New Cantharellus species from the Republic of Korea. Mycological Progress 16, 753-759.

Baldauf SL, Palmer JD. 1993 - Animals and fungi are each other's closest relatives: congruent evidence from multiple proteins. Proceedings of the National Academy of Sciences of the United States of America 90, 11558-11562.

Barr ME. 1984 - Herpotrichia and its segregates. Mycotaxon 20, 1-38.

Blackwell M. 2011 - The fungi: 1, 2, 3. 5.1 million species? American Journal of Botany 98, 426438.

Buyck B, Hofstetter V, Ryoo R, Ka K-H, Antonín V. 2020a - New Cantharellus species from South Korea. MycoKeys 76, 31-47.

Buyck B, Ndolo Ebika ST, De Kesel A, Hofstetter V. 2020b. - Tropical African Cantharellus Adans.: Fr. (Hydnaceae, Cantharellales) with lilac-purplish tinges revisited. Cryptogamie, Mycologie 41, 161-177.

Calabon MS, Jones EG, Boonmee S, Doilom M et al. 2021b - Five novel freshwater ascomycetes indicate high undiscovered diversity in lotic habitats in Thailand. Journal of Fungi 7, e117.

Calabon MS, Jones EG, Hyde KD, Boonmee S et al. 2021a - Phylogenetic assessment and taxonomic revision of Halobyssothecium and Lentithecium (Lentitheciaceae, Pleosporales). Mycological Progress 20, 701-720.

Cao ZM, Li ZQ. 1999 - Rust Fungi of Qinling Mountains. China Forestry Publishing House

Cao ZM, Li ZQ, Zhuang JY. 2000 - Uredinales from the Qinling mountains. I. Mycosystema 19, $13-23$.

Chen CY, Hsieh WH. 2004 - Byssosphaeria and Herpotrichia from Taiwan, with notes on the taxonomic relationship between these two genera. Sydowia 56, 24-38.

Chen MM. 2002 - Forest fungi phytogeography: Forest fungi phytogeography of China, North America, and Siberia and international quarantine of tree pathogens. Pacific Mushroom Research and Education Center, Sacramento, California, USA

Chomnunti P, Hongsanan S, Aguirre-Hudson B, Tian Q et al. 2014 - The sooty moulds. Fungal Diversity 66, 1-36.

Crous PW, Groenewald JZ, Wingfield MJ. 2006 - Anthostomella eucalyptorum. Fungal Planet. no. 1. [https://www.fungalplanet.org/content/descriptions/citations_001.htm]

Crous PW, Wingfield MJ, Burgess TI, Hardy GEStJ et al. 2018 - Fungal Planet description sheets: 716-784. Persoonia 40, 240-393.

Darriba D, Taboada GL, Doallo R, Posada D. 2012 - jModelTest 2: more models, new heuristics and parallel computing. Nature Methods 9: 772.

Dayarathne MC, Wanasinghe DN, Jones EBG, Chomnunti P, Hyde KD. 2018 - A novel marine genus, Halobyssothecium (Lentitheciaceae) and epitypification of Halobyssothecium obiones comb. Nov. Mycological Progress 17, 1161-1171.

De Souza CAF, Lima DX, da Costa DP, da Lima CLF et al. 2020 - Mucor variicolumellatus L. Wagner \& G. Walther (Mucorales, Mucoromycota): a first record for the Neotropics. Check List 16, 743-747.

Devadatha B, Calabon MS, Abeywickrama PD, Hyde KD, Jones EBG. 2020 - Molecular data reveals a new holomorphic marine fungus, Halobyssothecium estuariae, and the asexual morph of Keissleriella phragmiticola. Mycology 11, 167-183.

Dios M, Moreno G, Altes A. 2002 - Dictyocephalos attenuatus (Agaricales, Phelloriniaceae) new record from Argentina. Mycotaxon 84, 265-270.

Dong W, Wang B, Hyde KD, McKenzie EHC et al. 2020 - Freshwater Dothideomycetes. Fungal Diversity 105, 319-575. 
Ekanayaka AH, Ariyawansa HA, Hyde KD, Jones EB et al. 2017 - Discomycetes: the apothecial representatives of the phylum Ascomycota. Fungal Diversity 87, 237-298.

Fan L. 2005 - Phellorinia Berk. In: Symposium on mycology on both sides of the Straits.

Fan L, Liu B. 2004 - A new record genus of Phelloriniaceae from China. Mycosystema 023, 306-307.

Felsenstein J. 1985 - Confidence intervals on phylogenetics: an approach using bootstrap. Evolution 39, 783-791.

Glass NL, Donaldson GC. 1995 - Development of primer sets designed for use with the PCR to amplify conserved genes from filamentous ascomycetes. Applied and Environmental Microbiology 61, 1323-1330.

Griffith GW, Baker S, Fliegerova K, Liggenstoffer A et al. 2010 - Anaerobic fungi: Neocallimastigomycota. IMA Fungus 1, 181-185.

Index Fungorum. 2021 - http://www.indexfungorum.org/Names/Names.asp (Accessed on June 29, 2021).

Hall T. 2005 - BioEdit: biological sequence alignment editor for Win95/98/nT/2K/XP. Ibis Therapeutic, Carlsbad

Hawksworth DL. 1991 - The fungal dimension of biodiversity: magnitude, significance, and conservation. Mycological Research 95, 641-655.

Hawksworth DL. 2001 - The magnitude of fungal diversity: the 1.5 million species estimate revisited. Mycological Research 105, 1422-1432

Hawksworth DL. 2012 - Global species numbers of fungi: are tropical studies and molecular approaches contributing to a more robust estimate? Biodiversity and Conservation 21, 24252433.

Hawksworth DL, Lucking R. 2017 - Fungal diversity revisited: 2.2 to 3.8 million species. Microbiology Spectrum 5, 79-95.

Hibbett DS, Binder M, Bischoff J, Blackwell M et al. 2007 - A higher-level phylogenetic classification of the Fungi. Mycological Research 111, 509-547.

Hillis DM, Bull JJ. 1993 - An empirical test of bootstrapping as a method for assessing confidence in phylogenetic analysis. Systematic Biology 42,182-192.

Hongsanan S, Hyde KD, Phookamsak R, Wanasinghe DN et al. 2020 - Refined families of Dothideomycetidae and Pleosporomycetidae. Mycosphere 11, 1553-2107.

Hongsanan S, Maharachchikumbura SS, Hyde KD, Samarakoon MC et al. 2017 - An updated phylogeny of Sordariomycetes based on phylogenetic and molecular clock evidence. Fungal Diversity 84, 25-41.

Huhndorf SM. 1992 - Neotropical Ascomycetes 2. Hypsostroma, a new genus from the Dominican Republic and Venezuela. Mycologia 84, 750-758.

Hyde KD, Bussaban B, Paulus B, Crous PW et al. 2007 - Diversity of saprobic microfungi. Biodiversity and Conservation 16, 7-35.

Hyde KD, Hongsanan S, Jeewon R, Bhat DJ et al. 2016 - Fungal diversity notes 367-490: taxonomic and phylogenetic contributions to fungal taxa. Fungal Diversity 80, 1-270.

Hyde KD, Maharachchikumbura SS, Hongsanan S, Samarakoon MC et al. 2017 - The ranking of fungi: a tribute to David L. Hawksworth on his 70th birthday. Fungal Diversity 84, 1-23.

Hyde KD, Norphanphoun C, Chen J, Dissanayake AJ et al. 2018 - Thailand's amazing diversity up to $96 \%$ of fungi in northern Thailand are novel. Fungal Diversity 93, 215-239.

Hyde KD, Xu J, Rapior S, Jeewon R et al. 2019a - The amazing potential of fungi: 50 ways we can exploit fungi industrially. Fungal Diversity 97, 1-136.

Hyde KD, Danushka S, Tennakoon DS, Jeewon R et al. 2019b - Fungal diversity notes 1036-1150: taxonomic and phylogenetic contributions on genera and species of fungal taxa. Fungal Diversity 96, 1-242.

Hyde KD, Jeewon R, Chen YJ, Bhunjun CS et al. 2020a - The numbers of fungi: is the descriptive curve flattening? Fungal Diversity 103, 219-271. 
Hyde KD, Dong Y, Phookamsak R, Jeewon R et al. 2020b - Fungal diversity notes 1151-1276: taxonomic and phylogenetic contributions on genera and species of fungal taxa. Fungal Diversity 100, 5-277.

Hyde KD, de Silva NI, Jeewon R, Bhat DJ et al. 2020c - AJOM new records and collections of fungi: 1-100. Asian Journal of Mycology 3, 22-294.

Jaklitsch WM, Gardiennet A, Voglmayr H. 2016 - Resolution of morphology-based taxonomic delusions: Acrocordiella, Basiseptospora, Blogiascospora, Clypeosphaeria, Hymenopleella, Lepteutypa, Pseudapiospora, Requienella, Seiridium and Strickeria. Persoonia 37, 82-105.

James TY, Berbee ML. 2012 - No jacket required - new fungal lineage defies dress code. BioEssays 34:94-102.

Jayasiri SC, Hyde KD, Ariyawansa HA, Bhat DJ et al. 2015 - The Faces of Fungi database: fungal names linked with morphology, phylogeny and human impacts. Fungal Diversity 74, 3-18.

Jeewon R, Hyde KD. 2016 - Establishing species boundaries and new taxa among fungi: recommendations to resolve taxonomic ambiguities. Mycosphere 7, 1669-1677.

Katoh K, Standley DM. 2013 - MAFFT: multiple sequence alignment software version 7: improvements in performance and usability. Molecular Biology and Evolution 30, 772-780.

Kirk PM, Cannon PF, Minter DW, Stalpers JA. 2008 - Dictionary of the Fungi (10th ed.). Wallingford: CABI. p. 679.

Kreisel H, Al-Fatimi M. 2004 - Basidiomycetes and larger Ascomycetes from Yemen. Feddes Repertorium 115, 547-561.

Lange L. 2014 - The importance of fungi and mycology for addressing major global challenges. IMA fungus 5, 463-471.

Lima DX, Souza de Carlos AF, de Oliveira RJV, Luiz BJ et al. 2018 - Mucor irregularis, a first record for South America. Mycotaxon 133, 429-438.

Liu F, Bonthond G, Groenewald JZ, Cai L, Crous PW. 2019 - Sporocadaceae, a family of coelomycetous fungi with appendage-bearing conidia. Studies in Mycology 92, 287-415.

Liu JK, Hyde KD, Jones EBG, Ariyawansa HA et al. 2015 - Fungal diversity notes 1-110: taxonomic and phylogenetic contributions to fungal species. Fungal Diversity 72, 1-197.

Liu YJ, Whelen S, Hall BD. 1999 - Phylogenetic relationships among ascomycetes: evidence from an RNA polymerase II subunit. Molecular Biology and Evolution 16, 1799-1808.

Long WH, Plunkett O. 1940 - Studies in the Gasteromycetes. I. The Genus Dictyocephalos. Mycologia 32, 696-709

Luo ZL, Hyde KD, Liu JKJ, Maharachchikumbura SS et al. 2019 - Freshwater Sordariomycetes. Fungal Diversity 99, 451-660.

Manamgoda DS, Cai L, McKenzie EHC, Crous PW et al. 2012 - A phylogenetic and taxonomic reevaluation of the Bipolaris - Cochliobolus - Curvularia Complex. Fungal Diversity 56, 131144.

Martín M, Hidalgo E, Altés A, Moreno G. 2000 - Phylogenetic relationships in Phelloriniaceae (Basidiomycotina) based on ITS rDNA sequence analysis. Cryptogamie Mycologie 21, 3-12.

Meyer V, Basenko EY, Benz JP, Braus GH et al. 2020 - Growing a circular economy with fungal biotechnology: a white paper. Fungal Biology and Biotechnology 7, e5.

Mindell DP. 2013 - The tree of life: metaphor, model, and heuristic device. Systematic Biology 62, 479-489.

Mugambi GK, Huhndorf SM. 2009 - Molecular phylogenetics of Pleosporales: Melanommataceae and Lophiostomataceae re-circumscribed (Pleosporomycetidae, Dothideomycetes, Ascomycota). Studies in mycology 64, 103-121.

O’Donnell K, Cigelnik E. 1997 - Two divergent intragenomic rDNA ITS2 types within a monophyletic lineage of the fungus Fusarium are nonorthologous. Molecular Phylogenetics and Evolution 7, 103-116.

O’Donnell K, Kistler HC, Cigelnik E, Ploetz RC. 1998 - Multiple evolutionary origins of the fungus causing Panama disease of banana: concordant evidence from nuclear and 
mitochondrial gene genealogies. Proceedings of the National Academy of Sciences of the United States of America 95, 2044-2049.

Page RDM. 1996 - Treeview: application to display phylogenetic trees on personal computers. Computer Applications in the Biosciences 12, 357-358.

Parfrey LW, Lahr DJG, Knoll AH, Katz LA. 2011 - Estimating the timing of early eukaryotic diversification with multigene molecular clocks. Proceedings of the National Academy of Sciences of the United States of America 108, 13624-13629.

Petersen RH, Hughes K. 2012 - The "Big Ditch" project: trans-Atlantic mushroom disjunction tested using multiple taxonomic tools. Inoculum 63, 37-38.

Rambaut A. 2012 - FigTree version 1.4.0. http://tree.bio.ed.ac.uk/software/figtree/ (Accessed on Jan 2021).

Rashmi M, Kushveer JS, Sarma VV. 2019 - A worldwide list of endophytic fungi with notes on ecology and diversity. Mycosphere 10, 798-1079.

Ronquist F, Teslenko M, van der Mark P, Ayres DL et al. 2012 - MrBayes 3.2: efficient Bayesian phylogenetic inference and modelchoice across a large model space. Systematic Biology 61, 539-542

Senanayake IC, Rathnayaka AR, Marasinghe DS, Calabon MS et al. 2020 - Morphological approaches in studying fungi: collection, examination, isolation, sporulation and preservation. Mycosphere 11, 2678-2754.

Stamatakis A. 2014 - RAxML version 8: a tool for phylogenetic analysis and post-analysis of large phylogenies. Bioinformatics 30, 1312-1313.

Su HY, Luo ZL, Liu XY, Su XJ et al. 2016 - Lentithecium cangshanense sp. nov. (Lentitheciaceae) from freshwater habitats in Yunnan Province, China. Phytotaxa 267, 61-69.

Su HY, Udayanga D, Luo ZL, Manamgoda DS et al. 2015 - Hyphomycetes from aquatic habitats in Southern China: Species of Curvularia (Pleosporaceae) and Phragmocephala (Melannomataceae). Phytotaxa 226, 201-216.

Sung G, Hywel-Jones NL, Sung JM, Luangsa-Ard JJ et al. 2007 - Phylogenetic classification of Cordyceps and the clavicipitaceous fungi. Studies in Mycology 57, 5-59.

Swofford DL. 2002 - PAUP*: phylogenetic analysis using parsimony (* and other methods). Version 4.0b10. Sinauer Associates, Sunderland.

Tai FL. 1979 - Sylloge Fungorum Sinicorum. Sci. Press, Acad. Sin., Peking

Tanaka K, Hirayama K, Yonezawa H, Sato G et al. 2015 - Revision of the Massarineae (Pleosporales, Dothideomycetes). Studies in Mycology 82, 75-136.

Tanaka K, Hosoya T. 2006 - Some new records of Loculoascomycetes from Yakushima Island, southern Japan. Bulletin of the National Science Museum, Series B (Botany) 32, 151-160.

Tanney JB, Renaud JB, Miller JD, McMullin DR. 2018 - New 1, 3-benzodioxin-4-ones from Synnemapestaloides ericacearum sp. nov., a biosynthetic link to remarkable compounds within the Xylariales. PloS One 13, e0198321.

Taylor JW, Turner E, Townsend JP, Dettman JR, Jacobson D. 2006 - Eukaryotic microbes, species recognition and the geographic limits of species: examples from the kingdom Fungi. Philosophical Transactions of the Royal Society B-Biological Sciences 361, 1947-1963.

Taylor TN, Krings M, Taylor EL. 2014 - Fossil fungi. Academic Press, London.

Tedersoo L, Sánchez-Ramírez S, Kõljalg U, Bahram M et al. 2018 - High-level classification of the Fungi and a tool for evolutionary ecological analyses. Fungal Diversity 90, 135-159.

Thambugala KM, Hyde KD, Tanaka K, Tian Q et al. 2015 - Towards a natural classification and backbone tree for Lophiostomataceae, Floricolaceae, and Amorosiaceae fam. nov. Fungal Diversity 74, 199-266.

Thompson JD, Gibson TJ, Plewniak F, Jeanmougin F, Higgins DG. 1997 - The Clustal X windows interface: flexible strategies for multiple sequence alignment aided by quality analysis tools. Nucleic Acid Research 24, 4876-4882. 
Tian Q, Liu JK, Hyde KD, Wanasinghe DN et al. 2015 - Phylogenetic relationships and morphological reappraisal of Melanommataceae (Pleosporales). Fungal Diversity 74, 267324.

Van Vooren N, Carbone M, Sammut C, Grupe AC. 2019 - Preliminary notes on the genus Tarzetta (Pezizales) with typifications of some species and description of six new species. Ascomycete.org 11, 309-334.

Vilgalys R, Hester M. 1990 - Rapid genetic identification and mapping of enzymatically amplified ribosomal DNA from several Cryptococcus species. Journal of Bacteriology 172, 4238-4246.

Voglmayr H, Aguirre-Hudson MB, Wagner HG, Tello S, Jaklitsch WM. 2019 - Lichens or endophytes? The enigmatic genus Leptosillia in the Leptosilliaceae fam. nov. (Xylariales), and Furfurella gen. nov. (Delonicicolaceae) Persoonia 42, 228-260.

Wagner L, Stielow JB, de Hoog GS, Bensch K et al. 2020 - A new species concept for the clinically relevant Mucor circinelloides complex. Persoonia - Molecular Phylogeny and Evolution of Fungi 44, 67-97.

Wanasinghe DN, Jones EBG, Camporesi E, Boonmee S et al. 2014 - An exciting novel member of Lentitheciaceae in Italy from Clematis Vitalba. Cryptogamie Mycologie 35, 323-337.

Webster J, Weber R. 2007 - Introduction to Fungi. Cambridge University Press, New York

White TJ, Bruns T, Lee S, Taylor J. 1990 - Amplification and direct sequencing of fungal ribosomal RNA genes for phylogenetics. In: Innis MA, Gelfand DH, Sninsky JJ, White TJ (eds) PCR protocols: a guide to methods and applications. Academic Press, San Diego, pp 315-322.

Willis KJ. 2018 - State of the World's Fungi 2018, Royal Botanic Gardens, Kew.

Wijayawardene NN, Pawłowska J, Letcher PM, Kirk PM et al. 2018 - Notes for genera: basal clades of Fungi (including Aphelidiomycota, Basidiobolomycota, Blastocladiomycota, Calcarisporiellomycota, Caulochytriomycota, Chytridiomycota, Entomophthoromycota, Glomeromycota, Kickxellomycota, Monoblepharomycota, Mortierellomycota, Mucoromycota, Neocallimastigomycota, Olpidiomycota, Rozellomycota and Zoopagomycota). Fungal Diversity 92, 43-129.

Wijayawardene NN, Hyde KD, Al-Ani LKT, Tedersoo L et al. 2020 - Outline of Fungi and fungus-like taxa. Mycosphere 11, 1060-1456.

Yadav AN. 2019 - Fungal white biotechnology: conclusion and future prospects. In Yadav AN, Singh S, Mishra S, Gupta A. (eds.), Recent Advancement in White Biotechnology Through Fungi: vol 3: Perspective for Sustainable Environments. Springer International Publishing, Cham, pp. 491-498.

Yousaf N, Niazi AR, Khalid AN. 2012 - New records of noteworthy gasteroid fungi from Pakistan. Mycotaxon 119, 261-267.

Zhang Y, Schoch CL, Fournier J, Crous PW et al. 2009b - Multi-locus phylogeny of Pleosporales: a taxonomic, ecological and evolutionary reevaluation. Studies in Mycology 64, 85-102.

Zhang Y, Wang HK, Fournier J, Crous PW et al. 2009a - Towards a phylogenetic clarification of Lophiostoma/Massarina and morphologically similar genera in the Pleosporales. Fungal Diversity 38, 225-251.

Zhuang WY. 2005 - Fungi of northwestern China. Mycotaxon, Ltd., Ithaca, New York.

Zhuang WY. 2014 - Flora Fungorum Sinicorum. Volume 48 Pyronemataceae. Science Press, Beijing 